Ivonete Medianeira Pinto

Close-up - A invenção do real em Abbas Kiarostami

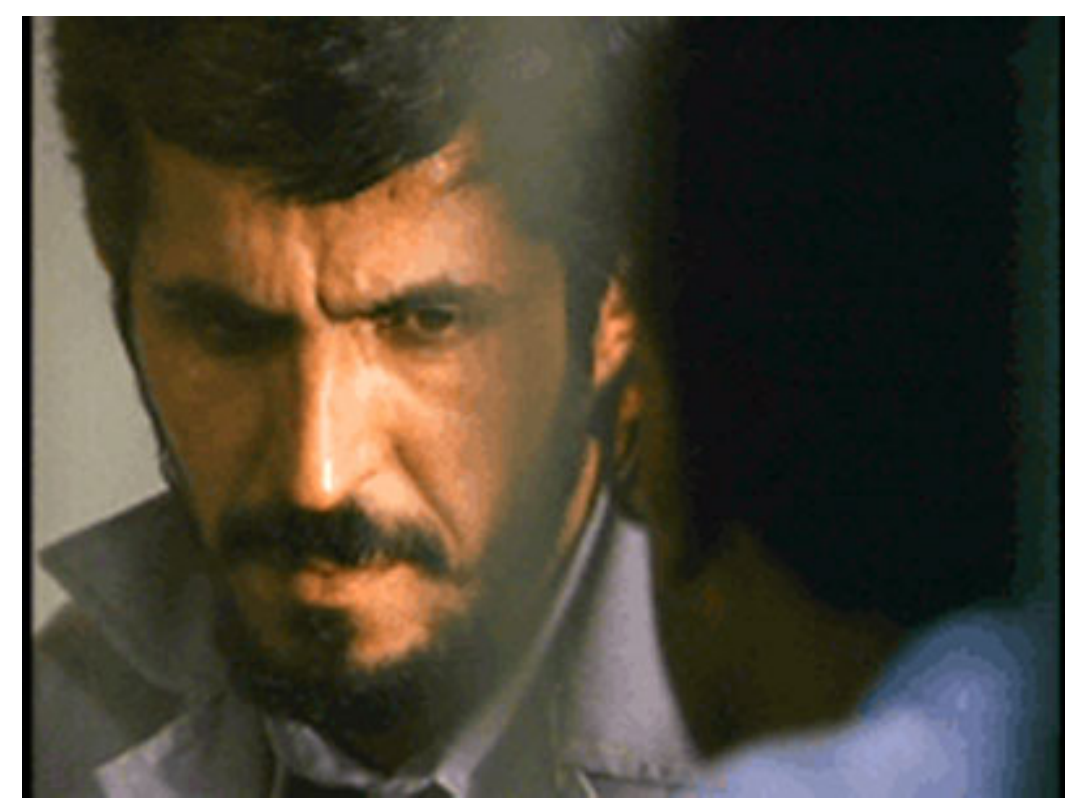

Tese apresentada à Área de Concentração: Estudo dos Meios e da Produção Mediática da Escola de Comunicações e Artes da Universidade de São Paulo, como exigência parcial para a obtenção do Título de Doutor em Ciências da Comunicação, sob a orientação do Prof. Dr. Jean-Claude Bernardet.

SÃO PAULO 
Ivonete Medianeira Pinto

\title{
Close-up - A invenção do real em Abbas Kiarostami
}

\author{
Tese apresentada à Área de Concentração: Estudo dos \\ Meios e da Produção Mediática da Escola de \\ Comunicações e Artes da Universidade de São Paulo, \\ como exigência parcial para a obtenção do Título de \\ Doutor em Ciências da Comunicação, sob a orientação do \\ Prof. Dr. Jean-Claude Bernardet.
}

SÃO PAULO

2007 
BANCA EXAMINADORA 



\section{Agradecimentos:}

Às funcionárias da secretaria da ECA, pela gentileza.

Aos amigos, Mehran, Hamid, Carla Saueressig, Glênio Póvoas, Cláudia Antonini e Rejane Fernandes, pelo incentivo.

Aos jornalistas Faysal Abdullah, Amin Farzanefar e Shadi Fakih pelas conversas produtivas no festival de cinema de Teerã.

Ao embaixador do Irã em Brasília, Mansour Moazami, e ao embaixador do Brasil em Teerã, Cesário Melantônio, pelo apoio.

Aos cineastas iranianos Bahman Ghobadi, Jafar Panahi, Hasan Yektapanah e Tahmineh Milani, pelas entrevistas.

Ao diretor de assuntos internacionais da Farabi Cinema Foundation, Amir Esfandiari, pela disponibilização de filmes.

Aos professores Jamil Ibrahim Iskandar, pela leitura do texto e correções, Marco Lucchesi e Miguel Attie Filho, pelas indicações.

À professora Beatriz Fontana pela tradução da intrincada frase de Jerry Kuehl. 
Aos professores Eduardo Santos Mendes e Paulo Menezes pelas sugestões no processo de Qualificação.

Ao professor Ismail Xavier pela leitura atenta do trabalho e o estímulo para enfrentar novas abordagens.

Ao meu orientador Jean-Claude Bernardet, por compartilhar sua sabedoria e seu interesse por cinematografias tão distantes (ainda) do universo brasileiro de pesquisa acadêmica.

À família Irma, Glazi, Guinha e Arthur, pela compreensão.

Ao Armando Pierre Gauland, pela companhia em terras persas à procura do “cavalo de Hussein".

E a Mario Pinto, in memoriam. 
Meu amigo, a verdade verdadeira é sempre inverossímel, você sabia? Para tornar a verdade mais verossímel, precisamos necessariamente adicionar-Ihe a mentira. Stiepan Trofímovich (Os Demônios, Fiódor Dostoiévski) 


\section{RESUMO}

\section{Close-up - A invenção do real em Abbas Kiarostami}

A proposta desta tese é apresentar uma análise do filme Close-up, do cineasta iraniano Abbas Kiarostami.

Inicialmente, são expostos dados do universo histórico, religioso e cultural do Irã, relacionando-os ao tema do trabalho. Em seguida, a narrativa de Close-up é analisada sob a perspectiva do cinema documental, onde o referencial teórico utiliza autores da teoria do cinema. As implicações desta narrativa, por sua vez, dão lugar à análise do aspecto ético da obra, quando são trabalhados autores da área da filosofia, com espaço para pensadores que representam a falsafa, a filosofia islâmica.

A presença da ficção nas obras documentais, com foco em Close-up, direciona o estudo para o questionamento dos limites da liberdade do autor quando este, voluntária ou involuntariamente, possa vir a prejudicar os indivíduos apresentados nos filmes. Neste sentido, em especial dois procedimentos de Kiarostami são investigados: o que manipula, através da montagem, a presença de um juiz no tribunal, e o que manipula, através da edição do som, um diálogo entre Hussein Sabzian e Mohsen Makhmalbaf. Procedimentos estes pelos quais se pretende problematizar a intervenção/ficcionalização dos cineastas em filmes com estrato documental.

\section{Palavras-chave}

Abbas Kiarostami, Irã, Cinema, Documentário, Realismo, Filosofia 


\section{ABSTRACT \\ Close-up - The real's invention on Abbas Kiarostami}

The purpose of this dissertation is to present the analysis of the film Close-up, directed by the Iranian filmmaker Abbas Kiarostami.

At first, data from the historic, religious and cultural Iranian universe are explained, relating them to the study's theme. After that, an analysis of the movie's narrative is considered in the perspective of documental cinema, and according to the cinema theory. The narrative implications give rise to the analysis of the ethic aspects of the movie, as philosophers that represent the falsafa, the Islamic philosophy, are taken into account.

The presence of fiction in documental works, as in Close-up, puts the focus of this study in the questioning of the author's freedom limits, as he deliberately or not could cause damage to the people shown in the movie. Due to that, two procedures performed by Kiarostami are especially investigated: the one that manipulates, through the film editing, the presence of a judge at a court trial, and the one that manipulates, through the sound editing, a dialogue between Hussein Sabzian and Mohsen Makhmalbaf. These procedures will be analyzed in order to problematize the filmakers'intervention/fictionalization of documental movies.

\section{Key Words}

Abbas Kiarostami, Iran, Cinema, Documentary, Realism, Philosophy 


\section{Nota sobre estilo e tradução}

Optou-se aqui por manter os títulos dos filmes iranianos lançados no Brasil em português, mesmo que só em festivais, e em inglês quando inéditos no circuito comercial e em vídeo. Nos dois casos os títulos são seguidos do original em farsi. A primeira menção de um filme vem acompanhada do título no original e da data de produção. Citações em inglês, espanhol e francês foram traduzidas pela autora.

O processo de transliteração dos termos em árabe e farsi adota uma versão simplificada do International Journal of Middle East Studies. Para facilitar a leitura, o plural das palavras árabes é feito adicionando um "s" às mesmas e não segundo as regras da gramática árabe. 


\section{SUMÁRIO}

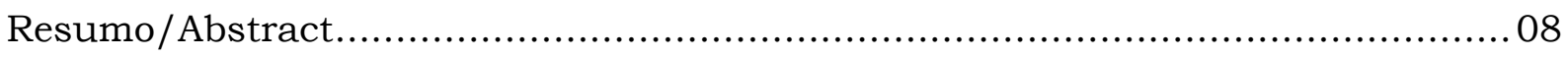

Nota sobre estilo e tradução ................................................................. 10

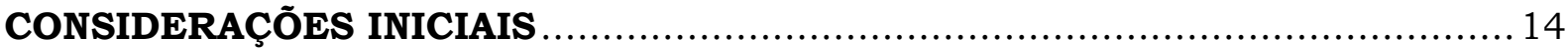

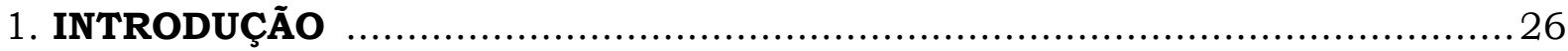

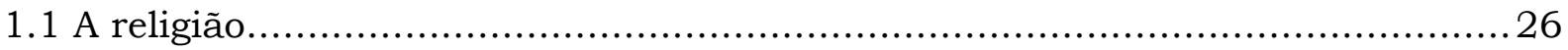

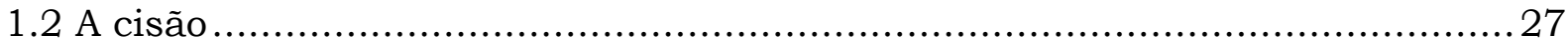

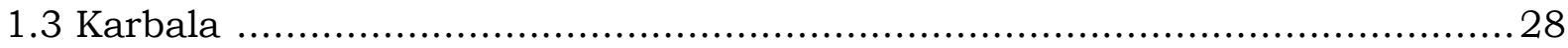

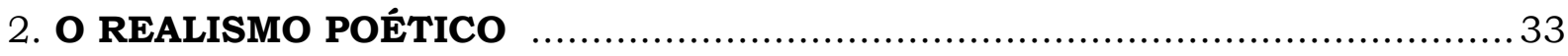

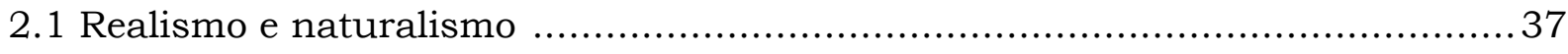

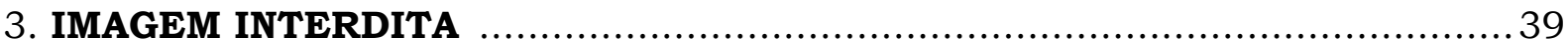

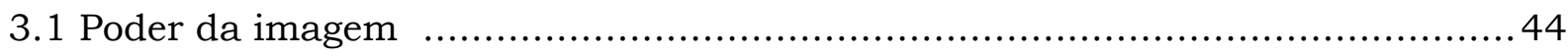

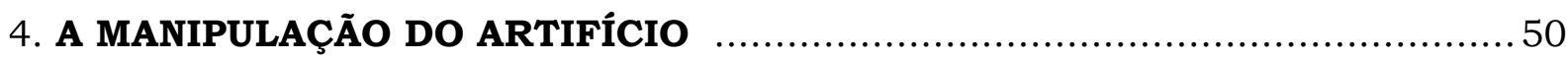

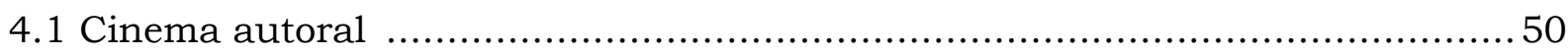

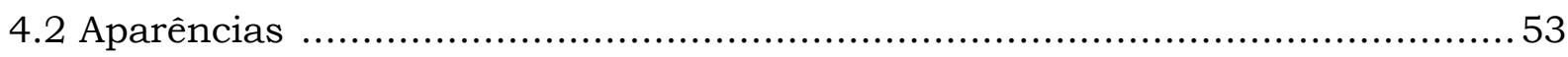

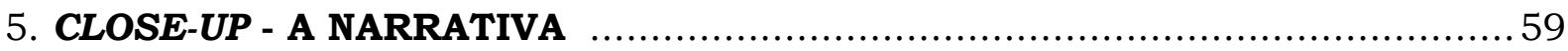

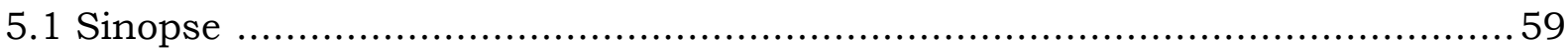

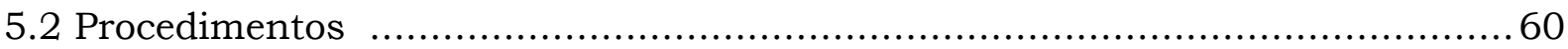

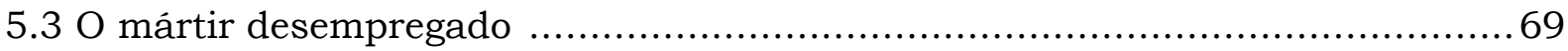

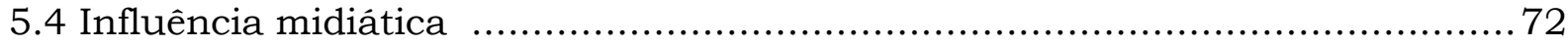

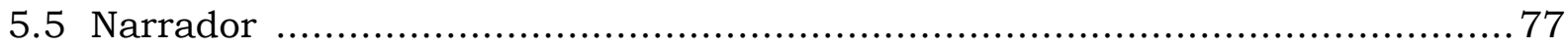

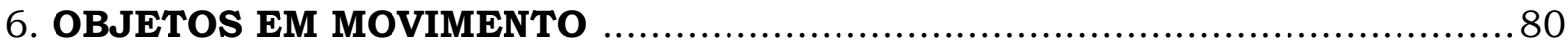

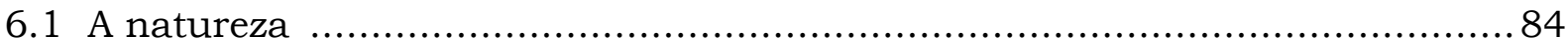

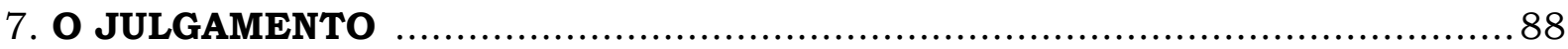

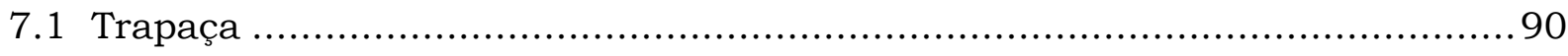




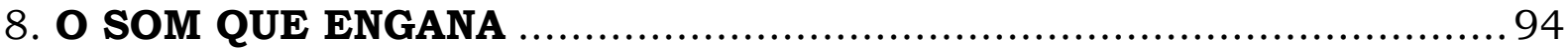

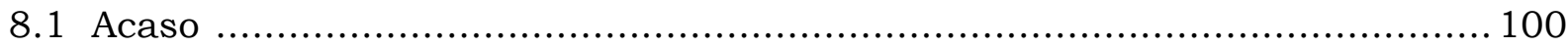

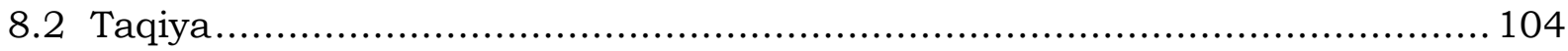

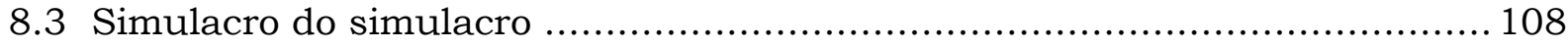

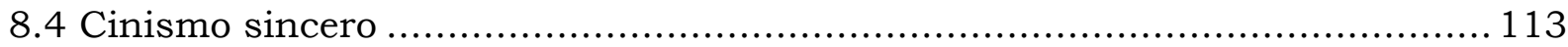

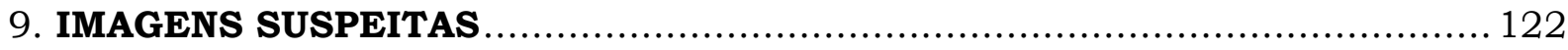

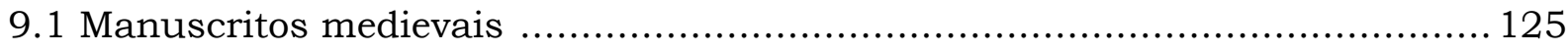

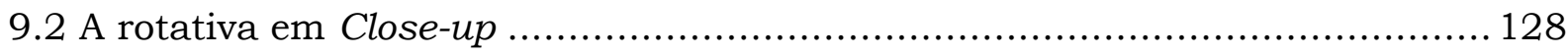

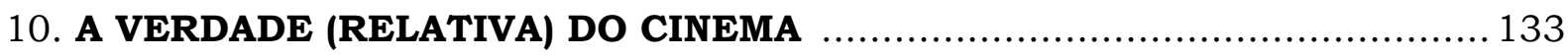

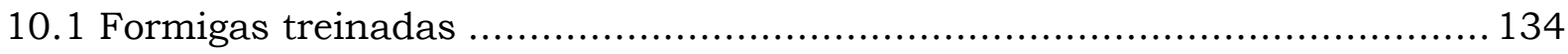

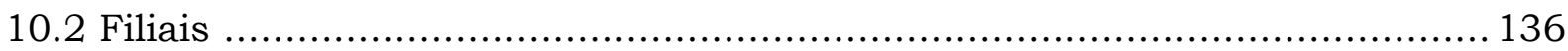

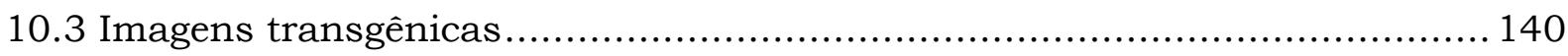

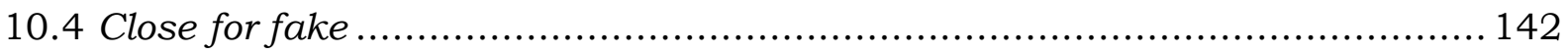

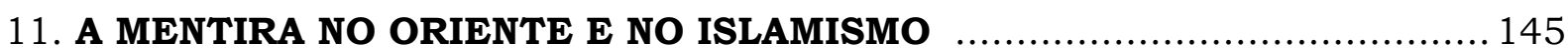

12. A MENTIRA NA FILOSOFIA (OCIDENTAL) ................................... 148

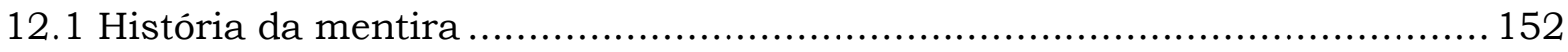

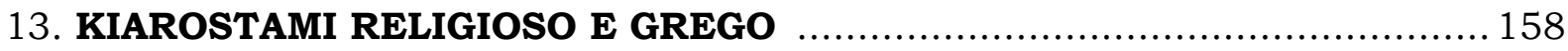

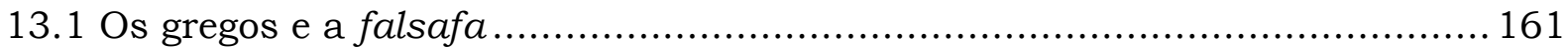

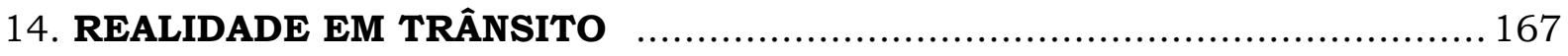

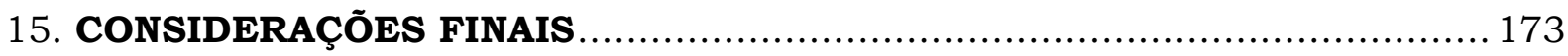

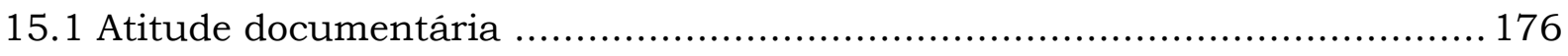

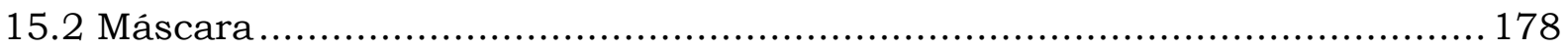

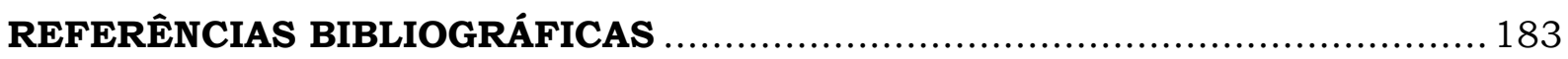

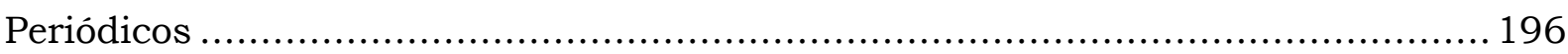

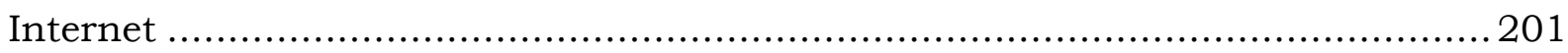


FILMES SOBRE KIAROSTAMI UTILIZADOS PARA O PROJETO 205 ANEXOS 206

1. DESCRIÇÃO comentada do filme Close-up Long Shot ...............................206

2. FILMOGRAFIA de Abbas Kiarostami como diretor ................................. 208

3. FILMOGRAFIA de Abbas Kiarostami apenas como roteirista $\ldots \ldots \ldots \ldots \ldots \ldots \ldots \ldots . \ldots . \ldots . \ldots . \ldots 212$

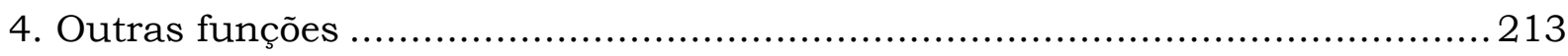




\section{Considerações iniciais}

Enquanto o Irã é sistematicamente demonizado pelas grandes potências, com reforço da retórica anti-ocidental por parte do atual presidente Mahmoud Ahmadinejad, o cinema iraniano segue produzindo filmes artisticamente instigantes. Com o uso deste termo (artisticamente), já demarcamos o território abarcado neste trabalho. Ou seja, esta reflexão procurará desviar-se do eixo exotismo-interdição que costuma ser superdimensionado nas análises sobre os cineastas iranianos e, muitas vezes, equivocado quando se trata de Abbas Kiarostami. O cinema deste diretor está na ordem da filosofia, das artes plásticas e da poesia, numa perspectiva universal e, portanto, enquadrá-lo num sistema de circunstâncias, como a censura vigente em seu país, tema de grande parte dos estudos sobre o cinema iraniano, seria limitar a possibilidade de compreensão da sua obra.

Buscando localizar o que podemos chamar de a "dimensão essencial" de Kiarostami, nos domínios do cinema, esta investigação volta-se para o campo teórico que envolve as relações entre verdadeiro versus falso no âmbito da não-ficção. Descrevendo e interpretando como método de base, procuramos fazer com que a teoria possa surgir da análise do filme aqui trabalhado e não o contrário.

Assim sendo, este trabalho analisa o cinema de Kiarostami quanto ao estatuto da representação fílmica (verdadeiro versus falso), tendo como recorte principal o título 
Close-up (Namay-e Nazdik, 1990), cujo valor estético, filosófico e social pretendemos demonstrar. Nossa hipótese é de que Close-up, especialmente nas cenas aqui denominadas "Julgamento" e "O som que engana", coloca Kiarostami na posição de quem foi além da modernidade, como definiu Youssef Ishaghpour.

A ambigüidade de sua natureza leva Close-up a aparecer em ensaios críticos, tanto os jornalísticos quanto os acadêmicos, como documentário, não-ficção, ficção, "doc-fic" e, algumas vezes, como "docudrama". O filme, nos parece, presta-se ao vocábulo "docfic", cuja paternidade é atribuída ao argentino Fernando Birri, significando a mistura entre documentário e ficção ${ }^{1}$. E presta-se ao termo "docudrama" para expressar a dramatização de fatos acontecidos, apesar de ser considerado pejorativo para alguns documentaristas, pois seria uma imposição terminológica dos americanos. De todo modo, não se trata de uma querela semântica, mas sim de dilema ético, como veremos mais adiante.

Nublando as fronteiras da ficção e da não-ficção, Kiarostami amplia as possibilidades narrativas do cinema e redefine os conceitos em torno do realismo e do próprio real, considerando-se aqui o realismo como produtor de "efeito do real" e o real como "o que existe por si mesmo", idéias desenvolvidas no primeiro capítulo. Ao dificultar a oposição entre documentário e ficção, Kiarostami cria uma outra categoria de cinema.

\footnotetext{
${ }^{1}$ Vladimir Sosa SARAIVA traz a informação de que "doc-fic" foi cunhado como termo pelo amigo de Birri, o brasileiro Orlando Senna. In:Los Medios, La Réplica y los Completos. Site "Los Documentalistas", Buenos Aires, 2005.

(http://www.documentalistas.org.ar/nota-boletin.shtml?sh_itm=b8de57ff60833ca12c40909476c25d82)

${ }^{2}$ Noções defendidas por Jacques AUMONT \& Michel MARIE no Dicionário Teórico e Crítico de Cinema.
} 
A partir das experimentações formais realizadas em Onde Fica a Casa do Meu Amigo? (Jane-ye dust koyast?, 1987) e radicalizadas em Close-up, o diretor iraniano passa a ser referência nuclear, verdadeira matriz para os procedimentos posteriores na esfera de seu próprio cinema e na de outros cineastas. Com intrincadas elaborações em torno do real, Kiarostami estimula a uma reflexão no sentido inverso do que disse André Bazin sobre ter "fé na imagem". Para tanto, nossa postura aqui será a de colocar sob suspeita tudo o que possa parecer espontâneo e real.

Diferente de Wim Wenders em Nick's Movie, Ligthning over water (1980), Kiarostami nem sempre expõe a ficção/encenação. E a lembrança deste filme opera aqui ainda uma outra função: a de trazer à tona o conteúdo moral de Close-up.

Nick's Movie registra os últimos dias do diretor Nicholas Ray, que sofria de câncer. Ismail Xavier abre a edição brasileira de O Cinema - Ensaios, de André Bazin, justamente falando deste filme, onde afirma que, embora a experiência da filmagem tenha ocorrido em comum acordo entre Wenders e Ray, teria havido uma profanação deste momento único do ser humano. A discussão, naturalmente, recai sobre o aspecto moral de uma filmagem que se dá no leito de morte. E o que se poderia questionar em relação a Kiarostami, é como e quanto ele expõe um sujeito absolutamente fragilizado que, embora metaforicamente, também estava morrendo diante da câmera. O que Philippe Dubois chamou de "experiência dos limites"3 em relação a Wenders, chamamos aqui de "invenção do real" e em torno dele refletimos com o apoio de autores da área do cinema e da filosofia (principalmente nos capítulos 11, 12 e 13), esta, aliás, seara pouco explorada nos estudos sobre Kiarostami, em especial sobre Close-up.

\footnotetext{
${ }^{3}$ In: Philippe DUBOIS, Cinema, Video, Godard, p. 126.
} 
Há décadas que os teóricos do cinema abordam o tema da ausência da verdade e o direito que o autor de uma obra tem ou não de faltar com a verdade. O limite, ou o não-limite a que ele está vinculado. A convivência entre o registro documental e a encenação não é algo novo no cinema moderno. Desde os irmãos Lumière, passando por Dziga Vertov, Robert Flaherty e John Grierson, na primeira metade do século; Robert Drew, Richard Leacock, Donn Pennebaker e Jean Rouch, na segunda, trouxeram muitos modos de fazer cinema que buscavam a verdade. Se formos menos ecléticos, podemos até considerar que $A$ Bruxa de Blair (The Blair Witch Project, 1999) ${ }^{4}$ é o cinema-verdade chegando a Hollywood. Neste caso, não pelo conteúdo do filme em si, mas pelo debate sobre a questão da verdade no e do cinema que emergiu dele, atingindo públicos pouco afeitos a este tipo de preocupação.

Depois da A Bruxa de Blair vale registrar outras incursões neste subgênero, o chamado mockumentary (ou mockudomentary) ${ }^{5}$. Incursões, note-se, mais radicais, complexas e nem por isso menos farsescas, como Borat - O Segundo Melhor Repórter do Glorioso País Cazaquistão Viaja À América (Borat - Cultural Learnings of America for Make Benefit Glorious Nation of Kazakhstan, Larry Charles, 2006). O mais intrigante desses filmes, sem dúvida, é Incidente no Lago Ness (Incident at Loch Ness, Zak Penn, 2004), onde Werner Herzog interpreta ele mesmo fazendo um documentário "sério" sobre o lendário monstro. Herzog se prestou a produzir e protagonizar este falso

\footnotetext{
${ }^{4}$ Trata-se de um falso documentário sobre três estudantes que se embrenham na floresta para fazer um documentário sobre estranhos acontecimentos que cercam a cidade americana de Burkittsville. Ao custo de 35 mil dólares, sua produção indigente convenceu uma parcela dos espectadores de que as imagens poderiam ser documentais de fato. Isto, graças a uma campanha promocional que incluía site com testemunho de "especialistas" sobre a bruxa.

${ }^{5}$ Uma lista comentada destes filmes pode ser encontrada no livro Faking it - Mock-Documentary and the Subversion of Factuality, de Jane ROSCOE e Craig HIGHT (Manchester University Press, 2001)
} 
documentário, de maneira extremamente convincente, diga-se, porque seria impensável imaginar que o diretor alemão conhecido pelo realismo obsessivo de suas produções (o barco de Fitzcarraldo, por exemplo, era de tamanho natural e foi de fato transportado por terra, pelos índios) seria capaz de atuar tão bem, de modo tão realista, inclusive nos falsos depoimentos para os "extras" incluídos no filme.

Já o americano Jonathan Caouette partiu de fragmentos de filmes super 8 e vídeos caseiros para realizar a cinebiografia Tarnation (2003), registro doméstico de sua família desde os 11 anos - com ênfase para os distúrbios mentais da mãe e dele próprio. Experiência radicalizada em All Tomorrow's Parties ${ }^{6}$, onde junta imagens de filmes e da internet ao material biográfico, produzindo um emaranhado de reproduções ficionais e não ficcionais. Caouette, com isto, cria um novo tipo de documentário, tornando os filmes de Jonas Mekas (diários filmados de sua vida durante décadas) apenas referência histórica, e Na Captura dos Friedman (Capturing the Friedmans, Andrew Jarecki, 2003), um trabalho apenas relevante pelo seu conteúdo (o abuso sexual contra crianças), já que a sua forma limita-se à narrativa centrada em filmes super 8 registrando cenas domésticas de abusados e abusadores.

Ao trazermos Close-up para o centro da análise, acreditamos estar atualizando a discussão, fazendo emergir possibilidades de interpretação ligadas ao universo cultural de Kiarostami, notadamente o contexto islâmico xiita, sem nos desviarmos do dilema ético em torno da dicotomia verdade-mentira. 
Temos plena consciência que as expressões aqui largamente utilizadas, como verdade e mentira, têm noção abstrata, e formam as grandes questões da filosofia. $\mathrm{O}$ conceito de mentira, por exemplo, é tão flexível filosoficamente (como a epígrafe de Dostoievski), que nos parece mais adequado ao conceito de impostura. A impostura, segundo Houaiss, é "mentira ardilosa". Portanto, resistimos um pouco a usar o termo impostura em relação a Kiarostami e seus artifícios e manipulações. Porém, não seria indicado reduzir as idéias a questões semânticas. De fato, o que se quer discutir aqui é a postura de um diretor que maneja informações oferecendo algo ao espectador com o invólucro de uma coisa e o conteúdo de outra.

Seriam incontáveis as relações que poderíamos fazer sobre a importância de se discutir a mentira na sociedade contemporânea, pois sabemos quão graves implicações podem ter certas mentiras. Basta lembrar o presidente americano Bill Clinton quanto ao affair Monica Lewinsky e sua quase destituição do cargo não pelo affair em si, mas por ter mentido sobre ele. E, mais grave, o presidente George Bush ter mentido quanto à existência de armas nucleares no Iraque $^{7}$ e, com isso, ter invadido o país, provocado milhares de mortes, incluindo o enforcamento do ex-ditador Saddam Hussein, com direito à exibição de imagens pela TV, num digno exemplo da sociedade do espetáculo de que fala Guy Debord.

\footnotetext{
${ }^{6} \mathrm{O}$ longa-metragem será lançado em 2008. O work in progress foi apresentado em Porto Alegre no evento Do Lixo ao Luxo: Hibridismo e Reciclagem Cultural (Sala P.F.Gastal), em maio de 2007.

${ }^{7}$ A expressão "mentira" é utilizada pela imprensa sem eufemismos neste caso, como no texto do cronista Luis Fernando Verissimo intitulado Show, onde ele fala do tradicional jantar anual das associação de correspondentes estrangeiros em Washington, quando o presidente americano faz humor intencional. Em 2006, George Bush apareceia em um vídeo procurando algo embaixo de uma mesa e dizendo "aquelas armas de destruição em massa têm que estar em algum lugar..." (gargalhadas). Verissimo conclui: "O governo acabara de reconhecer que a principal razão para os Estados Unidos invadirem o Iraque, a existência de um arsenal nuclear e químico pronto para ser disparado por Saddam, era falsa. As armas de destruição em massa não tinham sido encontradas, eram parte da grande mentira, da ficção
} 
No âmbito do cinema, a dificuldade deste debate em torno da mentira - e por outro lado, a necessidade dele - cada vez mais se acentua porque soa, por assim dizer, como um direito sagrado que um cineasta possa, em nome da liberdade de criação que a arte pressupõe, jogar com os dados ao seu bel prazer. Por outro lado, teóricos, críticos e até espectadores ficam de mãos amarradas quando o cineasta em questão diz que só tem compromisso com a "verdade do cinema". A ele, as prerrogativas de invenção parecem ilimitadas. Mas e quando este cineasta está lidando com vidas humanas e não simplesmente com o que tecnicamente chamamos de "personagem"? E quando o cineasta estica a montagem para fora do filme, "remontando" em entrevistas a sua versão para determinado procedimento polêmico?

Por estas razões, este trabalho não priscindiu de crises, onde a questão que se impunha era: por que passar quatro anos analisando um filme sob esta perspectiva, se é óbvio que um diretor de cinema, um artista, pode fazer o que bem entender com os recursos técnicos-narrativos de que dispõem? Por que investir neste problema se até o jornalismo pode ser classificado como inventivo? O jornalismo inventivo, que guarda parentesco com o jornalismo literário (ou new journalism), analisado no capítulo 5 , é o campo para as informações inventadas, seja por esquecimento do dado real, seja para estar a favor de algum propósito literário. Estela Canto informa em Borges à Contraluz, que Mario Vargas Lhosa certa vez entrevistou o escritor argentino em seu apartamento em Buenos Aires. Em seu artigo, o escritor peruano afirmava que Borges tinha sobre sua cama um roupão lilás. Segundo Fanny, a governanta de Borges, este "nunca teve um roupão lilás". 8

preparada para justificar o ataque. Àquela altura, quase 2 mil soldados americanos, além de milhares de iraquianos, tinham morrido por causa da mentira." (grifos nossos) In: Zero Hora, 5 abr, 2007, p. 3. 
Em princípio, a cor inventada para o roupão de Borges não o prejudicou. Mas não seria preciso muita imaginação para criar possibilidades de interpretação, inclusive porque lilás é uma cor símbolo da comunidade gay e Borges podia ter ficado realmente descontente. Talvez se lançarmos mão de um exemplo menos frívolo, as conseqüências do jornalismo inventivo ganhe outra dimensão. A repórter Chistiane Amanpour, à época na $\mathrm{BBC}$, quando cobriu a guerra na Bósnia pagava para soldados dispararem tiros próximo do local onde ela gravava as reportagens para que seus boletins tivessem mais atmosfera. $^{9}$

O episódio, relatado por várias pessoas com quem conversamos na Bósnia poucos meses após a guerra (1997), serviu de mote para a emersão das crises de questionamento com o tema até o momento (2007). Além do mais, o real sempre bate à porta através de jornais, revistas, livros, conversas de bar, novelas (os depoimentos para a câmera no final da novela Páginas da Vida, de Manoel Carlos, numa aproximação com o gênero documentário), que conspiram trazendo o assunto à tona: a mistura de realidade e ficção, a subversão de gêneros, o comportamento ético de realizadores, a possibilidade de um filme alterar a realidade... Discussões com alta voltagem de controvérsia, seja no jornalismo, na literatura ou no cinema, alimentadas pela freqüência com que aparecem trabalhos que redefinem o problema, abrem janelas, sulcos, redirecionam os conceitos, embaralham as certezas.

\footnotetext{
${ }^{8}$ In: Estela CANTO, Borges à contraluz, p. 203.

9 "A marca deixada na Bósnia por Christiane Amanpour ficou gravada. Na capital Sarajevo, ou na distante Mostar, no interior, moradores e motoristas de táxi apontam os 'cenários' onde ela, e também outros repórteres em seu rastro, gostavam de gravar os boletins. Estes locais funcionam hoje como se fossem locações de filmes famosos”. In: Ivonete PINTO. A Dramatização no telejornalismo. Dissertação de Mestrado, 1997.
} 
Afora aprofundar esta discussão, acreditamos que o diferencial deste trabalho em relação aos inúmeros textos produzidos sobre Kiarostami, via de regra assinados por europeus, esteja nos detalhes de uma visão que eventualmente conseguiu adentrar a superfície na questão da ética, inserindo-se aí a cultura e a religião daquele País.

Nas três edições do Fajr International Film Festival, de Teerã, além de termos acesso a publicaçõe locais, como a revista Film International - Iranian Film Quarterly, pudemos observar um certo grau de incompreensão dos críticos presentes, incluindo Jonathan Rosembaum e Alberto Elena, que muitas vezes incorrem em mistificações do universo islâmico e da sociedade iraniana, esferas, de resto, indissociáveis. A maior parte destes críticos restringe-se à capital Teerã e à programação oficial do evento. Os que se aventuram a conhecer melhor o país procuram a agência de turismo dentro do próprio hotel, no caso o Laleh, e compram bilhetes para as cidades de Shiraz e Isfahan. Eles visitam em Shiraz o sítio arqueológico da primeira capital do Império Persa, Persépolis, e em Isfahan, a ponte dos 33 arcos, que foi cenário de Pasolini para o seu As Mil e Uma Noites (1974).

Considerando que nas três oportunidades lá (1998-2001-2002) nossos interesses eram mais amplos e incluiam a produção de um livro sobre o Irã, o tempo das viagens foi maior comparado ao tempo investido pelos críticos que cobrem o festival. As amizades e o contato com o interior do país, que não o turístico, foram desta forma de extrema importância. Como conhecer Tabriz, cidade na região do Azerbaijão iraniano, circunstância que nos possibilitou outra leitura da origem do personagem central de Close-up, Sabzian, como desenvolvido no capítulo Close-up - A narrativa. Por outro lado, só no Irã foi possível conhecer uma bibliografia não encontrada no exterior. Na 
cidade de Qom, por exemplo, centro de estudos teológicos onde Khomeini e todo alto clero xiita estudaram, há livrarias com textos em inglês e francês, freqüentadas por estudantes estrangeiros (todos falam árabe, pois que para ler o Corão é preciso conhecer árabe, mas poucos falam farsi). Em Qom encontramos um livro fundamental para entender os preceitos e a hermenêutica do sistema islâmico da sharia ${ }^{10}$, que foi a obra do líder espiritual do Irã, aiatolá Khamenei, como consta na bibliografia.

Também em Qom criaram-se as condições necessárias para o desenvolvimento de uma sensibilidade para as questões místico-religiosas. Lá, no túmulo de Fátima Masumah, irmã de um dos personagens mais venerados da história xiita, o Imã Hussein, os gritos e o choro convulsivo dos fiéis ao tocarem à lápide revestiam-se de uma carga de informação muito maior do que qualquer livro pudesse conter.

Já no Complexo Iman Khomeini, na periferia de Teerã, também ignorado pelos estrangeiros em geral, foi possível a aproximação com a figura mítica e carismática do líder da Revolução Islâmica de 1979. No museu dedicado à sua memória pudemos perceber que o país não se difere de outros do Ocidente quanto ao fascínio pela imagem, como demonstrado no capítulo 5. Neste sentido, ir ao cinema em sessões normais, para iranianos, mesmo necessitando da ajuda de um tradutor de farsi, nos deu outra percepção da produção iraniana que, contrariamente ao que se pensa fora de lá, não está só voltada aos filmes com crianças, que remetem ao neo-realismo italiano. Está voltada sobretudo aos dramas que transitam entre Bollywood e Hollywood.

\footnotetext{
10 A sharia, de onde é baseada a Constituição do Irã desde a Revolução 1979, é o sistema de leis islâmicas que têm como base o Corão. A sharia dita o comportamento individual, a lei penal e pública do país.
} 
Acompanhando in loco a transformação do país nos dois períodos do governo do presidente moderado Mohammad Khatami, observamos uma tendência deste cinema revolucionário - a Revolução Islâmica está em pleno andamento - a enaltecer um tema caro a esta tese, a questão da verdade.

A verdade para o cinema iraniano revolucionário é um princípio. A comprovação desta afirmativa é encontrada na chamada "small media" (música, grafites, cartoons, posters, etc.), que divulga e reforça os valores da Revolução, e ao mesmo tempo revela o grau de consciência da população. Um dos posters da revolução, com frases em farsi e inglês, mostra um cameraman apontando sua lente para uma manifestação de rua (que vemos graças ao reflexo da lente). As frases inscritas conclamam a imprensa e o cinema para que mostrem a realidade como ela realmente é. 11

Na perspectiva do cinema como indústria, o que se pôde notar é a convivência com vários tipos de gênero. Um cinema popular, que reafirma através de vários temas os valores da Revolução, incluindo-se aí os traumas da guerra Irã-Iraque (Kamal Tabrizi); um cinema engajado, que critica a sociedade atual (Jafar Panahi, Tahmineh Milani), e um cinema que por falta de melhor termo chamaremos de "cinema de arte", preocupado com questões universais, estéticas e de linguagem e que, mais do que dar respostas, procura questionar (Abbas Kiarostami). Por sinal, esta foi a impressão que tivemos de Kiarostami nos encontros, tanto em Teerã (Fajr Film Festival) como em São Paulo (Mostra Internacional): um homem que gosta mais de perguntar do que de responder. Que tem o vício de ofício de um documentarista.

\footnotetext{
${ }^{11}$ Este e outros posters são analisados no artigo "Revolutionary Posters and Cultural Signs", por Michael FISCHER \& Mehdi ABEDI. In: Middle East Report. Jul-Ago, 1989, pp.29-32.
} 
Tudo isto gerou um estado lato, propício à uma compreensão um pouco mais aguda do País, embora estejamos certos que, mesmo que o trabalho conte com diversos autores iranianos como apoio, sempre será a visão de um estrangeiro. E, neste caso, vindo de um país tão distante e de inúmeras formas tão diferente como o Brasil.

Portanto, trabalha-se aqui com a consciência de que este texto não deixa de representar uma reflexão orientalista, no sentido que Edward Said dá para orientalismo: uma invenção do Ocidente, produzido por uma tradição acadêmica que herdou desde a Antigüidade a idéia do Oriente como lugar estranho. Enfim, um pensamento sobre o Outro. No dizer de Said, todo orientalismo está fora do Oriente e afastado dele. De quaquer forma, o sentido que se tenta dar a este trabalho, afora o primeiro plano voltado ao estudo do cinema e suas relações com a ética, é o de dar visibilidade a questões ignoradas pela crítica e pela academia ocidentais. Questões estas ligadas à tradição, à cultura e à religião presentes no Irã, que são parte inextricável da obra de Kiarostami. 


\section{1 - Introdução}

Neste capitulo, apresentamos o contexto cultural-religioso em que Kiarostami está inserido, e demonstramos que o fato de ser xiita pode implicar em uma visão de mundo mística, onde a encenação da tragédia de Karbala tem papel relevante.

\subsection{A religião}

Abbas Kiarostami é resultado de uma cultura, mais exatamente da cultura persamuçulmana-xiita. Note-se que se utilizarmos um conceito mais preciso quanto à religião, caberia dizer que ele é muçulmano e não um seguidor do islamismo. O termo islamismo, atualmente, define um forte sentido de militância política, no contexto da Ummah, palavra árabe que significa comunidade, ou nação, e que vem sendo usada para designar a comunidade islâmica mundial.

O Irã é habitado há sete mil anos a.C ${ }^{12}$. As tribos que lá viviam criaram formas de escrita próprias, domesticaram os animais e inventaram sistemas de irrigação. As tribos indo-germânicas - ou os "arianos", de onde vem a raça pura a que Hitler se referia - vindas do Oriente, foram os primeiros invasores que originaram os reinos dos Medas e dos Persas.

\footnotetext{
${ }^{12}$ O nome do país era Pérsia e passou a se chamar oficialmente Irã em 1935. O objetivo de Pahlevi (pai) era reforçar a origem indo-européia, dentro da sua cruzada à modernização forçada inspirada na Turquia. Irã significa "terra dos arianos" (a etimologia vem de "airyano/erãn"). Pérsia (Persis) era o nome de uma tribo ariana da época de Ciro. Os Pahlevi surgem em 1921, quando o general Reza Khan derruba o último
} 
Importante ressaltar que o iraniano não é árabe, como é muito freqüente ser confundido no Ocidente $^{13}$. O islamismo foi introduzido no Irã, então Pérsia, com a invasão dos árabes em 642. Até esta época, o Zoroastro era a religião persa. O país tem sido governado por xiitas desde o século XV e, desde a Revolução Islâmica de 1979, o Irã é uma república teocrática xiita, cujo clero tem sua própria hierarquia e é organizado tendo os aiatolás como líderes maiores. Xiita, por sua vez, é aquele que cultiva a descendência direta do Profeta Maomé.

\subsection{A cisão}

A história dos dois principais grupos muçulmanos, xiitas e sunitas, é bastante confusa e intrincada, como toda história política do islamismo. Maomé, ao morrer (632 d.C.), não deixou sucessor direto (homem). Então, a cidade de Medina colocou em seu lugar Abu Bakr, que ganhou o título de califa (sucessor/vigário). Abu Bakr era sogro de Maomé e como tal conquistou de toda a Arábia, pelas armas. Bakr é responsável também pela não menos importante tarefa de ter realizado o primeiro levantamento de todos os escritos atribuídos a Maomé.

A confusão político-religiosa vem com a morte de Abu Bakr, que passou a chefia dos muçulmanos para um califa, Omar, que morreu assassinado. Um terceiro

sultão Kajar, com um golpe de estado. Coroa-se xá (rei, em persa/farsi), em 1926, com o nome de Reza Xá Pahlevi. Seu fillho governou o país até 1979, quando foi deposto pela Revolução Islâmica.

${ }^{13}$ A literatura e o jornalismo são pródigos em apresentar iranianos como árabes. Um dos mais grosseiros exemplos encontrados no Brasil, reunindo desinformação, preconceito e racismo, está no livro $A$ Revolução dos Turbantes, publicado em 1981. A contracapa traz em letras garrafais que se trata de um livro "Oportuno, Informativo, Isento". Falando sobre o casamento temporário, modalidade praticada desde os tempos de Maomé, o autor diz: "esse tipo de acasalamento temporário, apoiado pelo doutrinador senil do neo-islamismo, é abjeto, desprovido de sensibilidade (se é que árabe tem isso)...". In: Rui MEDEIROS, A Revolução dos Turbantes, Civilização Brasileira, pp. 58-59. 
califa, Uthman, assume a sucessão e após a morte deste, é seguido pela ascensão de Ali, primo de Maomé e casado com a filha preferida do profeta, Fatima (Fatémé, para os iranianos). Ali é assassinado pela tribo dos curaixitas.

O principal grupo surgido das cisões foi o dos sunitas (que seguem as sunas, coletânea das tradições do Corão). Já os xiitas eram os "partidários de Ali" (Shiat Ali) e para eles somente um único descendente de Maomé poderia vir a ser o chefe supremo. Desse modo, rejeitam os três primeiros califas, só aceitando o quarto califa, Ali, e seus continuadores, os 12 imãs ${ }^{14}$.

Os sunitas representam hoje a maior parte dos muçulmanos do mundo, enquanto os xiitas são minoria, ao lado de outras minorias como os alawitas, ahmadiitas, wahhabitas, carijitas, drusos e os ismaelitas. No Irã, cerca de $93 \%$ dos muçulmanos são xiitas.

\subsection{Karbala}

Todo dia é Ashura, todo lugar é Karbala. (Palavra de ordem da Revolução iraniana, criada por Ali Shari'ati ${ }^{15}$ )

\footnotetext{
${ }^{14}$ Os xiitas cultuam, além destes quatro primeiros califas, os seus continuadores a partir de Ali, que são os 12 imãs. Imã: lato sensu, é aquele que conduz as preces numa mesquita, stricto sensu (para os xiitas) são os 12 descendentes diretos de Ali que sucederam a Maomé.

${ }^{15}$ Ali Shari'ati (1933-1977), foi um importante ideólogo da Revolução Islâmica de 1979. Intelectual com formação em Paris, autor de 28 livros, é tido como uma das maiores influências de Khomeini no campo político. Uma das inspirações teóricas de Shariati é o intelectual francês Frantz Fanon (Martinica, 19251961). Fanon, engajado entre outras causas na independência algeriana, escreveu dezenas de obras onde trata da psicopatologia da colonização. Influenciou movimentos de libertação nacional e intelectuais que pensam as relações Oriente-Ocidente, como Edward Said.
} 
Para o que nos interessa aqui - uma herança ancestral cultural, com tendência à fabulação, recebida por Kiarostami -, importa saber que Ali teve dois filhos, Hassan e Hussein. O primeiro é morto por envenenamento. O segundo é assassinado em uma batalha em Karbala (hoje Iraque, próxima ao rio Eufrates), em 680, numa disputa pela liderança do islamismo com o califa Yazid.

Hussein foi morto a mando do califa sunita, a flechadas, e seu corpo cortado em pedaços, com partes sendo puxadas por cavalos. A cabeça de Hussein teria sido enviada de Karbala a Bagdá, e entregue a Yazid. A literatura xiita é rica em detalhes sobre o acontecimento, muitos deles de ordem sobrenatural, como a reação do cavalo de Hussein, que teria matado vários partidários do califa que estavam em volta. A memória de todo o episódio, chamada de Ashura, persiste através da cerimônia da batalha de Karbala, chamada de Tazieh, onde o martírio de Hussein é encenado todos os anos no $10^{\circ}$ dia do Muharram (primeiro mês do calendário islâmico) e representa o autosacrifício supremo a que foi submetido o filho de Ali. Sua tortura é dramatizada pelos praticantes mais entusiasmados com um realismo tal que eles até sangram ao baterem-se nas costas com correntes e chicotes com pregos, num espetáculo de flagelação envolvendo homens e meninos nas ruas das cidades xiitas do Irã e do Iraque ${ }^{16}$.

Segundo Charles Virolleaud, em Le Théâtre Persan ou Le Drama de Kerbéla, da lenda se fez o mito. De fato, a batalha teria sido mal conduzida por Hussein, mas se transformou pouco a pouco, na imaginação dos xiitas, em um acontecimento de

\footnotetext{
${ }^{16}$ A revista National Geographic de junho de 2004 traz na reportagem especial, Reaching for Power, vasto registro fotográfico das encenações no Irã e no Iraque. Farta ilustração pode ser encontrada também em Peter CHELKOWSKI e Hamid DABASHI in: Staging a Revolution: the art of persuasion in the Islamic Republic of Iran.
} 
incalculável importância. Para os xiitas, se Hussein tombou em Karbala não foi por sua culpa, ou qualquer imprudência sua.

\begin{abstract}
Hosséïn foi, na verdade, sacrificado pela salvação de seu povo, pela sua salvação(...). Se ele foi degolado 'como uma ovelha', foi por obediência a Deus, que decidiu, desde o dia da criação, que seria assim. Para os xiitas, Hosséïn não foi somente um combatente valoroso, mas um mártir...Um tal personagem deveria naturalmente não pertencer à história, onde ele não teve se não que um papel modesto. ${ }^{17}$
\end{abstract}

A analogia com o martírio de Cristo é evidente, mas o que chama a atenção é que o autor traz à tona um episódio crucial para a história do islamismo xiita que, no entanto, tem contornos de exagero, de mistificação por parte de quem passou a relatar estes fatos. Comprovando sua tese, Virolleaud cita um arabista holandês de origem francesa, René Dozy, que afirmou serem os escritores xiitas os maiores falsificadores da história.

Virolleaud também se refere à pesquisa do conde de Gobineau, que revelou à Europa a existência em persa de uma vasta literatura dramática, que nada mais era que o teatro de Karbala. A encenação do martírio de Hussein teria causado forte impressão em Gobineau, que o comparou às tragédias gregas. ${ }^{18}$

\footnotetext{
${ }^{17}$ In: Charles VIROLLEAUD, Le Théâtre Persan ou Le Drama de Kerbéla, p. 4. O nome de Hossein é encontrado de diversas formas, dependendo do país e do autor. Na citação, mantivemos a grafia "Hosséïn" utilizada por Virolleaud, mas neste trabalho preferimos a grafia mais usada em português.

${ }^{18}$ Virolleaud não chega a informar, mas Joseph-Arthur Gobineau, o conde de Gobineau, (1816-1882), como diplomata francês serviu em Teerã (além de vários outras cidades, como Rio de Janeiro). Foi secretário do escritor e estadista francês Alexis de Tocqueville e sua teoria do determinismo racial teve uma grande influência no desenvolvimento de políticas racistas na Europa. Cf. Rubem Q. COBRA, in: Gobineau.. Site "Filosofia Contemporânea", disponível em: http://www.cobra.pages.nom.br/fcgobineau.html
} 
Outras fontes, como Peter Chelkowski e Hamid Dabashi, em Staging a Revolution: the art of persuasion in the Islamic Republic of Iran, reforçam que a batalha foi o ápice de uma disputa política pela sucessão de Maomé como líder religioso e político de uma região. As descrições da batalha foram ganhando mais dramaticidade com o tempo, segundo eles.

Não se trata aqui de afirmar que a construção da identidade xiita foi baseada numa mentira. Apenas de chamar a atenção para a vocação persa para encenar, dramatizar fatos ocorridos, como forma de reverenciar seus heróis e perpetuar sua história. Portanto, a escolha de Kiarostami ao dar o formato do docudrama à história de Sabzian, em Close-up, insere-se em uma longa tradição e não está livre da perspectiva do exagero, de uma interpretação deformada dos fatos.

O próprio Kiarostami chegou a montar, em Roma, um espetáculo interativo misturando teatro e cinema, onde a cerimônia do martírio de Hussein, através da Tazieh, foi a inspiração. Em entrevista ao jornal francês L'Humanité, Kiarostami disse que tinha o desejo de montar a Tazieh desde muito tempo. Lembrou que na representação melodramática de uma das partes (são dez partes, ou textos, ao todo), onde os atores cantam e choram, a modernidade consiste em que os espectadores interagem, cantando e chorando também. Kiarostami teve a idéia de atravessar o Irã registrando com uma câmera digital esta reação do público. Em cinco telas, Kiarostami mostrou o resultado numa espécie de instalação, a convite do diretor do Teatro di Roma. "Tazieh é efetivamente a chave da procura por uma modernidade dentro da minha obra, 
que passa antes de tudo pela emoção, que permanece como uma das minhas experiências mais fortes." ${ }^{\prime 19}$, afirmou Kiarostami.

Portanto, o teatro de Karbala, parece ser uma chave religiosa importante para compreender Kiarostami.

${ }^{19}$ Entrevista a Michèle LEVIEUX , disponível em: http://www.humanite.fr/journal/2004-05-19/2004-0519-393994 


\section{2 - O realismo poético}

A relação entre cinema e literatura e o surgimento do movimento motafävet, $o$ cinema diferente, a partir do filme The Cow.

$\mathrm{Na}$ Arábia pré-islâmica, o poder da palavra inspirava temor, respeito e admiração. Natural, pois as sociedades tribais da época eram compostas em sua maioria por analfabetos. O papel da palavra não diminui com o advento do islã, sendo que, depois de Maomé, entre as profissões mais importantes destacava-se a de poeta. Os poetas representavam uma espécie de intermediário entre o além e a terra.

Poesia foi e é tão popular no Irã, que mesmo crianças dedicam-se a recitar poemas de Hafez, Saadi e Omar Kayaam, que ao lado de Ferdowsi formam os grandes nomes da literatura persa e cunharam um estilo tão marcante que é comum a citação deles nos filmes. O próprio Makhmalbaf, falando de Gabbeh, atribui a Omar Khayaam o poder das imagens. ${ }^{20}$

Hormuz Kéy, ilustrando esta relação de apropriação entre cinema e literatura, inicia sua tese de doutorado com esta espécie de elegia ao cinema, antes de sua criação, escrita por Omar Kayaam: "Esta roda do céu, nós a giramos sem parar.../ Pense na lanterna mágica/ Suponha que o sol seja a lâmpada e o universo uma lanterna/ Então nós, nós somos imagens estupefatas." 21

\footnotetext{
${ }^{20}$ Ivonete PINTO, Descobrindo o Irã.

${ }^{21}$ In:Hormuz KÉY, Le Cinéma Iranien: L'Image d'une Societé en Bouillonnement. p. 6. No original: "Cette roue du ciel, nous y tournons sans cesse.../Pense à la lanterne magique/Suppose que le soleil est la lampe et l'univers une lanterne/Alors nous, nous en sommes des images ébahies. (Omar Kayaam, 10501123)
} 
O cinema iraniano, por sua vez, tem registrado esta afinidade com a poesia em várias épocas. Diferente do propagado, Samira Makhmalbaf não é a mulher cineasta mais cultuada no Irã. Este status pertence à poeta Forough Farrokhzad, que dirigiu o clássico documentário The House is Black (Khaneh siah ast, 1963). Foi seu único filme, tendo morrido em um acidente de carro cinco anos depois, aos 32 anos, quando dirigia um documentário para a rede BBC. Celebrada como poeta, inaugurou com este documentário sobre uma colônia de leprosos no interior do Irã, a não-ficção poética. Enquanto mostra imagens chocantes, mas com evidente senso ético, recita poemas de sua autoria, de um humanismo pungente. Tem legiões de admiradores no Irã, entre os quais Kiarostami. Ele tirou de um poema de Forough o título de $E$ O Ventro nos Levará (Bad Maara Jahad Bord, 1999). É dela também um poema recitado no filme por um personagem, que fala do vento, da lua e do ardor do desejo, tema este que por sua vez dialoga com os temas de Omar Kayaam. Kiarostami expressa assim sua admiração por Forough Farrokhzad: “É a mais audaciosa das poetas iranianas e a primeira a ter ousado falar, no Irã, de seu corpo, de sua feminilidade. (...)Farrokhzad exerceu influência sobre todos os poetas que a sucederam". ${ }^{22}$

Se nos voltarmos para a poesia pela qual os persas são mais conhecidos, não podemos deixar de citar Iran is my Land, de Parviz Kimiavi (Iran saray-e man ast, 1999) ${ }^{23}$. Depois de 20 anos sem filmar, Kimiavi voltou à cena trazendo consigo os maiores poetas persas. Seu personagem principal é um jovem escritor que compilou todos os poemas clássicos e tenta permissão das autoridades para publicá-lo. Numa viagem pelo deserto, “encontra” Ferdowsi, Omar Khayyam, Saadi e Hafez.

\footnotetext{
${ }^{22}$ In: Abbas Kiarostami - Les yeux du coeur, entrevista a Stéphane GOUDET, Positif, 466, dez. 1999, p. 10 .
} 
Ferdowsi (930-1020) será motivo de um dos primeiros atos censores no Irã. O filme Ferdowsi (Abdol Hossein Sepanta, 1935) tentou mostrar a morte do poeta como realmente foi. Por ter dedicado os últimos anos a escrever uma epopéia de encomenda para o rei e por este não lhe ter pago nada, acabou na miséria, tendo somente a filha no cortejo fúnebre. Salienta o pesquisador Mamad Haghighat que Reza Xá obrigou Sepanta a modificar a cena final por entender que seu prestígio como rei ficaria abalado. Assim, no filme, Ferdowsi recebeu do rei o dinheiro prometido e morreu rico. ${ }^{24}$

Voltando para os anos 60, mais exatamente 1969, chegamos a um momento de ruptura entre o cinema de puro entretenimento, para um cinema de reflexão social. Este ano marcará uma quebra de estilo no cinema iraniano, que vai influenciar diretores então em início de carreira, como Kiarostami. É The Cow (Gav, de Dariush Mehrjui, 1969), um sucesso de crítica que entrou para a história daquele cinema. Nota-se, mais uma vez, a literatura como fonte. O filme é uma adaptação de um conto do escritor e dramaturgo Gholam-Hossein Sa'edi e registra o apego de um homem pobre a uma vaca. Com a morte do animal, o homem vai definhando e, aos olhos da população, enlouquecendo. O crédito ao neo-realismo italiano passa, nesse momento, a ser recorrente nas análises, especialmente produzidas na Europa.

Porém, uma nova investigação poderá revelar que naquele momento surgiam os traços incipientes do que hoje é considerado um dos elementos mais marcantes e identificadores da estética do cinema iraniano, que é o aspecto de documentário, ou falso documentário. A dialógica entre verdade e mentira, fato e invenção, que permeia

\footnotetext{
${ }^{23}$ Visto no Farj Film International Festival, de Teerã, em 2001.

${ }^{24}$ In: Mamad HAGHIGHAT, Histoire du Cinéma Iranien - 1900-1999, p. 31.
} 
muitas das produções iranianas. Os rudimentos desta dialógica já estavam em The Cow, filme que dá início ao movimento motafävet, o "cinema diferente".

O filme de Mehrjui introduz o realismo no cinema iraniano ao mostrar o mundo rural sem escamotear a pobreza. Produzido com recursos do Ministério da Cultura do Xá, o diretor foi obrigado a colocar uma legenda inicial explicativa: "Os acontecimentos deste filme datam de 40 anos atrás e não têm nenhuma relação com a época atual"25.

De fato, a legenda não correspondia à realidade, e afora isto, como defende Eric Egan, o filme se insere num processo de autocompreensão das nuances da sociedade iraniana, política e culturalmente, quando o país passou a produzir obras comerciais com regularidade (os chamados film farsi), documentários e filmes premiados, como The Cow. ${ }^{26}$ O título conquistou o prêmio da crítica em Veneza (1971), no mesmo ano em que concorriam os italianos Antonioni, Fellini, De Sica e Visconti, Satyajit Ray, da Índia, e Akira Kurosawa, do Japão. ${ }^{27}$

Hormuz Kéy examina The Cow sob o ponto de vista sufi, elemento que é interessante guardar para as convergências que faremos com relação a Close-up mais adiante. Para Kéy, toda filosofia e poética de The Cow tem fonte no esoterismo iraniano, mais particularmente no misticismo sufi. Ele cita o místico sufi Hallaj (858922), que "entrando em rebelião contra uma certa divindade (...), proclama seu próprio Deus, que ele chamou "Haq" (termo que significa ao mesmo tempo "verdade" e "Deus"), não hesitando em clamar "Anal Haq! ("Eu sou o verdadeiro").,"28 Note-se que

\footnotetext{
${ }^{25}$ Idem, p. 67.

${ }^{26}$ Eric EGAN, The Films of Makhmalbaf-Cinema, Politics \& Culture in Iran.

27 Idem.

${ }^{28}$ Hormuz KÉY, op. cit., p. 24
} 
o termo "Haq" foi traduzido por Kéy como "verdadeiro". Segundo Jamil Ibrahim Iskandar, "Haq" significa, literalmente, "verdade", enquanto para "verdadeiro" a palavra correta seria Haquiqui. Jamil Ibrahim Iskandar diz que é comum encontrar este erro em vários autores ${ }^{29}$.

Voltando a Hormuz Kéy. Kéy diz, então, que o autor Sa'edi e o diretor Merhjui, de The Cow, trabalharam com os arquétipos do misticismo iraniano e propuseram um comportamento semelhante para o dono da vaca. Após a morte do animal, o personagem afirma: "Eu não sou Mashd Hassan, eu sou a vaca de Mash Hassan". ${ }^{30}$ O personagem de Close-up, como veremos, também transforma-se em outro.

\subsection{Realismo e Naturalismo}

O conceito de naturalismo aqui segue a definição de Ismail Xavier. Ele aborda o naturalismo como sendo "imitação da vida", através de elementos como a decupagem clássica e a atuação dos atores fiel ao comportamento humano. Já o realismo, segundo Xavier, estaria relacionado à captação do "sentido dos fatos". Nesta análise, portanto, trabalhamos o realismo em Kiarostami, o que não significa eliminar o naturalismo de sua obra, como no capítulo 5, em que o conceito é utilizado por Gilberto Perez ao referir-se à modernidade de Kiarostami. O realismo em Kiarostami também não exclui o naturalismo no que diz respeito à performance dos atores não profissionais com os quais

\footnotetext{
${ }^{29}$ Informação oral à autora. Jamil Ibrahim Iskandar é doutor em filosofia, professor da PUC/Paraná, especializado em filósofos muçulmanos, como Ibn Sina (Avicena).

${ }^{30}$ Hormuz KÉY, op. cit., p. 24.
} 
o diretor trabalha. E, no caso de Close-up principalmente, pois os personagens são os próprios protagonistas dos fatos.

O realismo no cinema é colocado como um dilema para Jane Gaines em Collecting Visible Evidence. Ela afirma que os estudos de cinema refletem esta questão pelo menos desde a década de 50 , quando o realismo na tela tornou-se um problema filosófico, principalmente em função do neo-realismo italiano. Segundo Gaines, mais especificamente o realismo no documentário, historicamente tem sido uma questão de apresentar similaridade: uma imagem de determinada coisa parece com a imagem da coisa em si. Este tipo de discussão, naturalmente, acaba interessando áreas como a epistemologia, a semiótica e também a antropologia. É na antropologia que, conforme Gaines, o dilema do realismo é mais radical, apresentando os temas da iconicidade e da indexicabilidade, fazendo-se a clássica pergunta: quem representa e quem é representado? O realismo praticamente tornou-se sinônimo de (resemblence) imitação (da realidade) a partir de Nanook de Norte, fascinando o público com a sua capacidade de similaridade, como um caminho para o conhecimento. Michael Renov, coorganizador do Collecting Visible Evidence, lembra que na Visible Evidence, a conferência promovida pela Society for Cinema Studies, em 1998, os trabalhos apontaram para a crescente dificuldade de separar ficção da não-ficção. No entanto, também ficou claro o crescente interesse pelo documentário e sua capacidade de ressonância nas discussões em torno dos reality shows, do sentido do que é público e do que é privado. 


\section{3 - Imagem interdita}

Como o Irã insere-se na "civilização da imagem"; a diferença entre imagem proibida e proibição à idolatria.

Feitas as primeiras aproximações e estabelecidos alguns conceitos e influências, passemos para o item que se configura como fundamental quando o teor da reflexão envolve imagem e islã.

Enquanto os iranianos encontram-se entre os povos mais demonizados em função da posição radical de seus governantes, o cinema iraniano tem sido reconhecido como um dos mais humanistas em conteúdo e mais criativos na forma. Esta cinematografia periférica tem sido distinguida internacionalmente, em especial através de festivais de cinema como de Veneza e Cannes. Uma projeção que teve seu auge nos anos 90 e que possibilitou que o "cinema iraniano", por suas características, ganhasse o cunho de gênero e fosse empregado como tal em análises fílmicas nos mais diferentes países.

Com uma população de cerca de 70 milhões de habitantes, o País ostenta uma invejável produção cinematográfica, que atinge, na média dos últimos anos, entre 70 e 80 filmes. O alcance internacional desta produção, comparada com a do Brasil, arranca comentários como o de Jean-Claude Carrière:

Mas é inacreditável para mim saber que um país tão grandioso quanto o Brasil não é capaz de desenvolver um mercado de cinema forte. Até o Irã conseguiu. Aquele país tão pequeno se 
comparado ao de vocês tem uma produção que alcança não apenas festivais internacionais, como os circuitos de exibição do mundo inteiro. Como é que vocês não conseguem? ${ }^{31}$

O Irã é, portanto, produtor de conteúdo simbólico. Conteúdo este insignificante no cálculo do Produto Interno Bruto do país, que não rivaliza com o petróleo (trata-se do quarto maior produtor de petróleo do mundo), mas que é tão poderoso quanto armas atômicas. Paralelo à disputa pela energia atômica, o mundo disputa o poder da representação, pelo imaginário. Ou seja, o cinema é produto estratégico e o aiatolá Khomeini, líder da Revolução Islâmica de 1979, sabia disso ao incentivar a indústria local do cinema $^{32}$, mesmo que fosse uma contradição, pois a imagem seria harám (ilícita).

Vivemos na civilização da imagem. Para Boris Kossoy, esta civilização surgiu no momento em que a litografia, ao reproduzir em série as pinturas dos artistas do Oitocentos, inaugura o "fenômeno do consumo da imagem enquanto produto estético de interesse artístico e documental. (...) O conhecimento visual do mundo através de imagens se torna moda, particularmente após as primeiras décadas do advento da fotografia." ${ }^{33}$ Diríamos que, daí até o advento do fenômeno dos reality shows na televisão, foi um passo. A humanidade está irremediavelmente viciada na sua própria imagem.

\footnotetext{
31 "O inconformista", entrevista com Jean-Claude Carrière, publicada no jornal O Globo 11/04/2006 Segundo Caderno. In: http://blackandwhiteincolor.blogspot.com/2006/04/jean-claude-carrire-oinconformista.html.

${ }^{32}$ A instituição de maior fomento ao cinema no Irã é a Fundação Farabi de Cinema. Criada em 1983 pelo ex-presidente Mohammed Khatami, na época Ministro da Cultura (1982-93). Khatami é considerado o grande impulsionador do cinema iraniano e teve apoio do líder Khomeini em suas iniciativas. Mais detalhes in: Ivonete PINTO, Descobrindo o Irã, op. cit.

${ }^{33}$ In: Boris KOSSOY, Fotografia \& História, p. 134.
} 
No âmbito das religiões, podemos notar que, mesmo no cristianismo e no judaísmo, a questão da imagem é complexa.

No Antigo Testamento, Êxodo 20:4, Deus proibe a produção de imagens: "Não farás para ti imagem esculpida de nada que se assemelhe ao que existe lá em cima nos céus, ou embaixo na terra, ou nas águas que estão debaixo da terra". O contexto desta proibição vem do fato de que os judeus, vivendo entre os egípcios após o êxodo, estavam influenciados pelo comportamento idólatra. Para os cristãos, a proibição da imagem existiu até o Segundo Concílio de Nicéia (787d.C.), quando foi declarada a legitimidade da veneração de imagens desde a cruz, às imagens da Virgem Maria, dos anjos e dos santos, tanto nas igrejas como nas casas. No Novo Testamento não há proibição à produção de imagem, mas à idolatria, ou seja, à imagem que representa uma divindade e que é adorada como se fosse a própria divindade.

Em pesquisa realizada para o artigo De Hafez a Makhmalbaf - A influência da literatura no cinema iraniano ${ }^{34}$, trabalhamos com a idéia de que enquanto nos países cristãos somos inundados por figuras de Jesus Cristo pregado na cruz, por milhares de santos e até por representações de Deus com longas barbas brancas e corpo robusto (a clássica $A$ Criação de Adão, de Michelangelo), no Oriente islâmico o que impera são as palavras. Não há imagens no Corão, nem representações humanas nas mesquitas. E, salvo manifestações não-islâmicas, a figura de Alá nunca é representada.

No Corão, não há a proibição explícita à reprodução da imagem. Conforme Alain Besançon, em A imagem Proibida, há apenas um hadith (ditos e feitos de Maomé)

\footnotetext{
${ }^{34}$ Mariarosaria FABRIS (Org). "De Hafez a Makhmalbaf - A influência da literatura no cinema iraniano", Ivonete PINTO. Socine - III Estudos de Cinema.
} 
que põe na boca do Profeta Maomé estas palavras: "Os anjos não entrarão numa morada onde exista qualquer tipo de imagem."35 Mas Besançon lembra que há várias passagens no Corão quanto à objeção à idolatria, onde a imagem tornou-se inconcebível por causa da noção metafísica de Deus.

Basta o ato de submissão (islam) a esse deus para fazer com que a associação (shirk) dele a qualquer conceito exterior à sua essência, a qualquer pessoa (como entre os cristãos) e, com mais forte razão, a qualquer matéria, seja vista com horror como uma agressão à unidade, como um retorno ao politeísmo. ${ }^{36}$

Besançon afirma ainda que é a própria idéia de Deus que afasta uma representação dele, idéia contida na sura (ou surata, o mesmo que capítulo) CVII: "Ele, Deus, é Uno! (...)/ Ele não engendra/ Ele não é engendrado/ninguém é igual a Ele!”37

Para o muçulmano, é simplesmente impossível representar Deus. Se ele não tem forma, então não pode ter imagem. Imagem, somente da palavra escrita, por isto certamente a arte da caligrafia se desenvolveu tanto no mundo muçulmano.

Na história islâmica, esta discussão nasce quando Meca foi conquistada pelos muçulmanos: Maomé comandou a destruição de todos os ídolos que os árabes pagãos

\footnotetext{
${ }^{35}$ In: Alain BESANÇON, A imagem proibida - uma história intelectual da iconoclastia, p. 131. Este hadith aparece de forma completa no capítulo 14 , quando falamos na interdição de cães.

${ }^{36}$ Idem, p. 130.

${ }^{37}$ Idem. Chamamos a atenção para o fato de que há outras traduções desta sura e de resto de todo Corão. Ela aparece como sendo a sura 112, com este texto: "Ele é Allah, Único (...)/Não gerou e não foi gerado./E não há ninguém igual a Ele." In: Tradução do Sentido Nobre do Corão para a Língua Portuguesa, p. 1059. Cabe notar também que esta recente tradução do Corão, publicada com o patrocínio do Rei Fahd, da Arábia Saudita, é assinada pelo Dr. Helmi Nasr, professor de Estudos Árabes e Islâmicos da USP. A publicação não leva o nome de "Corão", mas "Tradução do Sentido Nobre do Corão", visto que a ortodoxia islâmica só considera como Corão o original em árabe, pois teria sido nesta língua que o texto sagrado foi ditado pelo anjo Gabriel ao Profeta Maomé. A idéia é que a expressão divina é imutável.
} 
haviam erigido na praça da $\mathrm{Caaba}^{38}$ e só então o profeta entrou no santuário. Nas paredes do santuário havia muitas pinturas e Maomé teria ordenado que todas fossem retiradas, exceto a que representava Maria e Jesus.

Jean Baudrillard foi um dos inúmeros autores ocidentais a tratar da proibição da imagem no islã, contribuindo, porém, com uma idéia original: para ele, a questão está ligada ao simulacro da divindade. Ao destruir os ícones (simulacros) que representavam o divino, os iconoclastas liderados por Maomé tinham receio que o aparato visível dos ícones substituísse a idéia de Deus.

É precisamente porque estes [ícones] apresentavam esta onipotência dos simulacros, esta faculdade que têm de apagar Deus da consciência dos homens e esta verdade que deixam entrever, destruidora, aniquiladora, de que no fundo Deus nunda existiu, que nunca existiu nada senão o simulacro e mesmo que o próprio Deus nunca foi senão o seu próprio simulacro - daí vinha a sua raiva em destruir as imagens.

Para Titus Burckhardt, em A Arte Sagrada no Oriente e no Ocidente, no contexto da imagem na arte muçulmana a discussão concentra-se na questão da Unidade, que em si mesma é eminentemente concreta, contudo apresenta-se ao espírito humano como uma idéia abstrata. Este fato, somado a determinados fatores da mentalidade semítica, explicaria o caráter abstrato da arte muçulmana. "O Islã é centrado na Unidade, e a Unidade não pode ser expressa por imagem alguma." ${ }^{40}$

\footnotetext{
${ }^{38}$ Caaba: Mesquita sagrada de Al Masjid Al-Haram, em Meca, na Arábia Saudita, é considerado pelos muçulmanos como o lugar mais sagrado do mundo. Em seu interior encontra-se a pedra negra, uma das relíquias mais sagradas do islã.

${ }^{39}$ Jean BAUDRILLARD, Simulacros e Simulação, p. 13.

${ }^{40}$ In: Titus BURCKHARDT, A Arte Sagrada no Oriente e no Ocidente - Princípios e Métodos, p. 161.
} 
A proibição das imagens no islã não seria, entretanto, absoluta. A arte islâmica, inclusive, desenvolveu-se através, principalmente, da caligrafia, e miniaturas mostrando animais e plantas eram muito comuns. Uma imagem plana seria tolerada na arte profana, desde que não representasse Deus, nem Maomé. Até aí parece que todos estão de acordo. A controvérsia surge quando grupos de diversas escolas do pensamento islâmico interpretam versículos do Corão a sua maneira.

\subsection{Poder da imagem}

Xiitas e sunitas, sabemos, aceitam diferentes coleções de hadith (ou, para sermos mais precisos, ahádith, no plural) como genuínas, resultando daí posicionamentos diferentes. $^{41}$

Em L'Image et l'Islam, Mohamed Aziza lembra: "No paraíso, existe uma loja onde vende-se imagens" ${ }^{, 42}$, por paradoxal que seja, este é um hadith do profeta, mas que bem demonstra que o Isla admite uma diversidade tal de conceitos, máximas e proibições que encontram, dentro do próprio islam, suas contradições.

A primeira vista, o dispositivo do vídeo foi absorvido pela sociedade islâmica. Bin Laden mandou suas mensagens após o 11 de setembro por vídeo. Há um mercado de vídeos na Palestina, trazendo depoimentos finais dos homens-bomba suicidas. Juba,

\footnotetext{
${ }^{41}$ Os quatro principais compiladores de hadiths são Sahih Bukhari, Sahih Muslim, Sunan Abu-Dawud e Malik's Muwatta. A University of Southern Califórnia é uma das instituições cujos departamentos dedicados ao estudo do islã disponibiliza na Internet estas compilações, assim como o site Al Islam, referido na bibliografia.

${ }^{42}$ In: Mohamed AZIZA. L'Image et l'Islam, p. 7.
} 
um franco atirador sunita do Iraque, mata soldados americanos com tiros certeiros e divulga suas façanhas em fitas de vídeo disputadas no mercado iraquiano.

Já no Irã, em lares que seguem estritamente a religião, não há fotos da família em porta-retratos, ou nas paredes. Se pegarmos um exemplo de uma família sunita, que também segue os preceitos quanto à imagem, veremos que eles não colocam as fotos na sala, mas se formos ao quarto do casal, por exemplo, podemos encontrar fotos da família e a argumentação de que se trata do espaço menos público da casa. Não há norma no Corão que estabeleça esta distinção, mas por tradição (com base em hadith) tal comportamento é seguido. Poderíamos dizer, sem dissociar o conceito de hadith como uma tradição, que se trata de uma "tradição inventada". No texto introdutório para o livro A Invenção das Tradições, o historiador Eric Hobsbawn desenvolve este conceito:

\begin{abstract}
Por "tradição inventada" entende-se um conjunto de práticas, normalmente reguladas por regras tácita ou abertamente aceitas; tais práticas, de natureza ritual ou simbólica, visam inculcar certos valores e normas de comportamento através da repetição, o que implica, automaticamente, uma continuidade em relação ao passado. ${ }^{43}$
\end{abstract}

Assim, na sociedade islâmica a representação de figuras humanas é vista sob suspeição por conta da tradição, com referência ou não na norma religiosa, mas o fato é que o iraniano que tem acesso ao cinema e à televisão, mesmo com conteúdo censurado pelo Estado teocrático, está sujeito ao poder das imagens. E está tão contaminado pelas imagens quanto um ocidental de um país laico qualquer. Em seu La Mentira Social, Ignácio Gómez de Liaño diz que a informação visual assaltou o

\footnotetext{
${ }^{43}$ In: Eric HOBSBAWN \& Terence RANGER (org), A Invenção das Tradições, p. 9.
} 
coração das massas e minorias e irrompeu nos seus centros cognitivos e práticos por uma via direta.

Um dos efeitos mais sérios do cinema, da televisão - e da informação visual em geral - consistiu em alterar radicalmente as relações do homem com seu meio, perturbando o sistema de condicionamentos recíprocos de ambos, isto é, do indivíduo e seu entorno vital. ${ }^{44}$

Mesmo que surgido séculos adiante do Corão, o cinema sempre teve esse “defeito de origem", de não poder se dissociar da imagem, e sem dúvida é transgressor no universo islâmico ortodoxo. Mulás (religiosos, equivalente aos clérigos católicos) fanáticos, por exemplo, logo no início do cinema no Irã, nos idos do século passado, argumentavam com preceitos da teologia islâmica, que considera inaceitável, além da idolatria, que se simule qualquer ato relativo ao que o próprio Deus criou. A imagem fílmica, então, essência da essência da simulação, seria blasfêmia.

Um episódio que marca os preâmbulos da Revolução Islâmica foi entendido por muitos autores ocidentais como demonstração de intolerância à imagem. $\mathrm{O}$ episódio aconteceu em agosto de 1978 num cinema da cidade de Abadan, que abrigava uma das maiores refinarias de petróleo do país. Durante a sessão de um filme iraniano, as portas foram trancadas por fora e o cinema foi incendiado. Algumas fontes dão como 400, outras como 700 mortos. Uma das versões na época dizia que a ordem do ataque teria partido de religiosos ortodoxos. Outras acusaram a polícia secreta Savak (Sazeman-e Ettelaat va Amniyat-e Keshvar), que teria agido por ordem direta de Reza Pahlevi. Mas passados mais de 20 anos se desconhece a responsabilidade pelo assassinato de

\footnotetext{
${ }^{44}$ In: Ignácio Gómez de LIAÑO, La Mentira Social-Imagens, Mitos y Conducta, p. 193
} 
inocentes espectadores, que assistiam a um inocente filme chamado $O$ Veado, num cinema com o singelo nome de Rex.

Também é prudente considerar que se a interdição procede quanto à imagem divina, a proibição da imagem do homem seria uma mistificação do mundo islâmico. De fato, Alá e o profeta Maomé não podem e não são representados, mas imagens “islamicamente corretas" são aceitas. E este é o ponto: o cinema deve ser encarado no contexto iraniano não tanto pela premissa da imagem, mas pelo que pode representar de perigo para a disseminação de valores contrários ao islã. O aiatolá Khomeini, por sinal, ignorou esta discussão filosófica sobre interdito da imagem. Aparecia na TV diariamente e um dos recursos de destaque no Complexo Iman Khomeini, em Teerã, é o Museu da Imagem, que conta a história da Revolução, principalmente através da imagem de filmes, vídeos e fotos.

É preciso admitir, no entanto, que embora a produção cinematográfica no Irã alcance números significativos (média de 70 filmes por ano), a produção televisiva é pequena e limita-se a poucos canais.

Naturalmente, a difusão das antenas parabólicas é um apelo que os governos de países muçulmanos tentam interceptar, pois com elas vem a difusão de conteúdo simbólico do Ocidente, impregnado de valores anti-islâmicos. São as antenas "paradiaboliques" empregado em países islâmicos que controlam a entrada de programação estrangeira e pró́bem a instalação das antenas nas residências. Clément observa que ao mesmo tempo

\footnotetext{
45 No original, em francês. "L'Image dans de monde arabe: Interdit et possibilites". In: Jean-François CLÉMENT e Gilbert BEAUGÉ, G. L'Image Dans le Monde Arabe. Paris: CNRS Éditions, 1995, p. 11.
} 
as parabólicas são associadas ao demônio, a partícula "para" tem o duplo sentido de significar “oposição". Seriam, então, antenas contra o diabo. Na extensão deste insight, o autor quer trazer ao debate a própria contradição do interdito à imagem no mundo muçulmano: “(...) se o islã condena realmente a imagem, não haveria mais um só muçulmano sobre a terra há muito tempo pois o desenvolvimento das imagens seria o critério mais rigoroso de desislamização, critério que permanece quantificável."46

Com esta contradição, queremos sublinhar que a questão da imagem no islã deve ser relativizada quanto a um possível caráter de interdito. O que o islã condena é a representação de Deus, em função de sua essência metafísica, e a idolatria. No entanto, se considerarmos que o termo idolatria é composto por eidolon (imagem) + latreia (culto), veremos que o cinema não escapa a esta conotação. Mais do que isto, representa um elemento a somar na enorme complexidade que é o universo religioso islâmico xiita.

E vale lembrar que quando Khomeini ainda estava vivo foi criada a Fundação Farabi de Cinema, sendo que o motivo fundamental para o forte incentivo à produção nacional foi a política do governo de combate à entrada dos filmes americanos no Irã e a toda produção de conteúdo islamicamente incorreto. E, ainda, há uma questão fortemente cultural aí: mesmo convivendo com este problema dialético quanto à imagem, o cinema se desenvolveu no Irã tanto quanto em países como Egito e Índia. Nestes países, a adesão à hegemonia dos Estados Unidos e Europa não aconteceu, pois certos códigos de comportamento simplesmente não eram compreendidos. Então, para

\footnotetext{
${ }^{46} I d e m$, p. 11.
} 
consumo local, era preciso produzir obras locais ${ }^{47}$. É neste cenário profícuo que nasceu Kiarostami.

${ }^{47}$ Para mais informações ver artigo "Um Close em Bollywood", Ivonete PINTO. In: Revista Arquipélago, $n^{\circ} 4$, pp. 7-10. 


\section{4- A manipulação do artifício}

A importância de Kiarostami no cenário mundial do cinema, a inquietude, a natureza experimental, sua relação com a fotografia, sua predileção pelo trompe l'oeil.

\subsection{Cinema autoral}

Para localizar Kiarostami na cinematografia iraniana, é preciso citar o instituto chamado Kanun - Centro para o Desenvolvimento Intelectual de Crianças e Adolescentes (Kanun-e Parvaresh-e Fekri Kukadan va Nuyavanan), criado nos anos 60 em Teerã. Kiarostami entrou neste centro a convite de um amigo, sem ter tido formação como realizador. O diretor, que cursou Artes Plásticas, havia trabalhado anteriormente como publicitário, fazendo comerciais para televisão, e até no departamento de trânsito de Teerã passou um tempo. Foi entrando no centro, sem motivação maior, que Kiarostami dirigiu seu primeiro curta, O Pão e o Beco (Nan va Kuche, Irã, 1970), inaugurando a seção cinematográfica do $\mathrm{Kanun}^{48}$. Esta entidade, criada pela esposa do xá Reza Pahlevi em 1965, foi determinante para o desenvolvimento do cinema no país, em especial por dar oportunidade a jovens diretores, o que acabou por gerar o movimento chamado por alguns autores como "novo cinema iraniano".

Com o decorrer no tempo - e são quase 40 anos de cinema -, Kiarostami foi trilhando caminho próprio. Embora muitas vezes trabalhando com os mesmos

\footnotetext{
${ }^{48}$ Este filme também inaugura um traço dos personagens kiarostâmicos, o da determinação em atingir um objetivo, neste caso, um menino que precisa passar por um cão ameaçador.
} 
elementos de outros diretores (metáforas, crianças, locações, etc.), foi ficando cada vez mais difícil enquadrar Kiarostami em um movimento, ou associá-lo a um gênero. No entanto, seu papel para o cinema iraniano é indiscutível e transcende fronteiras. Embora outros cineastas, como Majid Majid e Mohsen Makhmalbaf sejam mais populares no Irã, alcançando maior público, foi Kiarostami o cineasta a projetar esta cinematografia no exterior, notadamente com Gosto de Cereja (Taam-e Guilas, Leão de Ouro em Cannes, 1997). É Kiarostami quem suscita mais análises, tanto em abordagens jornalísticas, quanto em estudos acadêmicos. São dezenas de livros publicados sobre ele em culturas tão distintas como Japão, Nova Zelândia, Itália e Estados Unidos.

Suas inquietações estéticas e filosóficas repercutem entre cineastas do mundo inteiro, em especial na França, país onde os cinemas periféricos encontram mais espaço de exibição e reflexão ${ }^{49}$. Godard é um exemplo, na França, do apreço a Kiarostami ("Ele sempre tem bons filmes, ainda que poucos" ${ }^{50}$ ). Um apreço, diga-se, questionado por cineastas como o argentino Fernando Solanas, que considera um exagero o tratamento que Kiarostami recebe. ${ }^{51}$ Já cineastas como Akira Kurosawa e teóricos como David Bordwell, expressaram sua admiração por Kiarostami, identificando-se aí uma não unanimidade salutar ao cinema.

Entre os filmes realizados sobre Kiarostami, tendo como mote Close-up, além de Close-up Long Shot, de Moslem Mansouri e Mahmoud Chokrollahi, destacamos Il giorno della prima de Close-up, de Nanni Moretti.

\footnotetext{
${ }^{49}$ Não por acaso, o produtor dos últimos filmes de Kiarostami é o francês Marin Karmitz, através da MK2, que já produziu filmes para o Irã, Romênia, México e até Estados Unidos.

${ }^{50}$ In: Alberto ELENA, Abbas Kiarostami, p. 290
} 
Nanni Moretti apresenta em sua filmografia títulos onde a discussão sobre o real mais do que pertinente, é obrigatória. Seu nome é associado ao de Kiarostami sempre que o tema surge, como comprova o curso sobre documentário que aconteceu no segundo semestre de 2006, promovido pela El Amante Escuela, do grupo que edita a revista El Amante, na Argentina. No programa do curso estão, ao lado de Close-up, Caro Diário e Aprile, de Moretti, ambos misturando ficção e não-ficção de maneira a confundir o espectador.

O curta-metragem Il giorno della prima de Close-up (1996) tem um simples enredo: Moretti, que é proprietário de uma sala de cinema em Roma, o Nuovo Sacher, está colocando Close-up em cartaz na cidade, com uma cópia apenas. O filme entra em concorrência com o blockbuster em desenho animado $O$ Rei Leão, que ocupa a maior parte das salas de cinemas. Como um David contra Golias, Moretti quer conseguir público para seu lançamento com o argumento de que se trata de uma reflexão importante sobre o próprio cinema e que Kurosawa havia dito que Close-up era extraordinário.

Para o espectador (não necessariamente um, no singular, mas seguramente poucos), talvez o principal argumento venha de uma solução fílmica do curta: a seqüência em que Nanni Moretti abre levemente a cortina do cinema e espia a última cena de Close-up. Ouvimos primeiro a música e só depois vemos Sabzian e Makhmalbaf na moto, observados pelo olhar reverente de Moretti. Uma homenagem do

\footnotetext{
${ }^{51}$ Solanas afirma que "(Kiarostami) é excessivamente valorizado pelo capricho e pelo terrorismo da crítica francesa e européia”. In: Teorema-Critica de Cinema, no 5, p. 24.
} 
italiano que, assim como Kiarostami, faz um cinema autoral e reconhece neste um diretor fundamental quanto a um cinema que pensa o cinema.

\subsection{Aparências}

Examinando a obra do cineasta iraniano, percebe-se que em seus longas e curtas metragens há uma inquietude permanente. Linguagem e estilo estão sempre em transformação, mesmo que, para o espectador comum, cinema iraniano seja "tudo a mesma coisa." ${ }^{, 52}$.

Em três filmes de épocas diferentes fica evidenciada a natureza experimental de Kiarostami. Close-up, Gosto de Cereja e Dez (Dah, 2002) são, a nosso ver, as obras que marcam esta inquietação, funcionando como matrizes ao utilizarem (testarem) recursos no terreno da linguagem: a quebra de registro ficção-documentário em Close-up, o rompimento da "quarta parede" somado à entrada do vídeo em Gosto de Cereja e a captação totalmente digital em Dez.

A complexidade está em como Kiarostami apresenta tudo isto e em como manipula o artifício que emerge da organização narrativa. A cada filme, o diretor vem sofisticando uma aparência de improviso. O que significa dizer que o resultado que

\footnotetext{
${ }^{52}$ A partir da observação em três edições do Fajr Film International Festival, de Teerã, podemos concluir que os chamados "filmes iranianos", expressão muitas vezes utilizada como se representasse um gênero, representam de fato o segmento do filme de arte e não passam de $10 \%$ do que é produzido naquele país. A generalização se deve ao fato de que a distribuição dos filmes iranianos se dá desde suas participações e premiações em festivais internacionais. Filmes que apresentam narrativa clássica são predominantes na produção comercial iraniana, porém, apenas atingem o mercado interno, além de países como Turquia, China e Índia. Segundo o próprio Kiarostami, no Irã o público está muito apegado à tradição do melodrama, à narrativa hollywoodiana. "Em meu país as pessoas ainda vão ao cinema para rir ou para
} 
temos na tela não se deve a improvisações, a acidentes, ou a um senso de oportunidade apurado que se abate sobre ele na hora da montagem. Kiarostami trabalha arduamente para que a fábula soe como expressão da realidade, quando de fato a realidade é apenas inspiração, fonte de elementos que entram num jogo de sedução entre fato e fantasia. Uma "fórmula Kiarostami" 53 entre documentário e ficção.

Consideramos Kiarostami canônico para o cinema moderno. A estranheza que seus filmes provocam, um tipo de originalidade que não pode ser assimilada, ou nos assimila de tal modo que deixamos de vê-la como estranha. Harold Bloom disse que "o cheiro da originalidade deve pairar sempre num aspecto inaugural de qualquer obra" ${ }^{, 5}$. Pois originalidade é o que não falta ao cineasta iraniano.

Um artista dos tempos de Maomé, recém-convertido ao islã, lamentou-se com Abbas, tio do Profeta, pois não sabia mais o que pintar (ou esculpir). Abbas o aconselhou a representar plantas e animais fantásticos, que não existem na natureza. ${ }^{55}$ Esta pequena história demonstra que ao artista foi dada a prerrogativa de inventar uma natureza e uma realidade que não existem, mas que "poderia existir". E não é isto que Kiarostami faz?

Em Onde Fica a Casa do Meu Amigo?, o protagonista algumas vezes sobe uma montanha em ziguezague. O espectador tem a impressão que para ser fiel ao real, optando inclusive por um plano-seqüência bem ao gosto da tradição realista, Kiarostami

chorar". In: Mehrnaz SAEED-VAFA \& Jonathan ROSENBAUM, Abbas Kiarostam - Contemporary Film Directors, p. 105-106.

53 A expressão "formule Kiarostami" é de Alain BERGALA no artigo "Les Pleins Pouvoirs du Cinema". In: Cahiers du Cinéma, mai, 2004, p. 45.

${ }^{54}$ In: Harold BLOOM, O Cânone Ocidental, p. 15.

${ }^{55}$ Citado por Titus BURCKHARDT, op. cit., p. 162. 
preferiu gastar muito mais tempo que o necessário para fazer o garoto subir e não interferir, assim, na topografia daquele lugar. Ledo engano. O ziguezague foi totalmente construído a partir de um desenho do diretor, como atestam making ofs e entrevistas do próprio Kiarostami. $\mathrm{O}$ mesmo acontece com o caminho em ziguezague que a personagem Tarareh faz em Através das Oliveiras (Zir-e Darakhatan Zeyton, 1994).

Em O Vento nos Levará (Bad Maara Jahad Bord, 1999), Kiarostami encarregouse de criar com o cenógrafo o caminho que uma inocente maçã percorria ao cair da varanda de uma casa. Como mostra o documentário $A$ week with Kiarostami, de Yuji Mohara, com making of das filmagens, horas de ensaio foram gastas, onde vemos a criação de pequenos sulcos no cimento para que aquele movimento "tão natural" ganhasse vida. Assim como, no mesmo documentário, vemos a equipe repaginando um "típico" vilarejo iraniano, para que ele ficasse limpo e bonito. "Fizemos tudo o que era possível para a vila parecer limpa, porque o filme não era sobre pobreza”, explica Kiarostami.

Já no documentário La Leçon de Cinéma, de Mojdeh Famili, também sobre $O$ Vento nos Levará, Kiarostami aparece experimentando o movimento de um osso nas águas de um riacho. Como o objeto, provavelmente o fêmur de uma ovelha, não realizava o percurso com a velocidade que Kiarostami queria, o cineasta produziu um falso osso, de material mais leve. Uma revelação que recebemos com certo espanto, pois tudo no filme parecia genuíno. Nenhum problema com o ilusionismo, próprio da arte, e por extensão, do cinema. Chamamos a atenção apenas para o elemento manipulador presente, na maioria das vezes, de forma insuspeita. 
A construção do plano-seqüência que Kiarostami assinou para Lumière \& Cia (Lumière et compagnie, 1995) é outro exemplo do apreço pelo ilusionismo, que em Close-up atinge o ponto máximo na cena do som. Lumière \& Cia reuniu 40 cineastas, entre eles Costa Gavras e Peter Greenaway, para que, com o intuito de homenagear os irmãos August e Louis Lumière, criassem um plano-seqüência com 52 segundos cada, utilizando no máximo três tomadas.

Ao som da ópera Carmem, o plano de Kiarostami abre e vemos um pedaço de manteiga sendo jogado em um frigideira. Uma secretária eletrônica é acionada (concluímos tratar-se deste aparelho, pelo ruído metálico típico), em voz over uma mulher (Isabelle Huppert) diz frases como: "Alô, sou eu, você está aí? Alô, alô..." Enquanto isto dois ovos são colocados a fritar, em um deles a gema se rompe. A ligação/mensagem é finalizada com um suspiro e a frigideira retirada do fogão.

Os primeiros segundos do plano, quando a manteiga em primeiríssimo plano começa a fritar, temos uma espécie de ilusão de ótica, que nos faz pensar que se trata de um negativo de filme queimando. A gema que se rompe e a mulher que não é atendida porque, supomos, a pessoa que frita o ovo não quer atender, poderia nos levar a algumas interpretações, mesmo que nenhum personagem de fato apareça.

Mas o universo dramático do filme estende-se para muito além de dois ovos e uma frigideira, pois as informações passadas pelo som são bastante ricas, embora plenas de feições provisórias. Kiarostami escamoteia o personagem que gera a ação, mantendoo fora de quadro, e nos ilude com uma suposta banalidade. Laura Mulvey chama esta predisposição de trompe l'oeil, “cinema que é ao mesmo tempo realidade e ilusão, 
gerando incerteza quanto ao que estamos vendo com nossos próprios olhos". ${ }^{56}$ Enquanto os outros cineastas mostraram trens, praças, prédios, sem uma radical provocação de sentidos, Kiarostami filmou algo com aparência de banal, que no entanto está carregada de poder simbólico, onde a ruptura de uma relação pode ser o centro deste simbolismo. Este plano seria como um teste para o ensaio que viria a ser Five Dedicated to Ozu. De todo modo, um de seus trabalhos mais ficcionais, justamente em meio a uma homenagem aos documentaristas avat la lettre, os irmãos Lumière.

A realidade, em Kiarostami, surge de uma noção do artístico, com ênfase na pintura (Kiarostami estudou Belas Artes). Seu olhar é de quem pensa telas de cinema como telas de pintura $^{57}$, determinando, com isso, seu senso estético e sua forma de criar, onde os exemplos de cenas em que exerce deliberado controle são infindáveis.

Sua relação com a fotografia é ainda mais séria, como podemos ver por este depoimento:

Há 25 ou 26 anos faço seriamente fotografia. Nem sempre sou cineasta, pelo contrário, realizo um filme a cada dois ou três anos, mas freqüentemente as regras narrativas me impedem de realizar certas imagens que tenho em mente. No cinema, infelizmente, é preciso contar uma história, ao passo que na fotografia somos mais livres, e uma estrada que se estende em direção a um certo lugar que não se vê pode abrir-nos um mundo desconhecido. Essa fotografia não conta uma história, mas nos deixa a liberdade de imaginá-la. Ante uma fotografia, o espectador pode fazer a sua própria viagem. Por isso, às vezes penso que a fotografia é uma arte mais completa; que uma fotografia, uma imagem estática, vale muito mais que um filme.

\footnotetext{
${ }^{56}$ In: Sight and Sound, “ Kiarostami’s uncertainty principle” p. 26, artigo já clássico para quem estuda a obra de Kiarostami, onde a autora afirma que Close-up é a obra chave para compreender a fascinação do diretor em transitar entre realidade e ilusão.

${ }^{57}$ Kiarostami fez trabalhos como artista plástico e é fotógrafo. 50 de suas fotos, que fizeram parte de uma exposição itinerante, podem ser observadas in: Abbas KIAROSTAMI \& Youssef. ISHAGHPOUR, Abbas Kiarostami - Duas ou três coisas que sei de mim. O real, cara e coroa.
} 
O mistério de uma fotografia permanece em segredo porque é sem sons, não há nada em seu entorno. Uma fotografia não conta uma história, e por isso está em perene transformação. Sobretudo, tem uma vida mais longa que a do filme. ${ }^{58}$

Em fotografia, chama-se latitude a propriedade do filme de registrar as diferenças entre luz e sombra de uma imagem dada. Pois o que podemos pensar é que o modus operandi de Kiarostami em Close-up não lança as diferenças entre luz e sombra, mas confunde o espectador sobre a quantidade de luz que está vendo. Emprega, para tanto, um considerável empenho, por exemplo, para que tudo pareça acaso e improviso. Um paradoxo que nos remete a Jean-Louis Baudry, quando afirma que o cinema vive da "diferença negada", pois o espectador vê imagens paradas, que alinhadas umas às outras dão a impressão de movimento. "O mecanismo da projeção permite suprimir os elementos diferenciais (a descontinuidade inscrita pela câmera), deixando em cena apenas a relação entre eles." ${ }^{, 59}$

\footnotetext{
${ }^{58}$ Abbas KIAROSTAMI, “A arte da inadequação”, Folha de São Paulo, Caderno Mais, 17 Out 2004.

${ }^{59}$ In: Ismail XAVIER (org), A Experiência do Cinema, "Cinema: efeitos ideológicos produzidos pelo aparelho de base", Jean-Louis BAUDRY,p. 390.
} 


\section{Close-up - A Narrativa}

Este capitulo apresenta um resumo do filme, a descoberta das duas versões de Close-up, a articulação da narrativa em flashbacks, o papel do tubo de spray e a ambigüidade de todos os personagens envolvidos.

\subsection{Sinopse}

Em um micro ônibus na cidade de Teerã, um desempregado, Ali Hussein Sabzian, está sentando ao lado da senhora Ahankhah. Ele lê o roteiro publicado do filme $O$ Ciclista, de Mohsen Makhmalbaf, chamando a atenção da mulher. Sabzian apresenta-se como Makhmalbaf, com o qual guarda semelhança física. Pouco a pouco Sabzian envolve toda a família Ahankhah num projeto de um filme que deverá ser rodado na confortável casa deles, e terá como protagonista o filho mais velho, Mehrdad, um engenheiro que não exerce a função, apaixonado por cinema. Depois de alguns dias hospedando Sabzian, que já havia conseguido algum dinheiro emprestado de um dos seus filhos, o senhor Ahankhah descobre que Makhmalbaf naquele momento estava no festival de Rimini, na Itália, onde $O$ Ciclista acabara de ser premiado. O impostor Sabzian é preso e processado. Após o julgamento, Sabzian encontra-se com Makhmalbaf, que o leva à casa dos Ahankhah para obter o perdão. 


\subsection{Procedimentos}

Por razões fortuitas, descobrimos no Irã que há duas versões do filme. A que foi exibida lá, lançada nos cinemas e em vídeo, traz o encontro de Sabzian com a senhora Mahrokh Ahankhah logo na primeira cena, antes dos créditos. Na versão distribuída no exterior, Sabzian só conhece a mulher no micro ônibus, durante as seqüências interrompidas do julgamento, em um flashback. Uma não-linearidade que torna a narrativa mais complexa. Para este fato, há a versão de que Kiarostami teria mostrado o filme na Alemanha, em Munique, e por acidente os rolos foram trocados, deixando a cena do micro ônibus em outra seqüência, dentro do julgamento ${ }^{60}$. Tendo gostado do resultado, o diretor teria remontado o filme para a distribuição no exterior. Fato ou ficção, o certo é que a não-linearidade corresponde a um desejo subentendido do público ocidental para com a obra de Kiarostami. E corresponde a uma certa expectativa envolvendo o chamado cinema de arte, de que os acontecimentos de uma história, se embaralhados, ganham um toque de sofisticação narrativa.

A existência da comercialização das duas versões, desconhecida para todos os autores aqui usados como fonte, leva-nos a optar pela análise da "versão exportação" de Close-up, pois, além de possibilitar diálogo maior com os leitores deste texto, é a versão que mais nos instiga. Afinal, e contrariamente ao padrão narrativo clássico, só vamos conhecer o "herói" quando o filme já tem 20 minutos e 17 segundos. Graças a este retardamento da entrada em cena de Sabzian, uma das seqüências que mais suscitaram interpretação tem um outro sentido. Trata-se da seqüência onde uma lata de spray é a

\footnotetext{
${ }^{60}$ In: Stéphane GOUDET, "Entretien avec Kiarostami: manipulations", Dossier Kiarostami, Positif, 442, p. 94. Uma curiosidade: a revista Positif tem uma relação umbilical com o cinema iraniano. O fundador da publicação e da Cinemateca Francesa, Henri Langlois, foi também o fundador da Cinemateca Iraniana, em 1958.
} 
protagonista. Ela rola durante 55 segundos ao lado do cordão da calçada, enquanto não sabemos o que acontece dentro da casa. Kiarostami protela os acontecimentos através do retardamento, um recurso conhecido da literatura e examinado com profundidade por Erich Auerbach em Mimenis. Nele, o autor diz que "O não preenchimento total do presente faz parte de uma interpolação que aumenta a tensão mediante $o$ retardamento."61

A propósito de um trecho bíblico (o encontro de Deus com Abraão), Auerbach diz: “(...) a viagem é como um silencioso andar através do indeterminado e do provisório, uma contenção do fôlego, um acontecimento que não tem presente e que está alojado entre o que passou e o que vai acontecer (...).”62 Este entre apresenta mútua relação com o plano do spray, que encerra um tempo suspenso, que está entre alguma coisa (passado e futuro que não é exatamente presente). Kiarostami está sempre entre algo, como veremos mais adiante, no capítulo Realidade em trânsito.

O plano do spray rolando, examinado sob outros ângulos no capítulo Objetos em movimento, acontece em seguida da chegada do repórter à casa dos Ahankhah com os policiais. O taxista que os trouxe fica esperando do lado de fora do carro (seqüência examinada com mais profundidade mais adiante). Na verdade, a câmera de Kiarostami também não entra na casa, o que frustra a expectativa do público, naquelas alturas já ávido por conhecer o tal impostor, cuja façanha havia sido descrita pelo repórter ao motorista de táxi.

\footnotetext{
${ }^{61}$ In: Erich AUERBACH, Mimenis, p. 3. O autor refere-se à cena da Odisséia, onde a identidade de Ulisses é descoberta pela criada. Toda a cena com a empregada funciona como um elemento retardador do encontro de Ulisses com a esposa.

${ }^{62}$ Idem, p. 7.
} 
Ao espectador do filme e ao taxista, Kiarostami oferece a paisagem de muros altos das casa vizinhas, que funcionam como um símbolo concreto de "não ultrapasse". Para Gilberto Perez, em The Material Ghost, Close-up "nos conscientiza de que o mundo atual não nos concede entrada especial nas histórias tanto quanto na casa dos privilegiados" ${ }^{63}$. E segundo Perez, isto é como o naturalismo conduz ao modernismo: no mundo atual nós não temos acesso privilegiado ao que acontece. Perez não faz referência às experiências na linha reality show onde, em princípio, o público teria acesso ao que acontece, mas acaba respondendo a questão ao afirmar que nós devemos colocar em xeque os meios empregados pela arte para representar o mundo.

Apesar deste procedimento que escancara a idéia de que há uma construção narrativa em curso, e de que o diretor tem o poder absoluto de como se dá esta construção, o aparato de Close-up nesta cena envolvendo a espera não é exibido. Bem como nas seqüências onde Kiarostami reconstitui os momentos que antecedem a prisão de Hussein Sabzian. Ele o faz como se tivesse com uma câmera escondida portada por algum deus onisciente, que não diz tudo o que sabe. Ou seja, o tratamento é de ficção.

Já em outras cenas, Kiarostami expõe o aparato, na linha do cinema-verdade de Jean Rouch, justamente nos momentos em que a câmera deveria estar ali para flagrar o instante do real. Além de, em algumas cenas, Kiarostami falar dentro e fora de quadro (off e in), na cena 12, que mostra o julgamento, após aparecer a claquete e o microfone direcional, o diretor dá instruções a Sabzian como quem orienta um ator iniciante: "Nós vamos trabalhar com duas câmeras. Uma, vai enquadrar o plano geral de todos na sala e outra estará sempre em você, em close-up. Você sabe o que é um close-up?"

\footnotetext{
${ }^{63}$ In: Gilberto PEREZ, The Material Ghost - Films and their medium, p. 263.
} 
Com esta instrução, Kiarostami acaba por afastar-se do documentário jornalístico. Isto porque, se por um lado procura jornalisticamente dar voz às duas partes, denunciante e denunciado, ou vítima e criminoso, na medida em que o close é oferecido apenas e explicitamente a Sabzian, Kiarostami está sendo parcial e somos levados a considerar que interessa mais ao diretor conhecer o antípoda da história. O recurso "artificial" do close-up em Sabzian levou Kiarostami a reconhecer mais tarde que não é este cinema que defende. Ele disse que algumas vezes é preciso afastar a lente e olhar atenciosamente para descobrir detalhes ao invés de optar por um close-up. ${ }^{64}$

Em outro procedimento do filme, Kiarostami aproxima-se ainda mais do tratamento ficcional através da decupagem. Trata-se do plano, um contra-plongé, que mostra Sabzian sentado na sala dos Ahankhah. Lá fora, uma movimentação indica que algo estranho acontece, o senhor Abolfazl Ahankhah e um dos filhos recebem alguém. Nós, os espectadores, já sabemos que é a polícia que chegou para prendê-lo, pois a cena foi a segunda do filme, mas não tínhamos ainda o ponto de vista de Sabzian.

Este contra-plongé funciona então como o último momento de Sabzian vivendo ainda "engrandecido" a fantasia de ser Makhmalbaf. Em sua decupagem elaborada, Kiarostami posiciona a câmera de forma oposta para conflagrar a queda de Sabzian: quando os policiais entram na sala para prendê-lo - e só aí ele entende o que estava acontecendo -, a câmera mostra Sabzian no fundo desta sala, de forma a parecer extremamente pequeno e de certo modo trágico, numa expressão de auto-sacrifício. Se os fiéis açoitam-se em Karbala em memória do Imã Hussein, Sabzian o faz em nome da

\footnotetext{
${ }^{64}$ Film International. "Debates with Kiarostami, Iranian movie director”, vol. 3, no 1, pp.46-49.
} 
causa do cinema, como veremos mais adiante. Simbologias associadas, neste mesmo espaço temporal, só que na montagem não-linear visto antes, o tubo de aerosol despenca sugerindo a queda do personagem.

A articulação em flashbacks e a capacidade de desenvolver mecanismos do documentário na ficção e mecanismos da ficção nos momentos documentais, revelam um refinamento narrativo que deram a Close-up papel de destaque na história do cinema.

Sob alguns aspectos, estes mecanismos de Close-up revelam parentesco com o jornalismo literário (também conhecido como new journalism). Deu-se o nome de jornalismo literário para o resultado de uma apuração rigorosa de fatos acontecidos. Truman Capote é seu expoente mais celebrado em função do livro A Sangue Frio (1966), onde, após horas de entrevistas, ousava descrever o pensamento dos assassinos Perry Smith e Dick Hickock.

Tom Wolfe deu seguimento à perspectiva subjetiva do jornalismo e teorizou a respeito. Em Radical Chique e o Novo Jornalismo, Wolfe afirma que o importante neste modo de fazer jornalismo é trazer o leitor não só para dentro do ringue, mas para dentro do ponto de vista dos lutadores. É isto, num certo sentido, o que faz Kiarostami na cena em que coloca Sabzian sozinho na sala dos Ahankhah. Sabemos, pelas entrevistas, que para apurar os fatos o diretor conversou com os envolvidos no sentido de rememorar os acontecimentos para que ele propusesse, à dramatização, o que de mais importante tinha se passado sob o ponto de vista de Sabzian. 
O que sentiu Sabzian quando ficou sozinho na sala e espiou pela janela os policiais conversando com o senhor Ahankhah, não sabemos. O que temos é uma apuração de fatos exposta por Kiarostami. Assim como não podemos conhecer o pensamento dos assassinos de A Sangue Frio, de Capote. Confiamos em quem está apresentando a história, com a certeza de que não se trata de apenas um mediador, mas alguém que (re)cria fatos. Nossa hipótese, como demonstramos alguns parágrafos atrás, é de que Kiarostami está fazendo ficção nesta cena. Mas na teoria proposta por Bill Nichols, este momento de solidão de Sabzian o filme estaria indentificado como documentário dentro do que ele chama de realismo psicológico:

O realismo psicológico implica a transmissão dos estados intimos dos personagens e atores sociais de maneira plausivel e convincente. Ansiedade, felicidade, raiva, êxtase, etc. podem ser tratados e transmitidos realisticamente. Consideramos realística a representação desses estados quando sentimos que a vida interior de um personagem foi transmitida de modo eficiente, mesmo se, para isso, o diretor teve de recorrer à inventividade, prolongando um plano mais do que o usual, adotando um ângulo revelador, acrescentando uma música sugestiva ou sobrepondo uma imagem ou seqüência à outra. ${ }^{65}$

Para alcançar a reconstituição "psicológica dos fatos", Kiarostami conta com a lembrança dos personagens. Pois a investigação sobre a verdade no contexto de um docudrama, de um filme que reproduz o que aconteceu, também passa pela construção deste fato através da memória de quem vivenciou. Pesquisas sobre memória e esquecimento, desenvolvidas pelos cientistas Ivan Izquierdo e Martín Cammarota, do Centro de Memoria do Instituto de Pesquisas Biomédicas da PUCRS, indicam que cada

\footnotetext{
${ }^{65}$ In: Bill NICHOLS, Introdução ao Documentário, p. 128
} 
vez que uma lembrança é trazida à consciência, torna-se instável e se modifica. ${ }^{66} \mathrm{O}$ processo ocorre porque ao recordar, tiramos a imagem do seu recanto e a manipulamos, agregando a ela as emoções e os pensamentos do momento. Nosso cérebro teria muitas memórias e as misturaria o tempo todo, podendo até incorporar memórias falsas.

Naturalmente, o tempo que passou desde que Sabzain se fez passar por Makhmalbaf, sua prisão até o julgamento e a reconstituição dos fatos, foi pequeno (menos de 2 meses). Mesmo assim, é um processo de recordar o que foi dito, por várias pessoas, cada uma com seu ponto de vista. Inclusive recordar momentos em que a pessoa estava só num ambiente, como o que antecede à prisão e Sabzian está sozinho na sala dos Ahankhah. Então, é justo pensar que a pureza do fato em si é volátil, se perde nos escaninhos na memória e propicia a tendência à manipulação desta.

Esta manipulação quando tem o objetivo de ser exposta ao universo midiático, nos leva a pensar que a memória dos atores envolvidos em Close-up pode ser circunscrita no que a ensaísta argentina Beatriz Sarlo chama em seu livro Tempo Passado $^{67}$ de "teatralização da memória". Nele, Sarlo defende a idéia de que a testemunha não é infalível e questiona a crescente criação de museus e o "estado de memória", que vive hoje a Europa, reconstruindo paisagens e aldeias supostamente originais. Neste contexto, segundo ela, prevalece a noção de teatralização da memória.

Portanto, estamos lidando com a possibilidade não só da manipulação pensada e objetiva de diretores, como da manipulação a que está sujeita a memória de personagens

\footnotetext{
${ }^{66}$ Para mais detalhes ver artigos dos cientistas citados nas revistas Trends in Neuroscience (Disponível em: www.trends.com/tins), set., 2006, e Neuron, jan. 2007 (Disponível em: www.neuron.org).

${ }^{67}$ Beatriz SARLO, Tempo Passado. São Paulo: Companhia das Letras, 2007.
} 
de docudramas. Mas o espectador, consciente ou não destas possibilidades, suspende sua crença no que está vendo?

Analisando filmes como Nanook (Robert Flaherty, 1922), Na Linha da Morte (Errol Morris, 1988) e Basquete Blues (Steve James, 1994) que reconstituem eventos acontecidos, Bill Nichols diz que todas estas escolhas, como usar música, buscar locações diferentes de onde os fatos aconteceram "representam táticas dos cineastas para produzir um efeito sobre o público. Talvez equivalham a uma ciência imperfeita, mas são parte integrante da representação documental"68. Nichols vai além, afirmando que quando acreditamos em alguma coisa sem sabermos o porquê de estarmos acreditando, esta coisa se torna fetichismo ou fé. "Com freqüência o documentário convida-nos a acreditar piamente que aquilo que vemos é o que estava lá”, ${ }^{69}$. Embora Close-up não se apresente como documentário enquanto gênero (nos créditos finais, Kiarostami denomina de "atores", inclusive Sabzian e ele próprio, mesma estratégia, aliás, de Wim Wenders em Nick's Movie), não deixa margem para dúvidas: busca este ato de confiança, de fé do espectador em relação à imagem apresentada. E fé corroborada pela manutenção de defeitos técnicos, como veremos mais adiante.

Tentando desvendar a estratégia retórica operacional de Abbas Kiarostami, e se preferirmos enquadrá-lo em uma categoria, recorreremos a Bill Nichols novamente. O teórico criou padrões de representação nos quais a maioria dos documentários se organiza. Entre os primeiros padrões de Nichols estão o Expositivo, Observacional, Interativo e Reflexivo $^{70}$.

\footnotetext{
${ }^{68}$ In: Bill NICHOLS, Introdução ao Documentário, op. cit., p. 120.

${ }^{69}$ Idem.

${ }^{70}$ Ver capítulo "Documentary modes of representation". In: Bill NICHOLS, Representing Reality.
} 
Poderíamos enxergar Kiarostami em Close-up como o tipo Observacional do cinema direto, pois não usa voz over, nem música (exceção para o final). No entanto, no item que Nichols prevê omissão de qualquer elemento pré e pós-produção, o diretor já não se encaixa. Aproxima-se, talvez, da categoria Interativo ao dirigir como Jean Rouch, de forma a participar da ação em algumas cenas. Em parte, também poderia ser Reflexivo, como Michel Moore, inserindo perguntas-comentários (no tribunal). Por outro lado, poderia ser visto como Expositivo, porque esconde contradições internas, como o fato de não revelar que Sabzian não queria fazer o filme (ver mais adiante).

Assim, Kiarostami assume várias formas de narração - narração no sentido dado por Gérard Genette, designando "a sucessão de acontecimentos, reais ou ficcionais, que fazem o objeto do discurso, e as diversas relações de encadeamento, de oposição, de repetição, etc." ${ }^{, 1}$ - deste argumento que surgiu a partir de um fait-divers. O diretor descobriu a notícia sobre um crime publicada em uma revista iraniana (Soroush Magazine), entrevistou os envolvidos, filmou a audiência de julgamento e só então escreveu o roteiro, reconstituindo os fatos para os próprios implicados interpretarem.

Longe de ser um mero desfilar de acontecimentos, em que o cinema seria apenas o suporte para contar a história, Close-up está ontologicamente ligado ao cinema. Seu enredo não existiria não fosse o cinema, porém, não é um filme apenas sobre o cinema, o que seria reduzi-lo a um sistema de imagens e sons. Close-up é também sobre como o homem se vê, como gostaria que o vissem, como gostaria de ser.

\footnotetext{
${ }^{71}$ In: Gérard GENETTE, Figures III, “ Discours du récit-essai de méthode”, p. 71.
} 


\subsection{0 mártir desempregado}

Sabzian, o protagonista, transformou-se em notícia porque foi preso pelo crime de falsa identidade. Na tentativa de compreendermos o processo comportamental de Sabzian, devemos trazer o contexto sociológico do drama.

Hussein Sabzian carrega o nome do mártir de Karbala, o filho de Ali, como já referimos no capítulo Introdução/Karbala. E embora isto não chegue a ser uma coincidência relevante, pois se trata de um nome muito comum no Irã ${ }^{72}$, o perfil de homem torturado pela vida, o associa ao personagem trágico do islã xiita. O Imã Hussein, oprimido e morto por um sunita, sempre teve sua memória reverenciada pelos xiitas, e durante os episódios que antecederam à Revolução Islâmica, o culto a ele cresceu ainda mais, ao ponto de se tornar um símbolo do povo oprimido pelo xá Reza Pahlevi. Este vínculo a Hussein, o mártir, pressupõe um vínculo ainda mais sagrado, que é com o profeta Maomé, pai de Hussein. A mãe de Sabzian, presente ao julgamento, rompe o ritual e dirige-se diretamente ao juiz lembrando que o filho é descendente de Maomé. Numa sociedade regida pela sharia, ser descendente do fundador do islamismo significa que aquele sujeito deve ser respeitado. O próprio turbante preto usado pelos religiosos, incluindo o ex-presidente Khatami, existe para indicar justamente esta descendência.

No aspecto mais visível e concreto de sua situação na sociedade iraniana, Sabzian faz parte de uma minoria étnica, o que fica explicitado na cena do julgamento, quando a mãe do personagem se expressa em um dos dialetos turcos. Este aspecto foi 
trazido pelo crítico de cinema do Chicago Reader, Jonathan Rosenbaum, autor de vários textos sobre Kiarostami. Rosenbaum vê Sabzian como um marginalizado a partir desta condição de "minoria étnica". ${ }^{73}$ Chamamos atenção, no entanto, para o fato de que a abastada família Ahankhah também fala um dialeto turco, mais exatamente o azeri, do Azerbaijão. Na entrevista que faz com eles, em Close-up, Kiarostami chega a pedir para que voltem a falar farsi porque ele não compreende o que estão dizendo. Não podemos esquecer também que o senhor Badii, o suicida de Gosto de Cereja, igualmente falava um dialeto e não havia, aparentemente, implicações sociais para seu suicídio. Convém referir também que a língua turca falada em várias regiões do Irã opera com inúmeros dialetos. Pessoas da fronteira com a Turquia e fronteira com o Azerbaijão, por exemplo, falam diferentes dialetos, os quais somente um iraniano poderia reconhecer, nos filmes, a origem do personagem e determinar o quanto ele representa uma minoria. Mas o multiculturalismo em Kiarostami seria assunto para uma outra tese.

O que não podemos negligenciar, para melhor compreendermos Sabzian, é o contexto histórico-social do episódio. Desempregado, Sabzian é uma vítima da crise do pós-guerra. Não esqueçamos que Close-up foi rodado em 1989 (lançado em 1990) e a guerra Irã-Iraque (1980-1988) recém havia terminado. Nela, estima-se que mais de 1 milhão de pessoas, entre os dois lados, tenham morrido. Praticamente todas as famílias iranianas têm algum parente, ou conhecido, morto ou ferido em função da guerra ${ }^{74}$. Até hoje o país não se recuperou dos milionários gastos com o conflito. Mesmo sendo um dos maiores produtores de petróleo do mundo, em função da guerra e dos embargos comerciais impetrados pelos Estados Unidos, o desemprego atingiu milhões de

\footnotetext{
72 Kiarostami também dá o nome de Hussein para os personagens centrais dos filmes The Experience (Tadjrebeh, 1973), A Suit for Wedding (Lebosi bara-ye Arusi, 1976) e Através das Oliveiras (Zir-e Darakhatan Zeyton, 1994).

${ }^{73}$ In: Mehrnaz SAEED-VAFA \& Jonathan ROSENBAUM, op. cit. , pp. 84-85
} 
trabalhadores como Sabzian. Portanto, não devemos ignorar que há um drama social por trás da motivação do personagem, que poderia provocar uma certa indulgência por parte dos Ahankhah, do juiz e mesmo de Kiarostami. Hormuz Kéy, em Le Cinéma Iranien: L'Image d'une Societé en Bouillonnement, também lembra que, ao identificar-se com os miseráveis dos filmes de Makhmalbaf, Sabzian culpa a sociedade iraniana e de certo modo a própria Revolução Islâmica, que em 1979 derrubou a monarquia com a promessa de justiça social (os grupos comunistas, como o marxista-leninista Fedaim, apoiaram Khomeini), e naufragou nas intenções.

A compreensão da figura de Sabzian, suas ações e conseqüências, mais do que associada ao fato de ser uma "minoria étnica", deve ser encontrada na sua condição de desempregado, possivelmente mais um dos "camponeses perdidos na cidade"75. A propósito, Pasolini apontava que o olhar de um camponês "vê um tipo de realidade diferente daquela que vê o olhar de um burguês culto."76

Nos antecedentes que geraram a Revolução, Teerã sempre aparece como a cidade que recebia a grande massa de imigrantes expulsos do campo pela modernização do país. O "eldorado" urbano representado pela capital, absorvia estes imigrantes criando favelas e ordas de desempregados. Como podemos depreender das entrevistas dos conhecidos de Sabzian, no anexo que reproduz parte do documentário Close-up Long Shot, de Moslem Mansouri e Mahmoud Chokrollahi, Sabzian trabalhou como gráfico, mas não tinha qualificação para isto.

\footnotetext{
${ }_{75}^{74}$ Para mais detalhes ver Rouhi SHAFII, Scent of Saffron-Three Generation of a Iranian Family.

${ }^{75}$ A expressão indica "a persistência e a inadaptação das estruturas mentais rurais à nova situação de imigrantes urbanos no Irã". Cf. Gilles KEPEL, citando F. Khosrokhavar. In: Jihad - Expansão e declínio do islamismo, p. 167.
} 
Mesmo depois de "famoso" como Makhmalbaf, não encontrou a glória, sequer uma razoável justiça social, sobrevivendo de biscates e da caridade. "Meus sonhos não foram realizados", diz ele no documentário Close-up Long Shot.

Sabzian é, de fato, um excluído do processo revolucionário. Como, no decorrer do filme, ele não faz alusão direta à religião, depreendemos que, se foi um militante contra o regime do Xá, não o foi pelas vias dos grupos religiosos que apoiavam Khomeini; se foi um militante, não obteve um cargo público como muitos, como não foi soldado na guerra contra o Iraque (a informação necessariamente viria à tona, seja no filme, seja nos documentários e entrevistas, porque ex-soldados gozam de aposentadorias ou suporte econômico de fundações geridas pelo clero criadas para este fim), e estava na idade de sê-lo, é fácil concluir que Sabzian vivia como um pária, antes de "ser Makhmalbaf".

\subsection{Influência midiática}

É nesta circunstância descrita que Sabzian se torna um admirador dos filmes de Mohsen Makhmalbaf, o mais popular cineasta iraniano, especialmente do título que mostra o desespero de um desempregado para conseguir dinheiro, O Ciclista (Baysikelran, 1987) ${ }^{77}$. É em função do amor ao cinema que a família recebe o falso Makhmalbaf (Sabzian mente que está procurando locações para seu próximo filme); é por conta da natureza cinefílica do delito que Kiarostami se interessa pelo caso; por fim, é por gostar

\footnotetext{
${ }^{76}$ Pier Paolo PASOLINI, “A Poesia do Nôvo Cinema”. In: Revista Civilização Brasileira, no 7, p. 279.

${ }^{77}$ O Ciclista narra a história de um refugiado afegão que vive no Irã. Desesperado para pagar o hospital em que a mulher está internada, ele se aparesenta em uma praça em cima de uma bicleta, por uma
} 
de cinema que o hadj Agha, o juiz, permite que o julgamento seja filmado. $\mathrm{O}$ impressionante poder catalisador do cinema como espetáculo, cuja força no Irã equivale à televisão no Brasil, é a lógica que perpassa todo o jogo de motivações.

A primeira vista, é Sabzian quem sofre do mal da sociedade do espetáculo, ao querer pertencer ao universo do cinema a todo custo. Mas não podemos esquecer que a família Ahankhah igualmente é tomada pela influência midiática, do Zeitgeist, do "espírito do tempo" relacionado ao poder das imagens reprodutíveis de que Walter Benjamin falava. Embora no Irã não haja (ainda) reality shows, a televisão, com o "advento" das antenas parabólicas (colocadas ilegalmente) começa a ter, mesmo que de forma ainda muito incipiente, um papel similar ao que tem nos países como o Brasil. Mas, de fato, as celebridades ainda estão mais relacionadas à sétima arte (e ao futebol). Atrizes de cinema como Nikki Karimi (cachê de 20 a 30 mil dólares por filme), estão sempre dando entrevistas e autógrafos. Naturalmente, Viva o Cinema (Salaam Cinema, 1995) é a melhor medida desta vontade de fazer cinema. Makhmalbaf colocou um anúncio no jornal pedindo 100 atores para um novo filme e 5 mil pessoas se apresentaram para fazer o teste. Um clima que existia sobretudo na Itália à época no neo-realismo e que acabava resultando em frustração, como observa Mariarosaria Fabris:

A utilização dessas pessoas tiradas das ruas trouxe aos cineastas não poucas preocupações éticas, pois muitas delas sacrificavam o que tinham para poder ingressar no cinema, ou então, uma vez ingressadas, esperavam consolidar uma carreira, o que, na maioria dos casos, não ocorreu. ${ }^{78}$

semana, sem dormir, num desafio semelhante ao do filme $A$ Noite dos Desesperados (They Shoot Horses, Dont't They?, Sidney Pollack, 1969).

${ }^{78}$ In: Mariarosaria FABRIS, O Neo-Realismo Cinematográfico Italiano, p. 83. 
E no contexto do espetáculo, cabe notar que ele envolve uma demanda: a predisposição para ser outro e assim se legitimar como indivíduo. Da família, passando pelo impostor, até o juiz e o próprio Kiarostami, todos interpretam um personagem. Os Ahankhah atuam como vítimas onde em função da vaidade, do fascínio pela imagem, aceitam a participação no filme, numa espécie de reality show de exposição pública, onde parecem redefinir Descartes: "eu tenho uma imagem, logo, existo"79; Sabzian atuava para a família, passou a atuar para Kiarostami em duplo papel (como ele próprio e como Makhmalbaf) porque, concluímos, é esperto o suficiente para saber que o filme poderia ajudá-lo a ser absolvido. Afinal, se o cinema o tornou respeitado (“A família fazia tudo o que eu pedia. Eu falava para eles tirarem um armário do lugar, e eles faziam”, diz Sabzian no filme), porque não poderia influenciar a Justiça?

O motorista de táxi também não parece confortável na função. Comenta com o repórter que era militar, piloto de avião durante a guerra Irã-Iraque. E quando espera do lado de fora da casa pela prisão de Sabzian, ouvimos o som de um avião, seu olhar dirige-se para o céu num gesto de saudosismo, de alguém que preferia ser outro, mesmo que ele mesmo no passado.

O juiz, por seu turno, finge que por representar o rígido sistema judiciário iraniano, concebido dentro da sharia,' estaria imune à sedução do espetáculo audiovisual, num contexto religioso que interdita(ria) a divulgação de imagens. Mas participa do filme, fazendo concessões inimagináveis no sistema jurídico. Portanto, não há inocentes frente à câmera de Kiarostami.

\footnotetext{
${ }^{79}$ A variação da máxima de Descartes "Cogito ergo sum", é de Kiarostami, em entrevista a Stéphane GOUDET, Positif, 442, op. cit., p. 96.
} 
O repórter que deflagra o episódio com a publicação da matéria sobre a farsa é o que Kiarostami trata sem maior cerimônia. Farazamand aparece como alguém que definitivamente não se limita ao papel de repórter. Ele diz que queria ser Oriana Fallaci, a jornalista italiana célebre nos anos 70 e 80, especialmente porque conseguiu uma polêmica entrevista com Khomeini ${ }^{80}$. Farazamand lembra inclusive um clown quando corre pela vizinhança em busca de um gravador para registrar a prisão.

O que temos na tela é o mesmo raciocínio valendo inclusive para Abbas Kiarostami. Afinal de contas ele está interpretando o papel daquele que veio para dar voz a todos. Uma espécie de Deus, não pelo seu caráter místico, propriamente, mas pelo poder imperativo de autor, inclusive, e principalmente, quando nega este poder. Ou finge negar. É Deus quando logo nas primeiras cenas pede ao juiz que altere a data do julgamento para facilitar o cronograma de filmagens. É Deus quando interfere em cada corte na montagem - chegando a assumir a moviola -, edificando o seu discurso sobre os fatos. Kiarostami é produtor do real, gerenciador do simulacro.

Se todos encontraram seu papel a desempenhar neste espetáculo, vale ainda aprofundar a análise sobre Sabzian. No livro A Representação do Eu na Vida Cotidiana, Erving Goffman diz que quando alguém desempenha um papel, está querendo que seus observadores o levem a sério. "Pede-lhes para acreditarem que o personagem que vêem no momento possui os atributos que aparenta possuir, que o papel que representa terá as

\footnotetext{
${ }^{80}$ Curioso notar que, mesmo conhecida, vários autores que citam a repórter à propósito de Close-up erram ao nomear Oriana Fallaci, que em Hormuz KÉY (op. cit) aparece como "Ariana Flacci” e em François NINEY, como "Ornela Falacci" ( "Gros plan sur Close-up - Kiarostami, le passeur". Cahiers du cinéma, $\mathrm{n}^{\circ}$ 450, dez. 1991) e em Jean-Claude BERNARDET como "Ornella Falacci" (Caminhos de Kiarostami). Oriana Fallaci morreu na Itália no dia 14 de setembro de 2006 e todos os jornais destacaram como um dos seus grandes feitos a entrevista com Khomeini, no início da Revolução, uma das poucas mulheres
} 
conseqüências implicitamente pretendidas por ele e que, de um modo geral, as coisas são o que parecem ser." 81

A partir desta definição de Goffman, podemos inferir que Sabzian defende um duplo papel, enquanto representa ser Makkmalbaf e enquanto Sabzian, aquele que fez tudo por amor ao cinema. Não esquecendo que o que vemos na tela já é um Sabzian descoberto, interpretando Makhmalbaf para um público que sabe que ele não é Makhmalbaf. Nossa tendência, como espectadores, é acreditarmos que a sinceridade de sua performance está nos momentos em que ele é simplesmente Sabzian. Goffman, inclusive, usa o termo "sincero" para definir o indivíduo que acredita na impressão criada por sua representação, e o termo "cínico", para o indivíduo que não crê em sua própria atuação e também não se interessa se o público acredita nele.

Embora o público não tenha tido acesso à performance de Sabzian enquanto Makhmalbaf (só a família Ahankhah teve), é possível ir mais fundo neste jogo de representações utilizando os conceitos de Goffman. O Sabzian fora da tela, que se fez passar por Makhmalbaf, teria sido um cínico que brincou com a crença do público que o estava levando a sério (os Ahankhah). Goffman diz que nem todos os atores cínicos querem iludir sua platéia, "um indivíduo cínico pode enganar o público pelo que julga ser o próprio bem deste, ou pelo bem da comunidade, etc." 82 Goffman também fala nos cínicos que são levados a iludir seu público, pois este mostra grande desejo disto:

Os médicos que são levados a receitar medicamentos inócuos para tranqüilizar os doentes; os empregados de postos de

estrangeiras a quem Khomeini deu entrevistas. Em 2002, ela publicou o livro “A raiva e o orgulho", pelo qual estava sendo processada por difamar o islã.

${ }^{81}$ In: Erving GOFFMAN, A Representação do Eu na Vida Cotidiana, p. 25.

${ }^{82}$ Idem, p. 26. 
gasolina que resignadamente verificam e tornam a verificar a pressão dos pneus para ansiosas senhoras; os vendedores de calçados que vendem um sapato de $n^{o}$ diferente mas que dá no pé da freguesa e dizem a ela que é do tamanho pedido, todos estes são profissionais cínicos, cujo público não lhes permitirá serem sinceros. ${ }^{83}$

O próprio Kiarostami, ao falar sobre a família Ahankhah, os vê sob a perspectiva do sujeito que quer ser enganado. Pensa, inclusive que ele, Kiarostami, é parecido com a família e usa um termo ainda mais forte que enganado. O cineasta fala em abusado: "Eu diria que às vezes me deixo abusar também. Às vezes até quero ser abusado." ${ }^{\natural 4}$

Mas a pergunta que deve ser feita em torno do proposto por Goffman é: Kiarostami, enquanto indivíduo que representa um papel, é cínico ou sincero? A tentativa de responder a questão fica em suspenso para o capítulo $O$ Julgamento, pois somente após a análise do som e da sessão do tribunal o leitor poderá se colocar no papel do público.

\subsection{Narrador}

Demonstrando a complexidade do filme, Kiarostami imprime rigor à narrativa, ao tratar os acontecimentos pré-julgamento como ficção-encenação e os pós-julgamento como documentário. Assim, as seqüências no interior da casa da família Ahankhah, Kiarostami não lança mão do disnarrativo. Ou seja, não contesta a narrativa exibindo o material de filmagem no espaço arbitrado como diegético. Nas cenas tomadas dentro da

\footnotetext{
${ }^{83}$ Idem. .

${ }^{84}$ In:Hormuz KÉY, Le Cinéma Iranien: L'Image d'une Societé en Bouillonnement, op. cit,. p. 165.
} 
casa é como se Kiarostami não estivesse lá. Afinal, pela cronologia dos fatos, ele "não poderia ter estado lá", pois Sabzian ainda não tinha sido preso e, portanto, utilizando um esquema da teoria da "focalização interna" proposto por Gérard Genette, onde o narrador só diz o que o personagem sabe, não havia sentido o aparato do filme ter entrado na casa antes disto.

Porém, podemos enxergar como uma quebra deste rigor narrativo, o fato de que Kiarostami acompanha o jornalista (Hossain Farazmand) e os policiais (Mohammad Ali Barrati e Davood Goodarzi) no táxi, até a casa onde vão prender Sabzian. Isto é, na cronologia dos acontecimentos, a equipe também não poderia estar nesta cena, mas estava. Outra quebra, ou fuga da focalização interna, é a cena no micro ônibus, quando a senhora Ahankhah conhece Sabzian. Kiarostami também não poderia estar presente naquele momento, mas estava.

Na verdade, a opção de não entrar na casa quando os policiais chegam, pode muito bem corresponder a um propósito do diretor de fazer suspense, de não apresentar seu personagem logo de saída, de deixar o espectador apreensivo com o que poderia estar acontecendo lá dentro. O recurso utilizado nesta cena para fazer parar o tempo é o de lançar um elemento novo para distrair a atenção do espectador e, além disto, fazer uma experiência de tempo estendido. O taxista (Hooshang Shamaei) que espera em frente à casa sai do automóvel, mexe no lixo na beira da calçada e chuta uma lata de spray. A câmera acompanha por quase um minuto esta lata rolar rua abaixo. Com tanto tempo dedicado a ela, a lata transforma-se em personagem instantâneo. Qual o objetivo? Vamos examinar o papel da lata de spray mais adiante. 
Mas dando crédito à lógica de Kiarostami de "não estar onde não poderia ter estado", referente à cena da chegada dos policiais, o tratamento em equivalência narrativa que o diretor dá à seqüência da falha do som é de documentário sem recriação de fatos, sem docudrama, mas sim de flagrante da realidade. De acordo com esta divisão ficção-documento, seria legítimo, no encontro de Sabzian com Makhmalbaf, exibir o aparato do cinema para o espectador. O problema, a ser explorado em seguida, é que se trata de um acidente montado. O que parece falha, é artifício pertencente a outro universo diegético, mas ainda assim diegético, no sentido de que se trata de uma encenação indexada à mise-en-scène como um todo. $\mathrm{O}$ mesmo acontece na cena do tribunal, supostamente documental. 


\section{Objetos em movimento}

Como a lata de spray dialogoa com outros objetos em movimento nos filmes de Kiarostami, especialmente Five, e como a natureza (e a morte) relacionam-se com o spray.

Ismail Xavier, respondendo a uma pergunta sobre a questão do tempo no cinema, defendeu que:

(...) uma das questões cruciais que o artista enfrenta hoje é a necessidade de se contrapor a essa temporalidade e produzir uma experiência capaz de deslocar o espectador para outro tempo e se desdobrar para uma outra qualidade de experiência. Neste sentido, a obra prima dos últimos tempos é Five. ${ }^{85}$

Five, homenagem a Yasujiro Ozu, o mestre japonês da delicadeza, da sutileza, que filmava o cotidiano usando planos fixos, é uma experiência de apurado rigor formal, que transformam cada uma das cinco partes em espécies de versículos.

Embora opere com a câmera parada na maior parte do tempo, Kiarostami retrabalha o som inteiramente e filma objetos, pessoas e animais que se deslocam. São cinco partes (ou cinco curtas, ou cinco planos, como se preferir). Na primeira parte temos um toco, parte de um galho de árvore, que é empurrado pelas ondas do mar e racha em dois. Na segunda temos vários cães ${ }^{86}$ vistos à distância, que estão como que a

\footnotetext{
${ }^{85}$ In: "Intuição e sensibilidade", Revista Teorema - Crítica de Cinema, no 8, p. 27.

${ }^{86} \mathrm{O}$ uso reiterado dos cães nos filmes de Kiarostami chama a atenção. Em $O$ Pão e o Beco um vira-lata é o personagem motivador de toda ação. Em Five, cães formam o principal elemento da segunda parte e latidos são ouvidos na última parte. Em Close-up, ouvimos latidos de cães no momento crucial, em que Sabzian será preso. Esta atitude do diretor pode ser considerada herege, pois num país que segue o Corão, como o Irã, o cão é mal-visto. "Manter cães dentro de casa sem qualquer necessidade, apenas como animais de estimação, foi proibido pelo Profeta." In: Yossef Al-Karadhawi, O Lícito e o Ilícito no Islam,
} 
apreciar o mar, na beira da praia, em duas linhas pictóricas. Na terceira, a câmera fixa capta, também na beira da praia, pessoas (na maioria, velhos) que caminham e às vezes param para conversar (por acaso, na frente da câmera, que parece escondida). Na quarta, um grupo de patos, na praia, vai e volta em frente à câmera.

Nestes quatro planos, as linhas horizontais predominam. No quinto plano, o único noturno, a câmera nos mostra a água de um brejo sendo refletido pela lua, ao som do coaxar de sapos (ou rãs) que anunciam a chuva. Fades acompanhados de música encerram os planos que, exceto talvez o último, são executados sem cortes. E exceto também o último, são seguramente locações naturais (a suspeita de que Kiarostami possa ter filmado a última parte em um tanque de água não deve ser descartada). Peças de vídeo-arte, boutades fílmicas de Godard e até mesmo o cinema comercial de Godfrey Reggio (Koyaanisqatsi, 1983, Powaqqatsi, 1988, Naqoyqatsi, 2002) podem ser evocados.

Como já referido aqui, cabe considerar o poder abstrato de Five como uma progressão de idéias, abstrações artísticas anteriores em torno da extensão do tempo, como, por exemplo, os 52 segundos que rodou para Lumière e Cia., onde um enredo inteiro é concentrado no tempo de um fritar de ovos. E como, principalmente, o longo plano do tubo de spray que rola em Close-up durante 55 segundos. Assim, a função do plano do spray, mais até do que pertencer ao universo dos objetos que rolam nos filmes de Kiarostami, e além de situar-se no reino dos jogos, a ser visto no capítulo 8, é resultado de uma experiência de distensão do tempo, onde o espectador é envolvido numa sensação de estiramento.

p. 186. Um dos hadiths também deixa clara esta interdição: "Anjos não entrarão em uma casa onde houver cães e imagens." (In: www.al-islam.com) 
Em relação a Five, se nos detivermos no primeiro plano-seqüência já temos material suficiente para uma longa investigação. O toco, ou o galho, pode ser uma variação-citação da árvore, imagem ícone de Kiarostami em Onde fica a Casa do Meu Amigo?, A Vida Continua, Através das Oliveiras e Gosto de Cereja (neste último, a árvore não aparece, mas é lembrada como o lugar onde o senhor Badii gostaria de ser enterrado). A árvore também disputa com os caminhos (trajetos, linhas, percursos) a onipresença nas fotos que Kiarostami assina e monta exposições. Youssef Ishaghpour interpreta a árvore como um ente cósmico "vínculo da terra com o céu, eixo do mundo nas antigas mitologias... agora a árvore talvez seja o que nos restou..."87.

Digamos que, então, o toco do primeiro plano de Five seja "a árvore" de Kiarostami. Mas afora seu significado metafórico possível, podemos inferir que o plano nasceu provavelmente na cena em que um osso é jogado no riacho no final de $O$ Vento nos Levará. Nele, a câmera acompanha a trajetória do osso levado pela correnteza.

Jean-Claude Bernardet, analisando os objetos em movimento nos filmes de Kiarostami, acredita que o osso represente a vida e a morte e "também o renovar da vida (foi extraído da terra, onde estava imóvel, para encontrar novo movimento no fim do filme)..." ${ }^{88}$ A idéia de morte neste primeiro plano é reforçada com o fade-out final, pois sabemos que Kiarostami considera que a "a vida vem da luz" $" 89$ (no final de Gosto

\footnotetext{
${ }^{87}$ Abbas KIAROSTAMI \& Youssef. ISHAGHPOUR, Abbas Kiarostami - Duas ou três coisas que sei de mim. O real, cara e coroa, op. cit., p. 89.

${ }^{88}$ Jean-Claude BERNARDET, Caminhos de Kiarostami, op. cit. p. 91.

${ }^{89}$ In: Michel CIMENT \& Stéphane GOUDET, "Entretian avec: Kiarostami: Um approche existencialiste de la vie", Positif, 442, p. 84.
} 
de Cereja Kiarostami deixa a tela escura por 1'30", sinalizando que o senhor Badii consumou o suicídio).

Ainda sobre o movimento de objetos, diríamos que seu afinco em trabalhar o movimento do osso na água remete ao rolar da maçã no mesmo $O$ vento nos levará e à lata de spray em Close-up, o que nos direciona a pensar que o galho-toco de Five não está ali porque está ali. Pode ter sido obsessivamente procurado e testado e que represente o mesmo que o osso: vestígio do que foi vida. Pode ter rachado, se divido em dois com a simples pressão da água, mas é plausível imaginar, a partir das manipulações anteriores, que Kiarostami tenha provocado esta ruptura do galho-toco através de uma leve pré-cisão voluntária.

Especulações à parte, a pergunta que fica quanto a este plano é: como pode haver suspense sem nenhum recurso de som, de luz, de voz, de montagem? Talvez porque estejamos paralisados frente a algo pouco (nada) usual. Esta experiência poderia muito bem pertencer a uma bienal de artes plásticas, onde propostas muito mais extremadas são expostas todos os anos. A diferença é que nestes espaços estamos circulando, alguém passa, alguém conversa, um guarda faz sua ronda. No cinema, se optamos por continuar vendo o filme, só nos resta contemplar a contemplação. E depois pensar.

\subsection{A natureza}


Five representa uma reiteração, de forma radical, no que diz respeito a relação de Kiarostami com a natureza. Sabemos de seu apreço estético e filosófico pelo tema, que leva freqüentemente a pautar diversas entrevistas mundo afora. Em entrevista em 1999 à revista Positif $^{90}$, por exemplo, fala de sua profunda atração por imagens da natureza, uma atração que ficou mais marcada em sua obra a partir de $O$ Vento nos Levará, em que exibe o colorido dos campos de trigo. Uma lembraça que trazia desde a infância, e que explora neste filme. Quando escreve, Kiarostami também reforça esta relação:

Essa é a única coisa que me faz temer a morte. Não o medo de morrer, mas a idéia de perder a natureza que ainda tenho, a possibilidade de contemplar o mundo. Porque o único amor que aumenta de intensidade a cada dia, enquanto os outros amores perdem sua força, é o amor pela natureza. É por esse motivo que meus próximos filmes ainda continuarão a observar a natureza, $e$ de fato seus temas constituirão um pretexto para encontrar-me de novo no meio dela. ${ }^{91}$

Diante da natureza, Kiarostami não se limita à contemplação. Ele parece querer interferir nela. Lembremos mais uma vez dos caminhos em ziguezague em Onde Fica a Casa do Meu Amigo? e Através das Oliveiras, do osso e da maçã em O Vento nos Levará, dos cinco planos de Five (exceto, talvez, o das pessoas caminhando) e do spray de Close-up. Suspender o tempo através de trajetos tortuosos e objetos que rolam não seria uma forma de interpor-se às leis da natureza?

Tanto em relação à natureza, quanto aos objetos que rolam, Kiarostami filia-se ao cineasta armênio Artavazd Pelechian, que trabalha com o documentário no registro do ensaio poético. Les saisons (Tarva yeghanakner, 1972), em especial, pois nele

\footnotetext{
90 "Abbas Kiarostami - Les yeux du coeur", Positif, 466,op. cit.

${ }^{91}$ Abbas KIAROSTAMI, “A arte da inadequação”, op. cit.
} 
prevalecem os planos onde rolam não só objetos, como as pessoas. Trata-se de um documentário, como Five, que não utiliza nenhum diálogo, e mostra o embate do homem com a natureza. Homens que rolam segurando ovelhas num mar revolto e em altíssimas montanhas de neve; homens que rolam montanha abaixo carregando rolos de feno. É de se supor que Kiarostami tenha visto os filmes de Pelechian, pois a Armênia faz fronteira com o Irã e durante o regime soviético as produções do gigantesco estúdio Armenfilm chegavam no país. ${ }^{92}$

O espectador da produção mais comercial do Ocidente, quando se depara com um objeto que rola em cena nos filmes de Kiarostami, pode pensar que está diante de um MacGuffin, recurso que Alfred Hitchcock transformou em marca registrada. Nele, o diretor desviava a atenção do principal para falar do nada. Já em termos de imagem poderíamos pensar em Roland Barthes e seu Punctum, que designa na imagem fotográfica "um nível de sentido não intencional". 93

Em Gilberto Perez, analisando especificamente o chute na lata de aerosol em Close-up, encontramos a idéia de que o gesto pode ser tomado como um "espirituoso epítome de aproximação naturalística" ${ }^{94}$. A lata pode estar ali, segundo ele, para representar o detalhe da rotina da vida no qual o naturalismo reside. Kiarostami estaria chamando a atenção para as formas do "realismo formal" que ele está empregando: a atenção para o detalhe, o desdobramento de causa e efeito. A ressonância da arte, conforme Perez, está nas mãos de Kiarostami, onde a lata de spray se torna expressiva e funciona como uma representação dos meios de representação. "É expressiva na

\footnotetext{
${ }^{92}$ Para mais informações ver o artigo "Na periferia do cinema", de Ivonete PINTO, in Teorema Crítica de Cinema, $\mathrm{n}^{\circ} 1, \mathrm{p} .32-35$.

${ }^{93}$ In: Jacques AUMONT e Michel MARIE, Dicionário Teórico e Crítico de Cinema, p. 248.

${ }^{94}$ In: Gilberto PEREZ, op. cit, p. 263.
} 
maneira característica do modernismo. $\mathrm{O}$ detalhe do naturalismo é tratado como autoconsciência do modernismo e transformado em metáfora para os meios da arte"95.

Mas é quando fala em rotina da vida, que Perez, sem querer, nos permite trazer uma afinidade eletiva que uniria criador e criatura: Kiarostami e Ozu.

Além do minimalismo narrativo característico dos dois diretores, como Kiarostami, Ozu não gostava de revelar suas verdadeiras intenções, preferia trair as expectativas do espectador ${ }^{96}$, e operava com o conceito de repetição. De acordo com Kiju Yoshida, em $O$ Anticinema de Yasugiro Ozu, a repetição (e defasagem) pode ser interpretada como chave do universo cinematográfico do diretor.

Para resistir à tirania do presente que progride continuamente no vazio sem que possa ser detido, suspendemos o fluxo do tempo quando insistimos em repetições, e dessa maneira representamos o presente que vai mudando a cada segundo como uma volumosa pilha de acontecimentos, a que chamamos passado. ${ }^{97}$

Embora o que seja repetido em Ozu sejam perfis de personagens (o pai) e situações (casamentos), é aceitável que comparemos as repetições em Kiarostami às dele, pois que o que se repete no iraniano tem estatuto dramático, tem função narrativa. Mais do que isto, são peças reiterativas quando nosso olhar sobre Kiarostami recai na questão da natureza.

\footnotetext{
${ }^{95}$ Idem, p. 264.

${ }^{96}$ Um dos exemplos de traição de expectativa é, em Close-up, no corte no áudio, onde Kiarostami não realiza nossa expectativa em relação ao diálogo de Sabzian com Makhmalbaf. E, em outro exemplo, quando deixa a câmera do lado de fora da casa onde os policiais vão prender Sabzian. Em Ozu, conforme Kiju YOSHIDA em O Anticinema de Yasugiro Ozu, o diretor abrevia a cena do casamento, tema central do filme $A$ Rotina tem seu encanto.

${ }^{97}$ In: Kiju YOSHIDA, p. 273-274.
} 
Estes exemplos de repetição, de objetos que se movem, onde o significado do vento também não pode ser esquecido ${ }^{98}$, nos permitem deduzir que Kiarostami nunca está satisfeito com sua condição humana de impotência frente ao andar irrefreável dos acontecimentos da natureza. Kiarostami quer brincar de ser Deus, exercendo seu poder de ingerência, enquanto gerador de imagens, nos desígnios dessa natureza. E como na cena do julgamento, Kiarostami o faz com um certo abuso. Mas, afinal, a graça do poder não estaria no abuso?

98 Neste sentido, ver Jean-Claude BERNARDET, Caminhos de Kiarostami, op cit., que desenvolve análise sobre o vento. Acrescentamos também que Kiarostami provavelmente começou a pensar sobre o vento, afora todo o estímulo encontrado na poesia persa pré-islâmica, como a de Kayyam, a partir do filme praticamente sem diálogos do iraniano Amir Naderi, Água, Vento e Areia (Aab, baad, khaak, 1989). Nele, durante os 75 minutos de projeção, ouvimos sem interrupção o som do vento. 


\section{7 - O julgamento}

A farsa do tribunal; o juiz que não estava lá; o comprometimento da verossimilhança; Kiarostami como juiz.

Se é difícil encontrar a verdade, Guy Gauthier, em Le Documentaire, un Autre Cinema, recomenda que ao menos nos perguntemos se os vestígios e testemunhos são autênticos ou reconstituídos. A maior parte de Close-up foi reconstituída. São acontecimentos do passado (considerando "passado" como o tempo anterior à entrada de Kiarostami nos fatos), encenados e mostrados em flashbacks. O filme todo se articula em flashback, que por si só é um dispositivo falso, uma armadilha no entender de Genette $^{99}$, mas aqui ele opera para exibir a ficção, arena onde tudo é legítimo.

Então, levando em conta que este arcabouço do passado foi engendrado, nos voltemos às seqüências do filme com estrato documental, pois que acontecem no tempo presente e, supostamente, não foram roteirizadas nem encenadas, muito embora a montagem de Kiarostami nos leve para outros caminhos. Estas seqüências encerram uma peça-chave do filme, o julgamento.

A cena do julgamento inicia diferente das outras do filme: uma claquete indica o número do take e da cena. Paradoxalmente, este que seria o momento documental mais puro do filme, na verdade nos introduz no espetáculo cinematográfico, no evento que inclusive foi remarcado em função da agenda de Kiarostami. A claquete informa a data

\footnotetext{
${ }^{99}$ Genette usa o termo "analepses" (do grego, ação de retomar), in: Figures III, op. cit.
} 
"10 de dezembro", sendo que na cena anterior, Kiarostami solicitava ao Hadj ${ }^{100}$ que o julgamento fosse antecipado, pois que não poderia filmar no dia marcado, 19 de dezembro. Kiarostami, assim, demonstra seu poder ao exibir a data do dia 10 na claquete.

No livro Abbas Kiarostami, Alberto Elena revela como o diretor filmou as cenas do tribunal e como a montagem construiu o julgamento que se vê na tela. Após a sessão, a equipe obteve permissão do juiz Hadj Ali Reza Ahmadi - ao mesmo tempo um mulá e um hadj - para continuar na sala “entrevistando" Sabzian. É pertinente supor que esta permissão deveu-se ao fato de se tratar de um crime menor, sendo que o mérito do processo diz respeito à falsa identidade e a uma soma pequena (1.900 tomans ${ }^{101}$, o suficiente para tomar um táxi de longa distância), dinheiro que o falso Makhmalbaf tomou de empréstimo da família Ahankhah.

Neste ponto o "documento" ganha maiores contornos de simulação. Simulação no sentido de "imitação do funcionamento de um processo por meio do funcionamento de outro". ${ }^{102}$ É o momento em que o diretor faz perguntas ao réu, incluindo na montagem os inserts do juiz, como se ele, Kiarostami, estivesse interrogando Sabzian em pleno ritual do julgamento, e o juiz simplesmente assistisse ao cineasta fazer o papel de juiz. “A sessão durou uma hora, mas logo nos despedimos do juiz e seguimos conversando com o acusado, a portas fechadas, durante outras nove horas. Portanto, reconstruímos uma grande parte do julgamento na ausência do juiz, o que constitui uma

\footnotetext{
${ }^{100}$ Hadj é o nome dado à peregrinação realizada à cidade santa de Meca pelos muçulmanos e serve como uma espécie de título a quem a fez na época mais apropriada, que é o Ramadã.. Equivale ao último dos cinco pilares do islã, sendo obrigatória pelo menos uma vez na vida para todo o muçulmano adulto. Aproximadamente 2 milhões de pessoas fazem anualmente a peregrinação.

${ }^{101}$ O Rial é a moeda oficial no Irã e o "toman", citado no filme, é o Rial diminuído de 3 zeros, que foi criado para facilitar as contas, o comércio.
} 
das maiores mentiras que jamais me permiti”, confessa o diretor. ${ }^{103}$ Note-se que é o próprio diretor quem traz o termo "mentira".

\subsection{Trapaça}

Kiarostami, com isto, se permitiu (buscou) um grau de interferência tal que, graças à inserção de planos fechados do juiz, o público passa a acreditar que as perguntas que ele fez a Sabzian estavam dentro do rito ordinário da sessão de julgamento, na presença do juiz (!). Uma trapaça que o diretor, mesmo que pareça envergonhado, admite. Ao contrário da cena mais emblemática para esta análise, que mostra a "falha do som", onde Kiarostami dissimula mesmo depois de descoberto.

Ainda sobre as seqüências do julgamento, uma leitura mais atenta colocaria em dúvida a possibilidade de interferência tão desmedida de Kiarostami. Se prestarmos atenção, veremos que há um momento em que a mãe de Sabzian fala alguma coisa em defesa do filho e rispidamente é interrompida pelo juiz para que se cale, numa clara demonstração de que neste tipo de rito não são toleradas intervenções. Mesmo o público estrangeiro, sem conhecer os trâmites de um tribunal islâmico inserido no sistema da sharia, poderia desconfiar que não bastaria ser um cineasta respeitado para deflagrar tal permissividade no rito. No Irã pós-revolução, um juiz deve ser um religioso (mulá) ${ }^{104}$, mas mesmo que o país não pertença ao Common $\operatorname{Law}^{105}$, existe uma liturgia de

\footnotetext{
${ }^{102}$ Definição lexical in: Dicionário Eletrônico Houaiss da Língua Portuguesa.

${ }^{103}$ Stéphane GOUDET, Positif, ${ }^{\circ}{ }^{4} 42$, op. cit., p. 95.

${ }^{104}$ Cf. Aidah RUMI, Os Princípios Islâmicos, p. 120.

${ }^{105}$ O Irã foi dominado por russos e ingleses durante a dinastia Qajar (séc. XIX e XX), tendo sofrido influência britânica desde aquele período, que persiste na dinastia Pahlevi e vem até os dias atuais.Nos países anglo-saxões, em que predomina o Common Law, aí incluídos aqueles colonizados pelos ingleses,
} 
tribunal, onde o público não pode se manifestar e as testemunhas não podem falar antes do juiz chamá-las. Lá, o juiz, como no sistema do Common Law, decide se pode ou não ter fotógrafos na sala. No caso, foi necessária a autorização especial ao departamento de justiça. De todo modo, a liturgia não permitiria tal intervenção, como se o cineasta estivesse conduzindo a sessão, como se tivesse ocupado o lugar do juiz.

Nesta medida, Kiarostami embaraça o princípio da "corte aberta", blefa e compromete a verossimilhança. No entanto, o objetivo do diretor é alcançado graças a este estratagema, pois na ausência do juiz, Kiarostami conseguiu aproximar-se mais de Sabzian, no sentido polissêmico do título do filme, e com isso ofereceu uma chance ao réu de mostrar sua faceta mais humana, mais inocente. E, além disto, conseguiu que Sabzian discorresse sobre o que de fato interessava a ele, Kiarostami: o conteúdo cinefílico de todo episódio.

Assim, é depois do julgamento que Sabzian, tendo Kiarostami como “juiz", elabora seu raciocínio mais sofisticado ao responder à pergunta do diretor: ("Você está atuando para a câmera agora?") - "Não, estou falando do meu sofrimento, isto não é atuar, é do coração". E cita Tolstói: “Arte é uma experiência sentimental que o artista divide com os outros". Sabzian encerra a citação com a frase: "Eu creio que esta é uma experiência que eu quero compartilhar com os outros".

Evidenciando sua ligação com o cinema, Sabzain fala dos filmes que influenciaram sua conduta. Diz que é como a criança de $O$ viajante (Mossafer, 1974), dirigido por Kiarostami, que finge tirar fotos das pessoas (a câmera não tem filme) para 
conseguir dinheiro e poder assistir a uma partida de futebol. ${ }^{106} \mathrm{O}$ menino acaba não vendo o jogo porque adormece de cansaço. "Sinto-me como se também tivesse perdido o jogo", filosofa o impostor.

Mas como num conto de fadas, nem Sabzian nem a família Ahankhah perderam o jogo, pois passaram a pertencer ao mundo do cinema. Tiveram suas imagens eternizadas em película e, portanto, passaram a ter direito a uma existência, a uma imagem qualificada pelo outro. Existem. O preço a pagar vem na forma do constrangimento: especialmente quando a câmera focaliza o filho mais velho dos Ahankhah, Mehrdad, há uma vergonha em seu rosto, um sofrimento por estar ali admitindo que foi enganado por alguém como Sabzian, que sequer estudou como ele (Mehrdad é formado em Engenharia). Um sofrimento que podemos relacionar com a encenação de Karbala, pois Mehrdad "açoita-se” simbolicamente, em público, em nome do projeto maior, que é participar de um filme de verdade, o de Kiarostami, e não um de mentira, o de Sabzian.

A postura de Kiarostami ao incluir takes do juiz durante a entrevista/interrogratório realizada pelo diretor, nos leva a retomar e ratificar nossos alvos de análise. Chamamos a atenção, neste sentido, para o cuidado que se teve aqui no uso o termo artifício, que aparece quando a situação envolve a operação cinema (narrativa, linguagem, estética). Quando não se questiona a liberdade do diretor de “cenarizar” a imagem num filme de ficção, mesmo que de caráter realista, optamos pelo

106 Esta frase de Sabzian é a resposta negativa que Kiarostami dá ao seu interlocutor em um documentário, quando este salienta que Close-up, ao contrário de outros filmes do diretor, não tem crianças. Kiarostami, além de lembrar ao entrevistador a referência a $O$ Viajante, cita outros filmes com crianças, como Lição de Casa (Mashq-e Shab, 1989) e Onde Fica a Casa do Meu Amigo. O diretor, com isto, deixa claro que coloca Sabzian no mesmo patamar, ou seja, considera-o uma criança como as outras 
termo artifício. A nosso ver, é claramente um artifício em nome do realismo a cenarização, por exemplo, no filme $O$ Vento nos Levará. A vila Siah Dareh, situada no curdistão iraniano, foi remodelada para a produção (limpa, pintada), onde a própria personagem dona da casa de chá não pertencia aquela vila. O filme não deixou de ser realista, pois aquela senhora poderia ser daquele local (ela habitava próximo dali) e muitas vilas no Irã são limpas e têm as casas coloridas. Uma intervenção em nome do realismo. Situação totalmente diferente ocorre com os inserts do juiz, quando nos permitimos usar o termo mentira, pois o juiz não poderia ter simplesmente assistido Kiarostami interrogar Sabzian durante o julgamento. Ou seja, o problema nesta cena é maior do que a quebra da verossimilhança, é uma quebra da verdade, do real.

de seus filmes. In: Documentário Friendly Persuasion: Iranian Cinema After The Revolution, de Jamsheed Akrami. 


\section{8 - O som que engana}

Como Kiarostami manipula o som para parecer espontâneo, verdadeiro e ao mesmo tempo esconder uma informação que não lhe interessa; o acaso; a taqiya; as dissimulações e as simulações em Kiarostami.

Examinando com atenção os primeiros filmes de Kiarostami, observamos que o diretor inicia sua descoberta das possibilidades do som, como narrativa, com o curta $O$ Coro (Hamsorayan, 1982). Um idoso percorre as ruas barulhentas da cidade usando um aparelho de surdez. Faz compras, conversa com pessoas. A cidade é muito barulhenta. Chega em casa, no segundo andar de um prédio, e um ruído de máquina vindo da rua o perturba. Retira o aparelho e começa a comer os rabanetes que comprou. Vemos que crianças chamam por ele, mas ele não ouve. Não há mais som algum quando a câmera está com ele. Quando a câmera vai para a rua acompanhar as crianças, o som volta. São meninas, suas netas, que gritam para que ele abra a porta. Tocam a campainha e nada. Ele continua sem ouvir. Ele olha para o relógio, parece esperar por elas. Quando o volume é muito alto, pois já uma pequena multidão de crianças grita por ele em frente à casa, ele se dá conta, recoloca o aparelho e acaba o filme. Sem um grande enredo, na verdade é uma experiência com o som, muito antes de Makhmalbaf ter feito O Silêncio (Sokhout, 1998) e oito anos antes de Close-up.

Close-up apresenta-se como uma peça desafiadora para estudiosos do cinema. “A natureza translúcida de fato-como-fantasia transforma a lente diáfana pela qual 
Kiarostami começa a nos mostrar jeitos de olhar o que nós não sabíamos que existia.”, tenta explicar Hamid Dabashi ${ }^{107}$.

Quando a linha de raciocínio nos leva para a verdade que o diretor expõe através da aproximação da lente no rosto do protagonista, surge um elemento novo na narrativa. Elemento este encontrado no som e que derruba as assertivas imagéticas que poderiam haver ainda sobre a autenticidade de todos os fatos mostrados.

Mesmo que em Close-up exista uma supremacia do texto e que o som ambiente natural seja respeitado, pode-se afirmar que o ritmo de todo o filme é marcado pelos silêncios. Como o espectador está acostumado com o excessivo volume do som nas salas de cinema, quase a uma esquizofrenia de ruídos, filmes como este de Kiarostami são acusados de exibir um ritmo excessivamente lento, quando não um "ritmo parado". Dessa forma, uma eventual não-comunicabilidade do filme pode ser atribuída ao uso do som através do silêncio. Um silêncio que narra, mas que ao mesmo tempo provoca estranheza. Estranheza, talvez, porque como afirma Foucault, a sociedade renunciou ao silêncio. De acordo com Foucault, ensinava-se aos jovens romanos e aos gregos a adotarem diversos modos de silêncio, dependendo com quem se encontrassem. "O silêncio é, penso, algo que merece ser cultivado. Sou favorável que se desenvolva esse êthos do silêncio." 108

\footnotetext{
${ }^{107}$ In: Hamid DABASHI, Close Up Iranian Cinema, p. 67

${ }^{108}$ Stephen RIGGINS , "Silêncio, sexo e verdade - Uma entrevista com Michel Foucault". Toronto, 22 de jun de 1982. Traduzido a partir de Michel FOUCAULT, Dits et Écrits. Paris: Gallimard, 1994, Vol. IV, pp. 525-538, por Wanderson Flor do Nascimento. http://www.unb.br/fe/tef/filoesco/foucault/silence.html
} 
A ausência de diálogos entendida como silêncio é um elemento importante na estrutura minimalista e de grande sobriedade formal praticada por Kiarostami em todos seus filmes. Ele cita, inclusive, Milan Kundera para reforçar esta predileção. Em entrevista à Positif, Kiarostami lembra que o pai de Kundera, no fim de sua vida, não usava mais do que duas palavras em seu vocabulário: “é estranho". "E ele repetia estas duas palavras sem cessar, não porque não tivesse mais nada a dizer, mas porque elas resumiam o melhor de sua experiência na vida."109

No entanto, nos filmes de Kiarostami, quando vemos personagens dialogando, mas o som das palavras nos escapa, nossa atenção deve ser redobrada, como podemos ver a seguir.

Na seqüência em que o falso Makhmalbaf encontra na saída da prisão o verdadeiro Makhmalbaf, Kiarostami opera quatro camadas de percepção.

Na primeira camada, temos o som intenso da rua, com carros, buzinas e vozes a fazer a algaravia do trânsito da cidade gigante que é Teerã (14 milhões de habitantes). Nesta mesma camada, Kiarostami enriquece a narrativa ao enfatizar o clima de tensão na cena em que temos o ponto de vista de Sabzian para o momento de sua prisão (os policiais chegam na casa dos Ahankhah e este não sabe o que está acontecendo). Kiarostami colocou neste momento o som de uma gralha (ou um pássaro com grasnar semelhante, que faz lembrar Os Pássaros, de Hitchcock). Sabzian está sozinho na sala. Da cozinha percebemos ruídos de louças e, depois do pássaro que grita, ouvimos cães latindo. Conscientemente, o espectador apenas vê/ouve o silêncio de Sabzian. Por não

\footnotetext{
${ }^{109}$ In: "Entretian: Abbas Kiarostami - Des femmes réelles et non de cinema". Entrevista a Michel CIMENT e Stéphane GOUDET, Positif, nº 499, p.17.
} 
haver diálogos, a cena é percebida como um momento de ausência de som. Mas, como diz Walter Murch, silêncio também é som ${ }^{110}$.

Na segunda camada, temos o diálogo espasmódico entre Sabzian e Makhmalbaf. Na terceira, os ruídos mecânicos que entrecortam este diálogo e que fazem o espectador projetar-se para fora da história, lembrado pelo diretor de que o desenrolar dos fatos está sendo mediado pelo cinema.

Por fim, na quarta camada, há o diálogo de Kiarostami com a equipe técnica do filme, a nos introduzir uma outra ficção/invenção no que já era uma encenação nos termos aristotélicos da Poética.

Seguramente, este momento teleológico, quando Makhmalbaf encontra Sabzian na saída da prisão e o som da voz dos dois começa a falhar, é a cena mais simbólica do filme quanto ao uso do som e quanto à capacidade/habilidade de Kiarostami de iludir a platéia.

A cena, que dura 4'44", inicia já com o diálogo da equipe dentro de um carro. Está sendo utilizada uma câmera escondida para registrar o encontro e o técnico de som comenta com Kiarostami que o microfone está falhando. Os diálogos indicam que o diretor opta por não interromper a filmagem.

A transcrição dos diálogos é a seguinte:

\footnotetext{
110 "Silêncio também é som e às vezes é uma benção." In: Roy Paul MADSEN, Working Cinema Learning from the Masters, p. 311
} 
Kiarostami (de dentro do carro da equipe) - Eu não estou vendo Makhmalbaf.

Técnico 1- Não conseguimos mais captá-lo.

Kiarostami - Eu o vi, ele está atrás daquele táxi.

Técnico 1- Eu o vi.

Kiarostami - Está bem.

Técnico 2- O som foi cortado.

Kiarostami-O quê?

Técnico 2 - O som foi cortado!

Kiarostami-Mas o que houve?

Técnico 2 - Pode ser o plugue ou o microfone no pescoço de Makhmalbaf. O equipamento é velho. Faz anos que nós o usamos. Tem um fio solto em algum lugar.

(Pausa)

Kiarostami - Teremos esse problema até o fim?

Técnico 2 - Não há como evitar.

(Diálogos entrecortados entre Makhmalbaf e Sabzian):

Makhmalbaf-É o senhor Sabzian?

Sabzian - Sim, muito prazer...

Makhmalbaf - Não chore. Não faça assim. Diga-me, quando é que você foi solto?

(Ruidos, falha do som)

Sabzian - Eu queria ver o senhor Ahankhah.

Makhmalbaf - Ok, eu levo você lá.

(Falha do som)

Makhmalbaf - Você já havia me visto?

Sabzian - Sim, no filme Feridas de um Casamento. 


\section{(Falha do som)}

Makhmalbaf - O que é melhor, ser Makhmalbaf ou ser Sabzian? Eu estou cansado de ser Makhmalbaf.

Seguem mais diálogos entrecortados. Makhmalbaf dá carona para Sabzian em sua moto, seguida pela equipe de filmagem. Pela primeira vez no filme, entra trilha musical. Aliás, a inclusão da música no final, quando Sabzian sobe na moto de Makhmalbaf para ir à casa dos Ahankhah, parece-nos uma proposta de distanciamento que Kiarostami faz ao espectador. Sabemos que a ausência de música tem uma função muito clara na desdramatização, em consonância com a representação da "vida real". Afinal, quando sofremos de algum mal, quando recebemos uma má notícia, quando vemos algo fora do comum, não costuma entrar uma música de fundo. Por isso, na cena de Sabzian com Makhmalbaf a música causa um choque, pois parece contradizer a “intenção de realidade”. Mas ao mesmo tempo é um acordar, é Kiarostami chamando a atenção para o fato de que, mesmo tendo construído a narrativa para dar a impressão de realidade, o filme é a versão dele para os fatos. Assim, esta entrada da música pode ser percebida como contradição interna principalmente relacionada com a cena que veio anteriormente (o corte do som), mas também como advertência de que, embora tudo pareça real, trata-se de uma construção não desprovida de artifício.

Depois do "acidente" com o som, a equipe não volta mais a falar. No último plano do filme, em frente à casa dos Ahankhah, a câmera sai do plano aberto e posiciona-se ao lado de Sabzian, fechando em close. 
A expectativa fica em suspenso, pois não sabemos se o senhor Ahankhah perdoou Sabzian, nem mesmo se Makhmalbaf o fez. O famoso diretor iraniano, idolatrado pelo pobre Sabzian, teve seu diálogo cortado durante o encontro, numa aleivosia do diretor?

\subsection{Acaso}

Este aproveitamento dramático de um "acidente" nos leva a pensar na noção de acaso trabalhada por Noël Burch. Se, como diz Burch, o acaso funciona como um intruso em relação à música, no cinema ele esteve "sempre em casa, pois os cineastas tiveram que aceitá-lo, de qualquer jeito, desde o início" ${ }^{111}$. No entanto, os cineastas sempre lutaram contra o acaso, defendendo o que estava planejado para constar ou não de determinado enquadramento. Graças ao desenvolvimento técnico, o acaso tornou-se cada vez mais controlado, sendo que a imprevisibilidade do mundo sempre pode contar com o refúgio dos estúdios, mais ou menos à prova de acasos. Por questões de estilo, o acaso ganha espaço, lembra Burch, em cineastas como Vertov, e mais adiante Jean-Luc Godard e Jean Rouch, que o experimentaram em suas propostas de sintaxe cinematográfica.

Kiarostami não estaria, desse modo, inventando a roda. A nuance complicadora - e perturbadora - no caso de Close-up diz respeito ao fato de ser um acaso forjado. $\mathrm{O}$ espectador não se dá conta, e só mesmo um exame apurado poderá detectar o que está acontecendo ali.

${ }^{111}$ In: Noël BURCH, Práxis do Cinema, p. 135. 
À primeira vista, não duvidamos que o microfone esteja falhando, porém chama a atenção que a voz, quando volta, é limpa, não há picos de altura de som e este "padrão" permanece mesmo quando Kiarostami coloca inserts no meio de um plano. Por outro lado, não se trata de equipamento velho, como argumenta a equipe no carro. A captação do som tem qualidade, principalmente considerando que é feita por um microfone de lapela, sem fio (não teria como ser um "boom", pois o enquadramento é muito aberto).

As entradas e saídas de som são limpas, sem interferências/arranhões, o que é estranho já que o som não costuma desaparecer sem falhas. Outro detalhe: como a produção é de 1989-1990, de baixo orçamento, é improvável que Kiarostami tenha usado dois gravadores (um para gravar o som de dentro do carro, outro para captar o diálogo de fora) e é improvável também que tenha contado com um gravador estereofônico, que daria conta da captação em dois pontos. Para produções de baixo orçamento, o comum nesta época era o uso do gravador analógico. Portanto, a captação das vozes no carro, simultaneamente ao som do diálogo externo, estaria inviabilizada. De onde se depreende que todos os diálogos dos técnicos com Kiarostami foram construídos, em estúdio, após a filmagem. ${ }^{112}$

A hipótese é corroborada pela seguite seqüência: durante o encontro de Sabzian com Makhmalbaf o som falha e permanece falho durante o trajeto dos dois, na moto de Makhmalbaf até a casa dos Ahankhah. Quando chegam na casa, o som volta absolutamente normal. Por que a voz da equipe não entrou em off novamente para

\footnotetext{
${ }^{112}$ Informação oral: Conforme o profesor de Sound Design do curso de cinema da USP, Eduardo Santos Mendes, analisando tecnicamente o uso do gravador nesta cena.
} 
comentar que o som voltou? Como é possível que o microfone tenha voltado a funcionar sozinho?

Sob a perspectiva do documental, é como se Kiarostami se dirigisse ao espectador, como se "interpelasse" o espectador, na expressão que Roger Odin usou para investigar Lettres d'amour en Somalie. Odin refere-se à tentativa de estabelecer entre o filme e o espectador uma distância que evita a mobilização de defesas. "Isto que caracteriza o documentário, por oposição ao filme de ficção, é, sabemos, que ele interpela o espectador como pessoa real..."113

Contudo, não é indicado que nos deixemos seduzir pela idéia de que Kiarostami está fazendo documentário nesta cena. A "pessoa real” que assiste a Close-up está na verdade submetida a uma (outra) farsa, quando Kiarostami promove o fake dentro do fake, exercendo todas as prerrogativas do cinema como invenção. É o fakery, na definição de Brian Winston em Lies, Damm Lies and Documentaries. Winston não suaviza as palavras, definindo os documentaristas que criam situações nascidas na imaginação vendendo-as como realidade, como mentirosos. E mais: "Eles são para a produção da mídia o que os pedófilos são para a creche."114

Em entrevista a Hormuz Kéy, o diretor confessa a artimanha: "Sim, foi voluntário, eu fiz aquilo tudo conscientemente..."115. Avisa que não há regras a serem seguidas em cinema. Diz também que Makhmalbaf portava um microfone de lapela e Sabzian, que desconhecia a filmagem até aquele momento, tinha sua voz captada pelo microfone de Makhmalbaf. Kiarostami alega que não quis expor o julgamento de

\footnotetext{
${ }^{113}$ In: Roger ODIN, De la Ficcion, p. 149.

${ }^{114}$ In: Brian WINSTON, Lies, Damm Lies and Documentaries, p. 10.
} 
Makhmalbaf em relação a Sabzian. Preferiu que os espectadores preenchessem, a sua maneira, os espaços falhos do som, mesmo contrariados (iranianos contam que em algumas sessões, no Irã, o público assobiava, vaiava a deficiência técnica que o impedia de ouvir claramente o diálogo). Kiarostami defendeu ainda que seria um assunto privado entre um fã e seu ídolo. Ele não teria se sentido no direito de tornar público aquele diálogo, até em respeito a Sabzian, que ignorava estar sendo filmado, e o deixava (mais) fragilizado em relação a Makhmalbaf.

O diretor voltou a falar sobre a cena revelando mais detalhes, como o fato de que o montador se recusou a fazer os cortes bruscos na banda sonora como ele queria, obrigando o próprio diretor a assumir a moviola ${ }^{116}$ (nos créditos é Kiarostami quem aparece como montador). Em entrevista à revista iraniana Film International, Kiarostami diz que o técnico de som, Ahmad Asgari, teve problemas, que algumas pessoas disseram que ele havia arruinado a reputação deste técnico, que nunca mais conseguiria trabalho depois de todas aquelas interrupções no som. ${ }^{117}$

E o que parecia suficientemente embaralhado fica mais grave ao sabermos, através de Makhmalbaf ${ }^{118}$, que no diálogo suprimido Sabzian dizia que não queria fazer o filme (esta seqüência final foi a segunda do filme a ser rodada) ${ }^{119}$. Portanto, há a versão de Kiarostami e a versão de Makhmalbaf. Quem está dizendo a verdade? Por que Kiarostami dissimulou até em entrevistas?

\footnotetext{
${ }^{115}$ In: Hormuz KÉY, op. cit., p. 168.

${ }^{116}$ In: Stéphane GOUDET, Positif n ${ }^{\circ} 442$, op. cit.

${ }^{117}$ Film International. "Debates with Kiarostami, Iranian movie director",op. cit.

${ }^{118}$ Idem, p. 127.

${ }^{119}$ Para outro autor, Kiarostami conta que Sabzian chegou a procurar o juiz para prestar queixa contra ele.

O juiz o convenceu de que o filme seria um bem para ele, Sabzian. In: Hormuz KÉY, op cit, 162.
} 
Esta cena e sua repercussão nos leva a concluir que Kiarostami "fala por paradoxos" 120 , ao "proteger" Sabzian porque este não sabia que estava sendo filmado (Makhmalbaf sabia) e, ao mesmo tempo, ao eliminar a possibilidade de Sabzian expressar suas dúvidas quanto ao próprio filme.

\subsection{Taqiya}

O crítico e pesquisador espanhol Alberto Elena chegou a afirmar, no livro dedicado ao cineasta, que Kiarostami cultiva a taqiya, que consiste na prática muçulmana da dissimulação, do ocultamento.

A taqiya era uma artimanha utilizada nos primeiros séculos do islamismo pelos xiitas, principalmente a seita dos ismaelitas, que visava ocultar a condição muçulmana para fugir às perseguições de cunho religioso. O recurso fazia sentido em países onde a população muçulmana xiita era minoria, e não era o caso do Irã, onde este grupo historicamente sempre foi maioria.

Para iluminar este aspecto do ocultamento em Kiarostami, dentro do contexto religioso xiita, somos mais inclinados a fazer outra associação, a com o Imã Oculto, o $12^{\circ}$ Imã que um dia irá voltar. Muitos iranianos, incluindo o aiatolá Khomeini, são adeptos de uma corrente que acredita que o $12^{\circ}$ imã, Mahdi, reaparecerá como um messias, para restaurar o verdadeiro islamismo (trata-se do grupo chamado Dozeno do

\footnotetext{
120 "Falar por paradoxos" é expressão tomada de Hannah Arendt quando trata da Revolução Francesa, citando a frase de Robespierre para definir o seu governo como o "despotismo da liberdade". Hannah ARENDT. Da Revolução, 1988.
} 
Xiismo $\left.^{121}\right)$. O que está oculto, escondido, é algo tão real e pragmático ao universo iraniano que a própria Constituição, criada com a Revolução de 1979, assegura que o Imã Oculto um dia voltará.

Se nos desprendermos do vínculo religioso, podemos pensar que Kiarostami segue a tradição de uma técnica de escritura particular que consiste em escrever "nas entrelinhas”. Esta técnica já era encontrada na produção filosófica da Idade Média onde os escritores, em especial judeus e árabes, cultivavam uma arte secreta de escrever, de tal modo que um pensamento livre pudesse "dedicar-se à pesquisa da verdade sem ferir abertamente a opinião, logo, evitar ser ferido, protegendo-se da perseguição" ${ }^{122}$.

Se esta vinculação ainda soa distante, podemos gerar a hipótese de que a predileção de Kiarostami pelo ocultamento, pelo não-dizer, deve-se mais à influência da poesia mística sufi ${ }^{123}$, repleta de códigos, de subtextos, de não-linearidades, que influenciam um modo de pensar a arte e, por extensão, o cinema iraniano. Um dos maiores poetas persas sufis, Rûmî (1207-1273), falava de "uma verdade sem forma" e lançava pensamentos como: "É o desejo do verdadeiro que faz com que os homens comprem o falso." 124

\footnotetext{
${ }^{121}$ Para mais detalhes ver Le Recit de L'Eveil - Retrospectif sur l avie idéologique-scientifique et politique de L'Iman Khomeiny - De la naissance Jusqu'au Décès, de Hamid ANSAR. Teheran: L'Institut de La Rédaction et de la Publication des Ouvres de L'Iman Khomeiny, 1996.

${ }^{122}$ In: Suzana Guerra ALBORNOZ, Trabalho e utopia na modernidade. A autora faz a citação a partir do livro "L'utopie de Thomas More à Walter Benjamin", de Miguel Abensour. http://www.unisc.br/cursos/graduacao/filosofia/docs/trabaho_utopia.pdf

${ }^{123}$ O Sufismo é o aspecto místico e esotérico do islamismo, que pode estar associado tanto ao islã sunita, como ao xiita. A influência desta corrente em Kiarostami, entre outros momentos, pode ser vista no título do filme Onde está a Casa do meu Amigo?, tirado do poema "Direção" do poeta sufi Sohrab Sepehri, como destacou Alberto ELENA, op. cit.

${ }^{124}$ In: Jalalud-din RÛMÎ, El Masnavi, p. 120.
} 
Mohsen Makhmalbaf, num filme produzido um ano depois do de Kiarostami, Tempo de Amor (Nobat-e Asheghi, 1990), cita um aforisma de Rûmî, lançando luz no fim do túnel: A verdade era um espelho que caiu e se quebrou. Cada um apanhou um pedaço e, vendo refletida nele sua própria imagem, acreditou estar de posse de toda a verdade.

No intuito, ainda, de lançar hipóteses originais para desvendar Close-up, poderse-ia cair na tentação de dizer, simplesmente, que Kiarostami "joga sujo": omite o diálogo de Sabzian com Makhmalbaf, fazendo crer, por entrevistas, que respeitava a intimidade dos dois, quando, de fato, pretendeu esconder as desconfianças de Sabzian sobre o próprio Kiarostami.

A estratégia do ocultamento, que se inicia na cena do spray (onde Kiarostami não nos mostra Sabzian), e a cena da falha do som, revelam um exercício do não-dito. Kiarostami subtrai, porque, segundo ele, mostrar é pornográfico. Não subtrai por tirania, mas para provocar. Ou, quem sabe, para demonstrar poder. Por trás da humildade estaria o uso do poder. Sua versão para o não-mostrar está mais aprofundadamente nesta entrevista:

Em minha perspectiva, a abstração que aceitamos nas outras formas artísticas - pintura, escultura, música, poesia - também pode entrar no cinema. Em persa, temos um ditado que afirma, quando alguém olha algo com verdadeira intensidade: "Tinha dois olhos e pediu mais dois emprestados". Estes dois olhos tomados de empréstimo são aquilo que quero capturar. É o desejo de lutar contra tudo o que os filmes de entretenimento fazem diariamente: pretender mostrar tudo ao público, a ponto de tornarem-se pornográficos. Não digo sexualmente pornográficos, mas no sentido de mostrar uma operação cirúrgica sem véus, em todos os seus detalhes repugnantes. Sinto que cada vez que um espectador tem o impulso de virar a cabeça ou olhar para o outro lado é porque essas cenas não são necessárias na tela. Ao contrário, minha maneira de enquadrar a 
ação obriga os espectadores a manterem-se mais direitos e a esticar o pescoço para tentar enxergar aquilo que eu não mostro! $!^{125}$

Em oportunidade anterior, respondendo a uma pergunta de Mehrnaz Saeed-Vafa sobre seus "princípios de elipses e omissão", Kiarostami vincula a estes princípios a idéia de documentário. Ele afirma que poderia fazer seus filmes melhor dependendo menos de sua experiência pessoal e pensando mais no filme como um meio de documentação, "onde o público poderia colocar as peças juntas, a sua maneira" ${ }^{126}$. Ou seja, para Kiarostami, a atitude documentarizante implica em oferecer não-ditos, pontos em aberto, para que o público preencha os espaços e chegue às suas próprias conclusões. No entanto, podemos questionar se esconder (diálogos apagados, no caso de Close-up) é o mesmo que deixar espaços para que o público os preencha com suas interpretações. O resultado final na relação com o público pode ser o mesmo, mas e a relação ética com Sabzian e Makhmalbaf, como fica? E se fizermos a pergunta de Bill Nichols "o que fazemos com as pessoas quando filmamos um documentário?" 127. Nichols diz que nos filmes de ficção a resposta é simples: "pedimos que façam o que queremos" ${ }^{128}$. No caso de Close-up, como Sabzian não fez exatamente o que Kiarostami desejava, o diretor interferiu na edição do som.

São inúmeras as possibilidades de interpretação quanto ao sentido do oculto em Kiarostami, onde podemos começar pelo papel do Imã Mahdi, nos estendermos para o sentido estético quando Kiarostami busca provocar a imaginação do espectador, mas sem dúvida não podemos ignorar o sentido ético. No discurso de Kiarostami, sobressai a idéia de que ele procura respeitar a intimidade de seus personagens, como no caso da

\footnotetext{
${ }^{125}$ Abbas KIAROSTAMI, “A arte da inadequação”, Folha de São Paulo, Caderno Mais, 17 Out 2004.

${ }^{126}$ Mehrnaz SAEED-VAFA, op. cit., p.107.

${ }^{127}$ In: Bill NICHOLS, Introdução ao Documentário, op. cit., p. 31.
} 
prostituta e da velha senhora em $D e z^{129}$, como o procedimento de não entrar no quarto dos personagens em Close-up, por hipótese, de não ouvirmos tudo o que os personagens dizem. Kiarostami afirma "nós podemos sentir e compreender sem ver". ${ }^{130}$ Nós acrescentamos, sem ver e sem ouvir. Assim, se Kiarostami cortou o som de Sabzian, queria preservar a intimidade do personagem, em seu desconhecimento do fato de que estava sendo filmado. Mas, paradoxalmente, Kiarostami engana o público ao simular uma falha técnica e engana Sabzian ao praticar um respeito pela metade: não exibe o diálogo, porém, mostra o personagem num encontro que poderia por si só ser constrangedor para Sabzian.

\subsection{Simulacro do simulacro}

Baudrillard citou Eclesiastes na epígrafe de seu Simulacros e Simulação: "O simulacro nunca é o que oculta a verdade - é a verdade que não existe. O simulacro é verdadeiro." ${ }^{131}$ Sem dúvida, um jogo de palavras provocativo e que encerra questões de importância filosófica inegável para o tema que envolve a reflexão sobre o real.

Baudrillard trabalha em cima de raciocínios voltados à ficção científica e sobre como os meios de comunicação de massa produzem realidade virtual. Por isso, inclusive, seu livro teria gerado a idéia do filme Matrix (Matrix, Andy Wachowski e Larry Wachowski, 1999). No primeiro longa, o personagem Neo, interpretado por

\footnotetext{
${ }^{128}$ Idem, ibidem.

${ }^{129}$ Kiarostami diz que a senhora que vai rezar na mesquita e a prostituta são faces da mesma moeda: "as duas atividades são muito privadas."In: "Entretian: Abbas Kiarostami - Des femmes réelles et non de cinema", Positif, n 499, op. cit. p.20.

${ }^{130}$ Abbas Kiarostami - Les yeux du coeur, entrevista a Stéphane GOUDET, Positif, 466, op cit, p. 12.

${ }^{131}$ Jean BAUDRILLARD, Simulacros e Simulação, op cit. p. 7.
} 
Keanu Reeves, guarda seus programas de paraísos artificiais no fundo falso de Simulacros e Simulação. Baudrillard disse que se os roteiristas se inspiraram no seu livro, não entenderam nada ${ }^{132}$.

Embora o foco reflexivo de Baudrillard não nos interesse diretamente aqui, alguns de seus conceitos em torno de simulacro dialogam com o que acontece no interior das cenas-chave que este trabalho se propõe a analisar. Por exemplo, Baudrillard afirma que "Dissimular é fingir não ter o que se tem. Simular é fingir ter o que não se tem. O primeiro refere-se a uma presença, o segundo a uma ausência." "133 Seguindo este raciocínio, Kiarostami dissimula na cena do corte do som, pois tem o diálogo entre Sabzian e Makhmalbaf e finge não ter. Já na cena do julgamento, Kiarostami, seguindo as definições de Baudrillard, simula, pois não tem os closes do juiz no momento real em que ele, diretor, entrevista Sabzian, porque o juiz não estava mais na sala.

Mais do que as seqüências do tribunal, as que envolvem a "falha do som", são as que Jean-Louis Baudry chamaria de simulacro do simulacro. Em Close-up, sua introdução é tão bem sucedida que pode ganhar inúmeros sentidos. E é tão convincente como um sonho que arranca de nós expressões do tipo "mas parecia verdade!" Pertinentemente, Baudry lembra o mito da caverna de Platão, que remete ao tema do real e da impressão da realidade como um marco da discussão teórica ${ }^{134}$. Tendo como proposição a abordagem psicanalítica, o autor avança na matéria utilizando Sigmund Freud. Tomando o sonho estudado por Freud no clássico A Interpretação dos Sonhos, Baudry afirma que o que diferencia o cinema do sonho é o caráter artificial do primeiro,

\footnotetext{
${ }_{132}^{132}$ Jean Baudrillard: A verdade oblíqua. Revista Época, 7 junho 2003.

${ }^{133}$ Idem, p. 9.
} 
mais exatamente o dispositivo. E chama a atenção para a idéia de que o cinema reproduz uma impressão de realidade, que faz emergir um "efeito-cinema" comparável à impressão de realidade ocasionada pelo sonho. Sonho, por sinal, que Pasolini chama de "realidade bruta" 135 .

Com ou sem psicanálise, com ou sem um mito fundador, e independente do acaso, estamos tratando de um axioma: a verdade. E provavelmente, em Close-up a verdade esteja na ficção, mesmo que quebrada em pedaços e apresentada como clivagem, onde o autor cria um (o seu) universo. E como o poeta (da Poética de Aristóteles), busca o universo ideal. Esta realidade ideal (da ficção) restitui à realidade da não-ficção uma plenitude que, segundo Ishaghpour, sem isto, não seria atendida por ela mesma. A mentira da arte como meio de retornar ao mundo. ${ }^{136}$

A verdade no cinema de Kiarostami é resultado de uma procura. Por exemplo, como Kiarostami encontrou o real no figurino de suas personagens femininas.Um dos aspectos que em geral não é percebido pelo espectador não familizarizado com o mundo islâmico, é quanto à vestimenta das mulheres nos filmes iranianos. No Irã, dentro das casas as mulheres não precisam cobrir os cabelos, porém, é uma obrigação religiosa, depois da Revolução Islâmica imputada por força de lei, que na rua, ou em qualquer lugar público elas usem o véu ${ }^{137}$. No cinema, isto sempre foi um problema para o realismo, que levou inclusive cineastas a driblarem e brincarem com a censura

\footnotetext{
${ }^{134}$ In: Jean-Louis BAUDRY, “Le Dispositif”, Communications, n’ 23.

135 Pasolini fala da comunicação visual que serve de base à comunicação cinematográfica, em contraposição à comunicação instrumental que serve de base à comunicação poética ou filosófica. Enquanto a primeira seria "extremamente rude, quase animal", a segunda seria "extremamente elaborada". In: "A poesia do nôvo cinema", op.cit., p. 269.

${ }^{136}$ In: Youssef ISHAGHPOUR, op. cit., p. 35.

${ }^{137} \mathrm{O}$ véu faz parte do hejab ("cortina", em árabe), o modo de vestir islamicamente correto. Estar hejab implica em cobrir o cabelo e usar uma capa que cubra pelo menos até os joelhos e não revele as curvas
} 
mostrando mulheres que, dentro de casa, estavam sempre com uma toalha de banho na cabeça (caso da cineasta Tahmineh Milani, que sempre cria alguma forma de suas personagens escaparem do véu quando estão dentro das casas). Kiarostami encontrou a sua solução para mostrar mulheres usando o véu sem que pareça irreal: opta por filmar mulheres na rua e dentro de carros, como em Dez, pois "é muito mais real""138, diz.

Através da busca pela espontaneidade dos atores (no caso, não profissionais), Kiarostami também encontra o real. É na região de Koker que ele filmou sua trilogia Onde Fica a Casa do Meu Amigo?, A Vida Continua (Va Zendegi Edameh Darad, 1992) e Através das Oliveiras. A região é como a Cinecittà particular de Kiarostami, que diz não ter sido ele que escolheu o lugar, mas o lugar que o escolheu. Gosta de lá porque as pessoas não estão familiarizadas com cinema e televisão. "Eu podia dirigi-las melhor; elas eram menos 'artificiais"”. ${ }^{139}$

Kiarostami não acredita no real no cinema: “A realidade só é possível quando se passa entre duas pessoas, desde que exista uma terceira pessoa, tudo muda. Sobretudo se esta terceira pessoa é o diretor que está filmando" ${ }^{140}$. No entanto, Kiarostami busca uma solução para que o falso pareça real. E é assim que ele define o curta minimalista $O$ Pão e o Beco, seu primeiro filme, sobre um menino que precisa passar por uma viela para

femininas. O shador (pano preto que em árabe significa "tenda") é exigido apenas para entrar em mesquistas.

${ }_{138}$ Patrice BLOUIN e Charles. TESSON “Ten - Elimination de l'auteur”. Cahiers du Cinéma, n ${ }^{\circ}$ 571, set 2002, p. 15.

${ }^{139}$ In: "Entretian: Abbas Kiarostami - Des femmes réelles et non de cinema". Entrevista a Michel CIMENT e Stéphane GOUDET, Positif, nº 499, p. 18.

${ }^{140}$ Patrice BLOUIN e Charles. TESSON “Ten - Elimination de l'auteur”. Cahiers du Cinéma, op. cit., p. 20. 
chegar em casa e é interceptado por um cão. Ele diz que não criou o menino, nem o cão, nem o medo do menino pelo cão, ele somente juntou esses elementos e os registrou. ${ }^{141}$

Já em Close-up, Kiarostami parece cair em uma contradição. Ou, por outro lado, a busca por uma solução que levasse ao realismo repercutiu de outra forma. Ao cortar o som na encenação/ficção do encontro de Makhmalbaf e Sabzian, o diretor abriu nova camada de percepção para o público, justamente fazendo lembrar que por trás de um defeito técnico, simulado ou não, há um filme sendo feito e é preciso duvidar do que se vê e do que se ouve. Neste sentido, Kiarostami desnaturaliza o cinema ao não reproduzir a aparência e provoca a sensação de que o mundo não é o que vemos.

Por não ser o que parece, Close-up suscita questões polêmicas, que podem ser disputadas no campo da sociologia, da antropologia (e mais estritamente do cinema etnográfico), da estética, da filosofia, e que estão, também, circunstancialmente na pauta da imprensa diária. A referência aqui é ao documentário de Michael Moore, Fahrenheit 9,11, e o uso do filme para não reeleger George Bush. É para isto que serve o cinema? Cabe a um cineasta intervir na realidade? É certo que a intervenção de Kiarostami na realidade surge de um modo latente - ele não tem propósitos definidos como Moore mas acaba tornando-se uma evidência. Assim como Onde Fica a casa do Meu Amigo? deu origem a E a Vida Continua, tratando do terremoto e obrigando as autoridades iranianas a se voltarem para a tragédia ${ }^{142}$, em Close-up, Kiarostami define o destino de

\footnotetext{
${ }^{141}$ A propósito do cão, perguntado pelo cineasta português Manoel de Oliveira como ele tinha conseguido dirigir o animal, Kiarostami respondeu que eram todos não-profissionais naquele filme: o menino, o viralata e ele, por isso tudo teria dado tão certo. In: Ivonete PINTO, "O princípio da imagem", Teorema Crítica de Cinema, ${ }^{\circ}$ 6, p. 27.

${ }^{142}$ No entanto, Antoine de BAECQUE observa que o cinema de Kiarostami sempre chega tarde. Em E a Vida Continua, a equipe chega no local três dias após o terremoto, isto na ficção do filme, pois na realidade a película foi rodada cinco meses após a tragédia. In: "Le réel a tremble", Cahiers du Cinéma, 461, p. 31. Se persarmos melhor, veremos que em Close-up acontece o mesmo, com Kiarostami chegando após a prisão de Sabzian. E acrescentaríamos que em Dez o mesmo ocorre, com Kiarostami
} 
seu personagem. O estelionatário Hussein Sabzian teve a complacência do juiz e conseguiu sua absolvição-liberdade (e, talvez, o perdão da família Ahankhah). Kiarostami interviu na realidade mesmo que seu objetivo fosse apenas registrar e entender a alma do anti-herói Sabzian.

Esta discussão é vital para o estabelecimento da conexão fato-fantasia. Pois se Kiarostami tem o inalienável direito de fazer ficção (inventar), porque é da ontologia do cinema fazê-lo ou, em outras palavras, é "pecado original inscrito na técnica"143 do cinema, numa perspectiva dialética seria legítimo questionar se Kiarostami pode mentir para interferir nos fatos extra-fílmicos. Ou, caso a legitimidade da indagação seja contestada, podemos tentar entender por que o esforço de Kiarostami de simular o simulacro e "na vida real" falsear sobre as razões do simulacro.Quando podemos acreditar em Kiarostami? É preciso acreditar em Kiarostami?

\subsection{Cinismo sincero}

Depois de termos desenvolvido a análise em torno das cenas do julgamento e do corte do som, é o momento de voltar à pergunta sobre ser Kiarostami um ator cínico ou sincero.

tomando conhecimento pelo jornal de que uma psiquiatra, impedida de clinicar no consultório, atendia as clientes no carro.

${ }^{143}$ Expressão tomada de Ismail XAVIER: “(...) o que dificulta a consolidação de linguagens alternativas "mais verdadeiras"” é esse pecado original inscrito na técnica". In: O Olhar e a Cena, p. 49. 
Se nos colocarmos no papel do público do cinema praticado por Kiarostami, propenso e ávido por momentos de realismo na tela, diríamos que somos como os doentes, os compradores de sapato de tamanho errado e as senhoras ansiosas por pneus bem calibrados. Compramos o corte do som e o realismo improvável do julgamento, parte por ignorarmos tecnicamente tanto as possibilidades do uso do som como as especificidades de um tribunal regido pela sharia, parte porque queremos ser enganados. Mais do que acionarmos a suspensão do descrédito ${ }^{144}$, damos vazão à nossa necessidade de acreditarmos e admirarmos um diretor que vai ao limite da autenticidade e mantém na montagem final um problema técnico, porque, afinal, tratava-se de um "flagrante da realidade".

Jean-Claude Bernardet, que viu Close-up com a cineasta Tata Amaral, em seu Caminhos de Kiarostami, admite que poderia ter percebido a falha do som como um truque, mas não o fez:

Tínhamos informações técnicas suficientes para perceber a operação que estava em curso, poderíamos ter pelo menos desconfiado, porém não desconfiamos de nada e preferimos nos emocionar intensamente. ${ }^{145}$

Kiarostami, por seu turno, é cínico, utilizando o termo de Goffman, porque "brinca à vontade com alguma coisa que o público deve levar a sério". ${ }^{146}$

\footnotetext{
${ }^{144}$ Suspensão do descrédito, ou da descrença, termo de Samuel Taylor Coleridge, poeta inglês (17721834), precursor do romantismo, que se referia à momentânea suspensão voluntária da incredulidade do leitor diante de obras que exprimem crenças ou filosofias diferentes das nossas.

${ }_{145}^{14}$ : Jean-Claude BERNARDET, Caminhos de Kiarostami, op. cit., 139.

${ }^{146}$ In: Erving GOFFMAN , op. cit., p. 26.
} 
Aliás, brincar nos sugere o exame do jogo como artefato narrativo em Kiarostami. Acreditamos que no jogo proposto por Kiarostami esteja uma das folhas do passaporte para a problematização da verdade e da mentira.

Antes de Close-up, dois personagens de crianças já contavam com objetos que adquirem um caráter lúdico e constituem praticamente um modelo operacional para o diretor. Trata-se de $O$ Viajante, onde o personagem usa a câmera sem filme para enganar seus clientes (que querem ser enganados?), e em Onde Fica a Casa do meu Amigo?, onde um caderno é o objeto que promove a jornada do personagem.

Como já destacamos no capítulo A manipulação do artifício (Procedimentos), Kiarostami lança as regras do jogo explicitamente para Sabzian na cena do julgamento, quando explica como funciona a "brincadeira" (uma câmera pega você em plano aberto, outra em close).

Em Reflexões Sobre a Criança, o Brinquedo e a Educação, Walter Benjamin examina, segundo palavras dele, a grande lei que rege a totalidade do mundo dos jogos, que é a lei da repetição. Essa lei seria a alma do jogo para a criança, pois que nada a torna mais feliz do que o "mais uma vez". A obscura compulsão por repetição, conforme Benjamin, tem relação com o impulso sexual no amor:

E não foi por acaso que Freud acreditou ter descoberto um "além do princípio do prazer" nessa compulsão. E, de fato, toda e qualquer experiência mais profunda deseja insaciavelmente, até o final de todas as coisas, repetição e retorno, restabelecimento da situação primordial da qual ela tomou o impulso inicial. $^{147}$

${ }^{147}$ In: Walter BENJAMIN, Reflexões Sobre a Criança, o Brinquedo e a Educaçã, p. 101. 
A experiência da repetição em Kiarostami, concernente ao universo dos jogos, encontra sua maior alegoria nos objetos que rolam (lata de spray, toco, osso, maçã) e nos caminhos em ziguezague que aparecem em Através das Oliveiras, 10 on Ten, e, de modo pictórico em Onde Fica a Casa do meu Amigo?. Em O Vento nos Levará, há a repetição de uma ação, onde o personagem sobe diversas vezes uma colina para obter sinal para o celular. A repetição se estende, dia após dia, ao teor dos telefonemas dados nesta ação, pois a fala é sempre a mesma (a informação de que nada mudou no lugar).

A repetição em Kiarostami, principalmente em objetos que rolam e traços que representam em si próprios a repetição, parece compor um sistema organizador que se reflete em filmes de diferentes épocas. Uma repetição construída cenograficamente, que quer revelar-se como simbólica e propõe, renovadamente, que o jogo continue. Os brinquedos podem mudar, Kiarostami pode quebrar as regras do jogo, mas o lúdico moto-contínuo permanece.

Walter Benjamin defende que o brinquedo, "mesmo quando não imita os instrumentos dos adultos, é confronto, e, na verdade, não tanto da criança com os adultos, mas destes com a criança." ${ }^{, 148}$.

Benjamin também fala em "objeto de culto" para referir-se a bolas, pipas e outros brinquedos antigos que, graças à força da imaginação infantil transformaram-se efetivamente em brinquedos. No caso das duas câmeras oferecidas a Sabzian, este objeto de culto é evidente. A câmera é para o cineasta o que a bola é para um jogador de

\footnotetext{
${ }^{148}$ Idem, p. 96.
} 
futebol. Ao admirar os filmes de Makmalbaf, Sabzian já admirava a "maquininha" que possibilitava que eles fossem feitos. Se Sabzian também pudesse ter a sua, poderia brincar ainda de forma mais convincente de ser Makhmalbaf. Durante Close-up, ao menos, ele brincou de ser o dilacerado personagem de $O$ Ciclista e brincou de ser o Imã Hussein, deixando-se açoitar em público durante o filme. Notemos que nada do que acontece em Close-up é compulsório. Todos participam do filme porque aceitaram, porque quiseram (mesmo que, no caso de Sabziam, aconselhado por Makhmalbaf e pelo juiz). E esta é para Huizinga a condição do jogo: uma atividade voluntária.

Em Homo Ludens - O jogo como elemento da cultura, Johan Huizinga, diz que mesmo as crianças, às quais se poderia contestar o livre arbítrio, a sua liberdade reside no fato de gostarem de brincar. Conforme o autor, o jogo também apresenta a característica de não ser a vida "corrente" nem a vida "real". "Pelo contrário, trata-se de uma evasão da vida 'real' para uma esfera temporária de atividade com orientação própria." ${ }^{149}$ E completa: “Toda criança sabe perfeitamente quando está 'só fazendo de conta' ou quando está “só brincando.",150

Huizinga chama a atenção para o fato do jogo ser caracterizado pelo isolamento, pela limitação. Um jogo, pata ser um jogo, é jogado até o fim, dentro do tempo e do espaço estabelecidos. Para ele, dentro de uma regra específica e absoluta, existe uma ordem suprema: “a menor desobediência e esta 'estraga o jogo', privando-o de seu caráter próprio e de todo e qualquer valor." 151

\footnotetext{
${ }_{149}^{14}$ : Johan HUIZINGA, Homo Ludens - O jogo como elemento da cultura, p. 11.

${ }^{150}$ Idem, ibidem.

${ }^{151}$ Idem, p. 13.
} 
Neste sentido, e mais uma vez, a cena do corte do som contribui com alta carga de simbolismo. O diálogo entre Sabzian e Makhmalbaf na saída da prisão, subtraído por Kiarostami, revelaria que o primeiro estava prestes a "estragar o jogo". Se ele não participasse do filme, não haveria jogo. E Makhmalbaf, naquele momento, o que fez foi "salvar o jogo" ao argumentar, com êxito, que seria bom para Sabzian fazer o filme. Como o público não conhece este diágolo, o jogo que Kiarostami opera é outro, é o do cinismo conceituado por Goffman. Kiarostami faz, de fato, um metajogo, pois passa a incluir o público na brincadeira.

Terminado o filme, acaba o jogo? Para Makhmalbaf e o público provavelmente sim, para Kiarostami, talvez (a carreira do filme poderia determinar o seu futuro), mas para a família Ahankhah e Sabzian, o jogo continua. A despeito de possíveis vantagens que a família pudesse conseguir (a "celebridade", o orgulho de ter participado de um filme de Abbas Kiarostami), continuaria morando no mesmo lugar e sua imagem não estaria dissociada da vítima ingênua que caiu no conto de um vigarista. Sabzian somaria a uma certa celebridade, a vergonha de ter dado um golpe em nível criminal (sobre o destino de Sabzian após o filme ver o anexo Descrição comentada do filme Close-up Long Shot).

A questão ética, portanto, entra para questionar um jogo cujas regras internas, entre elas a de terminar no momento estipulado, valeram apenas para alguns dos envolvidos.

Sem nos desviarmos da questão do jogo, pelo contrário, para entendê-lo melhor, Huizinga vai em uma direção que nos interessa aqui, que é a natureza e origem dos 
conceitos religiosos. O autor de Homo Ludens diz que "quando uma certa forma de religião aceita uma identidade sagrada entre duas coisas de natureza diferente, como por exemplo um ser humano e um animal, não podemos definir corretamente esta relação como uma 'ligação simbólica'."152 Segundo Huizinga, mais do que simplesmente uma relação simbólica, a identidade destes seres diferentes é mística, "um se tornou o outro", diz (o exemplo com que o autor trabalha é o de uma dança, onde o selvagem se torna um canguru).

Huizinga tem o cuidado de lembrar que desconhece os hábitos mentais de um selvagem e que, portanto, "traduz" o selvagem a partir dos meios de expressão que ele (Huizinga) conhece: "Exprimimos a relação entre e o animal com o qual se identifica como sendo uma 'realidade' para ele, e um ‘jogo' para nós. O selvagem diz que se apoderou da 'essência' do canguru, e nós dizemos que ele 'brinca' de canguru."

Embora sejamos tentados aqui a desenvolver uma analogia, colocando Sabzian no papel de um selvagem que incorporou Makhmalbaf em sua "dança", estaríamos ignorando a capacidade de Sabzian interpretar sua ação. Seu discurso de autodefesa no julgamento, invocando seu amor pelo cinema (tema que move todos os envolvidos), engendra uma sofisticação manipulatória que nos desautoriza a pensá-lo como selvagem. Nem mesmo o era Nanook, de Robert Flaherty, que só apareceu como tal na tela devido à montagem a serviço de uma tese: o público deveria ver Nanook como "o bom selvagem".

${ }^{152}$ Idem, p. 29. 
Já Sabzian é um ingênuo, um tanto infantil (uma criança mesmo, como admite Kiarostami em entrevista ao documentário já citado, de Jamsheed Akrami), um ser obcecado incapaz de medir as conseqüências de suas mentiras. Agiu num tal nível de leviandade em relação à mentira, que ficou habitando outra esfera na sociedade, a de um borderline que chegou à prática de um crime, levando-o ao tribunal. Ora, se Sabzian não é o selvagem, nos interessa aqui o fenômeno daquele que "se torna o outro". A identidade de Sabzian ficou tão afetada com a farsa que a última frase do filme é dita no portão em frente à casa dos Ahankhah. Levado por Makhmalbaf, Sabzian aciona a campainha e identifica-se: "Aqui é Sabzian". Após um instante de silêncio em que parece não ter sido identificado, corrige-se: “Makhmalbaf”. Só então é reconhecido.

Se isto foi uma fala espontânea de Sabzian ou criada por Kiarostami, não sabemos, tudo é possível. O que é importa é o valor da fala: Sabzian só existe como Makhmalbaf. Ele se tornou o outro, numa operação mística, a mesma que leva o personagem de $A$ Vaca, citado no capítulo Realismo Poético, a intitular-se: "Eu não sou Mashd Hassan, eu sou a vaca de Mash Hassan”. E a mesma operação mística que faz com que fiéis xiitas açoitem-se durante a Ashura, assumindo as dores de Hussein. Naqueles momentos da cerimônia de Karbala, todos são Hussein.

Portanto, é por demais familiar a Kiarostami este aspecto do jogo implicado ao misticismo. Não é à toa que o diretor assumiu imediatamente o projeto ao tomar conhecimento da história, passando inclusive por cima da vontade de Makhmalbaf, que teria se interessado primeiro (o próprio Makhmalbaf teria ligado para Kiarostami para contar-lhe da notícia na revista Soroush sobre a prisão de Sabzian). 
Neste jogo de "ser outro", Sabzian não é vicário de Makhmalbaf, no sentido de que não o substituiu, mas o incorporou, tornou-se o outro. A conclusão que chegamos é que Sabzian é igual ao menino falseador de $O$ Viajante que tirava fotos em uma câmera sem filme. Ambos, durante o jogo tornaram-se aquele pelo qual faziam-se passar. Não temos acesso ao processo mental destes personagens, interpretados, neste sentido, como de igual para igual, como frutos da ficção, mas somos levados a acreditar que eles, como crianças, têm consciência do faz-de-conta subjacente à lógica dos jogos. O que não podemos ser conclusivos ainda é quanto ao papel do adulto que propõe o jogo (Kiarostami) está dentro ou fora dele, submetido ou não às regras internas do mesmo. Já demonstramos que Kiarostami pode ser cínico (segundo Goffman), mas o quanto e como ele manipula e constrói artifícios, que poderiam ser tratados como mentiras, isto ainda fica em pendente.

\section{9 - Imagens suspeitas}

A idealidade no cinema de Kiarostami; o realismo na literatura; o "carimbo" de autenticidade que o diretor imprime em Close-up. 
Há algumas maneiras de enfrentar diretores que trabalham com imagens (supostamente) documentais. Duas delas poderiam ser: tentando unir o que é verdade e o que é mentira numa só gênese-gênero, ou enfrentando-os pela perspectiva da contradição. Na primeira, um deus Janus de duas faces, anjo e demônio em um só corpo. Na segunda opção, aceitaríamos a impossibilidade da síntese-simbiose entre verdade e mentira, ficção e não-ficção, e trabalharíamos com a contradição como valor, em aproximação com o conceito de inverdade, termo que sugerimos no artigo $O$ cinema inverdade de Kiarostami ${ }^{153}$.

Partindo do discurso do próprio Kiarostami poderíamos ainda admitir uma terceira via de leitura: a via que transforma verdade+mentira, amalgamadas, num substantivo novo, a ser pensado. Algo que se poderia chamar de "idealidade", ou seja, estratos de realidade e fantasia porosos, que se contaminam e que formam o (um) ideal do cineasta. Este ideal kiarostâmico surge exatamente do domínio das ferramentas de uma ficção que procura por um certo realismo. Em uma das lições de 10 on ten (2004), Kiarostami diz: "Na estética do cinema, creio que o primeiro passo é quebrar a realidade. Na prática, separamos as coisas e, com um novo agenciamento, obtemos uma nova coisa diferente da realidade corrente."

Separar as coisas significa isolar o que é real do que não é, reordenando os dados e criando algo novo a partir daí. Este parece ser, ainda que torto, o imperativo categórico de Kiarostami. Separar é, pois, manipular e manipular, por sua vez, é

\footnotetext{
${ }^{153}$ In: CATANI Afrânio Mendes [et al.] (org.), Socine - Estudos de Cinema, "O cinema inverdade de Kiarostami”, Ivonete PINTO, p. 320-328.
} 
"imprimir formas, forjar e maquinar situações e contribuir para o funcionamento de um conjunto de idéias e crenças" ${ }^{\prime 154}$.

Por real, convém reforçar que não se trata de um conceito em que todas as áreas do conhecimento comunguem. Sob o ponto de vista da sociologia, por exemplo, Paulo Menezes, no artigo Representificação, lembra que os primeiros estudiosos do funcionamento das sociedades humanas já sugeriam três possibilidades de real: “...três reais absolutamente diversos, nenhum deles, além de tudo, passível de ser apropriado diretamente pelos olhos, nem mesmo os dos positivistas."155

Já o estado do que é real, o realismo, parece ser uma busca que cada vez mais cresce e atinge todas as áreas. Nas artes plásticas, experimentos à procura do realismo formam uma demanda recorrente. A Bienal da Taipei (2006/2007) teve como título Você Acredita em Realidade? Com este quesitonamento, as obras procuraram pensar a documentação da realidade. Um dos artistas, o performer Chen Chieh-Jen, organizou numa antiga fábrica de confecções desativada, uma ação com ex-operárias, agora idosas, que retomaram suas atividades de décadas anteriores.

Mas a exposição Corpo Humano: Real e Fascinante, parece-nos uma proposta mais radical no intuito de pensar o realismo. A exposição itinerante que teve caráter educativo e já esteve em diversos países, ${ }^{156}$ foi composta por 16 corpos inteiros e mais de 225 partes e órgãos - alguns deles podiam ser manuseados. Tantos os corpos quanto os órgãos foram preservados com a técnica da polimerização, uma espécie de

\footnotetext{
${ }^{154}$ In: Sidney FERREIRA LEITE, O Cinema manipula a realidade?, p. 6.

${ }^{155}$ No artigo "Representificação", Paulo MENEZES refere-se aos conceitos de Émile Durkheim, Max Weber, Karl Marx e Walter Benjamin. In: Revista Brasileira de Ciências Sociais, p. 89.

${ }^{156}$ No Brasil a exposição teve lugar em São Paulo, na Oca, e aconteceu durante o mês de março/2007.
} 
plastificação da matéria em que os tecidos são esvaziados de água e preenchidos com borracha líquida de silicone. Ou seja, são corpos reais, mas que ao mesmo tempo não são vistos como absolutamente reais em função tratamento químico que receberam. Um real manipulado, através do qual podemos fazer um paralelo com o cinema de Kiarostami, que não deixa de ser real, mas que ganha outra dimensão.

Iniciativas como estas nos fazem pensar no realismo como espetáculo. Para Jean-Louis Comolli, estaria aí justamente a primeira definição de realismo cinematográfico: um espelho da realidade onde o espírito, o estilo, os efeitos, o sistema de escritura nos garantem que o espetáculo tome o lugar da vida, que a experiência vivida pelo espectador no espetáculo (a projeção de um filme) não seja estranha.

Em Filmar para ver, Comolli diz que, em Kiarostami, estamos sempre diante da mesma pergunta: de que maneira viver sua própria vida se não através da irremediável propagação do espetáculo? Para Comolli, de Rosselini a Kiarostami, das ruínas de Berlim (Alemanha Ano Zero, 1947) ao terremoto de A Vida Continua, passando pela matança de Strombolli (1949), “a morte, a destruição, a ruína do mundo antigo adquirem formas terrivelmente reais, simplesmente porque se impõem a nós, espectadores, como as condições mesmas do espetáculo que estamos vivendo" ${ }^{\text {"157 }}$. Cada novo realismo seria então uma operação de desconstrução de realidades anteriormente postas e a partir de agora desmontadas.

\subsection{Manuscritos medievais}

${ }^{157}$ Jean-Louis COMOLLI. Filmar para ver-Escritos de Teoría y crítica de cine, p. 191. 
Se continuarmos a observar o que se entende por realismo, vemos que na literatura, ao menos desde Flaubert, ele foi ultrapassado como estética. Apoderar-se de fait-divers e transformá-los, como fez Flaubert com Madame Bovary, era um exercício de criação, onde não cabia a cobrança de reprodução precisa de fatos. Além do que, o escritor francês não estava interessado em reproduzir pura e simplesmente conteúdos de notícia de jornal.

Já não era o que acontecia com Montesquieu. A ele interessava o contrário, isto é, partir de geografias e situações inventadas (por ele), mas que parecessem ser verídicas. Renato Janine Ribeiro, tradutor de Cartas Persas, afirma no prólogo do livro que era costume no século XVIII a prática do romance epistolar, onde o autor, que muitas vezes não se identificava, dizia ter encontrado cartas das quais ele passaria a narrar o conteúdo, ou pelo menos parte dele. Janine Ribeiro também lembra que, assim como na introdução de Choderlos de Laclos em As Relações Perigosas, Montesquieu prometia trazer à luz o resto da história, caso os leitores manifestassem interesse. "Mas percebe-se que isto era somente uma convenção; sabia-se que as tais cartas eram de autoria do próprio editor(...)." ${ }^{158}$ Montesquieu escreve na Introdução: "Selecionei estas primeiras cartas para provar o gosto do público; disponho de bom número de outras em minha pasta, que poderei editar mais tarde." ${ }^{159}$ Montesquieu, que publicou Cartas Persas em 1721, nunca foi à Pérsia e teria se inspirado nas cartas de viagens de dois franceses.

\footnotetext{
${ }^{158}$ In: MONTESQUIEU, Cartas Persas, trad. Renato Janine Ribeiro, p. 09.

${ }^{159}$ Idem, p. 13.
} 
Inspirado, por sua vez, na prática de Montesquieu, Umberto Eco usa uma variação desta artimanha em $O$ Nome da Rosa. O escritor italiano, antes ainda do prólogo, afirma que achou aquela história que passará a contar em manuscritos medievais perdidos. Eco faz paródia a este recurso tradicional em que o autor dizia que, por herança, tinha recebido um manuscrito, o que atestaria a autenticidade da história narrada. Recurso que segue fazendo escola. É utilizado também pelo Nobel de Literatura de 2006, Orhan Pamuk. No prefácio do livro O Castelo Branco, assinado por um pseudônimo do autor, Faruk Darvinogluif, o escritor turco diz que encontrou "este manuscrito (...) no fundo de uma cômoda empoeirada e cheia até a boca de decretos imperiais..." 160

O Código da Vinci é outro exemplo. O best-seller de Dan Brown abre com um capítulo chamado "Fatos". É como se ele dissesse: a partir de agora, caro leitor, você vai encontrar a verdade sobre os acontecimentos envolvendo a vida de Jesus Cristo, pois meu livro trabalha com a verdade.

Este "Fatos", em $O$ Código da Vinci tem o mesmo valor que a abertura de Close-up, onde Kiarostami nos créditos mostra a rotativa de um jornal sendo impresso, trazendo a capa com a manchete sobre a prisão do falso Makhmalbaf. O que equivale a afirmar: caro espectador, o que você verá a partir de agora é verdade, ou seja, fatos. O letreiro informando "baseado em fatos reais" tem uma força infinitamente menor do que as imagens do jornal. A rotativa funciona como um carimbo de fato real, somada à presença do jornalista antes ainda dos créditos, gerando um sistema coeso de realidade incontestável.

\footnotetext{
${ }^{160}$ In: O Castelo Branco, de Orhan Pamuk, p. 10. Segundo nota do tradutor (Raul de Sá Barbosa), Faruk
} 
Ou seja, a estratégia que Kiarostami utiliza em seu filme vem de uma tradição que remonta ao século XVIII, quando escritores usaram do recurso de cartas/ manuscritos para chamar a atenção do leitor quanto à veracidade dos fatos.

Ainda na literatura, mas retrocedendo mais de dois mil anos, Aristóteles já defendia na Poética que o poeta (e mesmo o historiador) não deve ater-se ao relato de acontecimentos. Para isto, lança mão da mímesis para re-presentar, ou voltar a apresentar o objeto.

Ao poeta Kiarostami, no sentido aristotélico, não se questiona a prerrogativa de recriar os fatos sem que isto deixe de se chamar realismo. Mas detendo-nos no aspecto da verdade e da mentira e o que isto significa no contexto da sétima arte, temos que desde o nascimento do cinema mistura-se realidade e ficção. Nos primórdios, a questão da veracidade não representava um problema, era apenas "teatro filmado" nas experiências dos irmãos Lumières com câmera fixa. Quando Méliès inventou as trucagens é que as complicações surgiram. E quando os ingleses mandaram cinegrafistas para cobrir a Primeira Guerra Mundial e o material captado passou a ser selecionado, montado, é que o real se configurou em impossibilidade.

A partir do momento que o cinema passou a ser analisado com a preocupação do realismo (Bazin) e, à luz da psicanálise e da filosofia (Metz e Deleuze) esta preocupação é estendia à dimensão da ética, entendemos como uma contribuição importante problematizar as opções estético-éticas de Kiarostami cujos discursos, dentro e fora da tela, estão recheados de concepções em torno do real, do realismo e da verdade.

Darvinogluif , o pretenso descobridor e editor do "manuscrito", é também personagem de outro livro de Pamuk, Sessiz Ev. (p. 168) 


\subsection{A rotativa em Close-up}

Antes de analisar a rotativa como recurso utilizado por Kiarostami para promover a impressão de realidade, cabe lembrar que o diretor, até mesmo em um filme ficcional como Gosto de Cereja, lançou mão de um meio semelhante para colocar-se diante do espectador como um cineasta que valoriza o realismo e seu atributo mais direto, a verdade. No final do filme, como um posfácio, Kiarostami entra em cena com a equipe, sendo esta imagem captada em vídeo. Ou seja, o espectador teve acesso a uma segunda câmera, cujo papel era o de informar que o que fora visto até então era ficção, a partir dali seria não-ficção.

Kiarostami de fato tem apreço pelo que Rubén García Aljarilla chama de "sensação de realismo". Ele diz que em todos os filmes de Kiarostami se produz uma demonstração dos mecanismos de representação. Esta demonstração, para ele, adquire um papel protagonista que contribui para que a sensação de realismo seja maior.

O fato de que se advirta de antemão que o que é visto é uma falácia provoca que o grau de confiança no diretor seja maior. Se uma câmera está filmando a outra câmera, você como espectador pode se dar conta de que o que filma a outra câmera é artificial. ${ }^{161}$

Podemos estender este raciocínio para a rotativa, cuja materialidade tem origem no jornalismo.

\footnotetext{
${ }^{161}$ In: Rubén García ALJARILLA. Abbas Kiarostam. http://www.comunicacionymedios.com
} 
Antes da invenção e propagação do rádio como veículo de informação, à imprensa escrita cabia a tarefa de reportar e repercutir acontecimentos. No entanto, possivelmetne porque o rádio não traga imagem, o cinema preferiu lançar mão da materialidade dos jornais para transformar uma informação em imagem e para, principalmente, dar ao espectador o sentido de autenticidade, já que o senso comum trabalha com a idéia de que se saiu no jornal, é verdade. Assim, a rotativa nos filmes equivale em simbologia aos manuscritos medievais que a literatura utilizou. E, assim como na literatura, a rotativa no cinema funciona como uma convenção da narrativa para remeter à verdade daquele enredo. $\mathrm{O}$ espectador sabe, por exemplo, que a página de jornal que estampa o assassinato de uma prostituta em Scoop (Woody Allen, 2006) é uma peça do jogo da ficção.

Mas como a rotativa funciona em um filme de não-ficção, quando uma página de jornal aparece sendo impressa trazendo a notícia da prisão da pessoa real da qual o filme está tratando? Funciona como um clichê para reforçar a natureza documental do filme, levando-nos a supor que o espectador "compra" a página de jornal como documento a atestar a existência desta figura até então anônima chamada Hussein Sabzian, seu crime e sua prisão. Aqui, porém, não cabe discutir se a referida página de jornal é falsa ou não. Muito provavelmente ela substitui na narrativa a revista (Soroush Magazine), onde Kiarostami diz ter lido a notícia sobre Sabzian. E a página do jornal pode ter sido rodada especialmente para o filme, já que no Irã o papel jornal é subsidiado pelo governo, o que torna o custo de qualquer impressão bastante baixo e o que explica o grande número de jornais existentes no país. 
No lugar da rotativa, o filme poderia ter optado por uma reportagem de TV que trouxesse o fato, mas, além disto demandar um esforço de produção maior, é preciso lembrar que no Irã existem poucas emissoras, todas controladas pelo governo, sendo que o veículo televisão não é popular no Irã. De outra forma, Kiarostami poderia ter optado por mostrar a própria página da revista com a reportagem sobre a prisão de Sabzian, mas supomos que esteticamente não funcionaria, pois a rotativa, afora representar mais um elemento que rola nos filmes de Kiarostami, tem o caráter de “calor da hora", impregnado, por si só, de um realismo muito mais pungente que uma página sem movimento.

Importante ressaltar que o momento em que Kiarostami introduz a rotativa é um momento não diegético, durante os créditos, quando o espectador começa a inteirar-se da história. O espectador é incitado, então, desde o início a compactuar com a idéia de que o filme é um documentário, que mostrará fatos acontecidos (mesmo que reencenados, como fica claro na cena do micro ônibus, quando Sabzian conhece a senhora Ahankhah), e que é possível confiar no que será visto no decorrer do filme.

Outro elemento que nos permite pensar que Kiarostami quer comunicar ao espectador que o que está mostrando é registro documental, é sua entrada em cena (tal como no final de Gosto de Cereja) no momento em que, na visita à prisão, convida Sabzian para participar do filme. Jean-Louis Comolli corrobora esta hipótese, ao afirmar que os filmes ditos documentais mostram que eles também necessitam do mesmo tipo de garantia, de prova de autenticidade ou de não-fraudulência. Comolli sustenta que a fórmula desta garantia documentária traz algumas condições, entre elas: "o nec plus 
ultra [o que há de melhor] no documentário, é o corpo filmado do cineasta." ${ }^{162}$. Comolli assegura que a entrada em cena do corpo do autor aumenta o valor do conjunto corpopalavra-assunto-experiência-vida por lhe dar menos "falsicabilidade".

Ao filmar-se, o autor garante com a sua persona a força desta confusão que dá toda a singularidade do cinema documental. $O$ corpo filmado do cineasta impõe uma prova da essência documental do filme, capaz de produzir um efeito de verdade que dispensa o que discutir. ${ }^{163}$

Tanto o corporalidade do autor como a corporalidade da notícia/verdade através da rotativa, damos o nome de carimbo de real. Um carimbo que Orson Welles utilizou ao limite em Cidadão Kane (1941). A diferença, porém, é que o filme de Welles insere-se no chamado newspaper movies ${ }^{164}$, um gênero que trabalha com enredos sobre a relação do cinema com o jornalismo. No caso de Cidadão Kane, o jornal aparece duplamente como parte do enredo e como recurso narrativo, pois vai contando a história de Kane. Já em outro exemplo de newspaper movie, Todos os homens do presidente (All the president's men, Alan Pakula, 1976), vamos encontrar o jornal como personagem incorporado à narrativa (o Washington Post, que investiga a invasão na sede do Partido Democrata americano, dá origem ao escândalo Watergate e à queda do presidente Richard Nixon) e como cenário de toda trama.

Portanto, Close-up não se filia a este gênero, apesar de inclusive contar com um jornalista como desencadeador dos fatos. Close-up insere-se, talvez, no gênero cinema movie, onde estaria ao lado de títulos como A Noite Americana (La Nuit Américaine, François Truffaut, 1973) e Viva o Cinema (Salaam Cinema, Mohsen Makhmalbaf,

\footnotetext{
162 Jean-Louis COMOLLI. "L'anti spectateur, sur quatre film mutants". Images Documentaires, p. 11.

${ }^{163}$ Idem, ibidem.
} 
1995) - e vários filmes de Jean-Luc Godard, entre eles O Desprezo (Le Mépris, 1963), pois é um filme que pensa o cinema. Close-up coloca Kiarostami pensando o próprio meio, traço que lhe confere uma inquestionável moderninade.

\section{0 - A verdade (relativa) do cinema}

\footnotetext{
${ }^{164}$ Mais informações sobre cinema e jornalismo no livro From Headline Hunter to Superman - A journalism Filmography, de Richard R. Ness, registrado nas Referências Bibliográficas.
} 
A realidade buscada por Kiarostami em seu discurso sobre cinema; a verdade segundo Habermans; os diretores influenciados por Kiarostami e as imagens transgênicas.

Rithy Panh, diretor cambodjano incensado pelos documentários de denúncia às atrocidades do Kmer Vermelho, disse que a verdade contida nos seus filmes não é a verdade dos personagens, ou do real, mas a sua verdade. ${ }^{165}$

Mais ou menos como dizer "a verdade do cinema", uma variável do discurso de Kiarostami e tantos outros diretores que trabalham com imagens do real, como o mestre deste assunto, Jean Rouch, para quem o cinema não se referia à verdade, o cinema instaurava sua própria verdade.

Não se trata de negar este direito ao autor. Aliás, reiterando, mais do que um direito, manipular, no sentido de prever uma mise-en-scène através da decupagem e propor sentidos através da montagem, é da essência do cinema. De qualquer forma, manipulando ou não com os fatos, com os recursos próprios do cinema, o espectador jamais terá acesso a uma realidade que não seja mediada, interpretada, que seja nua. $\mathrm{O}$ que se coloca aqui em discussão é o significado e a importância do real em Kiarostami, considerando inclusive seu discurso quanto ao tema. Em 10 on Ten, Kiarostami afirma: “Antes de mais nada, um artista precisa ser realista. É preciso perseguir a realidade, mesmo se nós não a aceitemos ou se ela não nos convém. É preciso perseguir a realidade. A realidade é o ponto de partida de toda mudança."

\footnotetext{
${ }^{165}$ Entrevista à revista Teorema-Crítica de Cinema, $\mathrm{n}^{\mathrm{o}} 7$.
} 


\subsection{Formigas treinadas}

No filme 10 on Ten, dez "aulas" sobre o processo de criação dos seus filmes, na última das lições a realidade foi o ponto de chegada. Kiarostami pára o carro ao lado de uma árvore sob o pretexto de mudar a câmera de lugar. Sai do automóvel e a câmera continua ligada mostrando o banco do motorista ausente. Passam-se 30 segundos, tempo suficiente para Kiarostami urinar (ouvimos o som), abrir a porta do passageiro e apanhar a câmera dizendo que antes quer mostrar algo que o fez lembrar um poema japonês ${ }^{166}$. Caminha com a câmera na mão, fora de foco, enquanto recita o poema que fala em “acender o fogo para ver o que os outros não podem ver". Feito o ajuste na lente, mostra o cenário: uma árvore, um pássaro e o chão de terra. Vemos grandes formigas negras que levam comida para dentro de um buraco, num balé que parecia estar só esperando ser flagrado. Exibir a cena em baixa velocidade nos leva a concluir que não há cortes. A "realidade" estava ali esperando por alguém que "acendesse o fogo" para poder enxergá-la.

Em se tratando de Kiarostami podemos gerar a hipótese de que ele parou o carro exatamente ali porque sabia da existência das formigas (a marcação poderia ser muito bem a árvore, onde à direita, abaixo, há um riacho). A não aceitação do acaso se faz por desconfiança de ofício: por que ele teria saído do carro e deixado a câmera ligada? Se era a última lição, por que mudaria a câmera de lugar pela primeira vez? Encontrar

\footnotetext{
166 A propósito, Kiarostami tem o hábito de filmar dentro de carros, como explorou Jean-Claude Bernardet (op. cit.) e esta ação condiz com a verossimilhança de quem está na estrada, sendo natural a parada para urinar, como a que acontece em outro filme seu, E A Vida Continua, com pai e filho. Em 10 on Ten não soa muito elegante, posto que em seguida o diretor recita um haikai filosófico.
} 
formigas na terra é por certo uma possibilidade realista, mas não seria uma encenação para forjar casualidade?

O que Kiarostami parece estar propondo é um realismo sem representação, que vai encontrar em Habermas um fio de estrutura conceitual que pode nos ajudar. Habermas trabalha com duas idéias integradas. Diz ele que, por um lado, o viés pragmático não nos permite duvidar da existência de um mundo percebido independentemente de nossas descrições e visto como o mesmo para todos nós. Por outro lado, não nos é possível sair do círculo da nossa linguagem, de modo que nosso conhecimento falível não pode ter justificações fundamentais.

Se encararmos estes dois aspectos como um processo de conhecimento, ainda segundo Habermas, não existiria separação entre o momento "passivo" de como vemos determinada imagem e do momento "ativo" de construir, interpretar e justificar. "Não há necessidade nem possibilidade de 'limpar' o conhecimento humano dos elementos subjetivos e das mediações intersubjetivas, ou seja, dos interesses práticos e dos matizes de linguagem. Isto não deve conduzir à negação da verdade e da objetividade". ${ }^{167}$

No mesmo raciocínio, Habermas afirma que a verdade de uma sentença só pode ser justificada com a ajuda de outras sentenças já tidas como verdadeiras. O filósofo está falando de verdade e coerência, termos que se imbricam quando o assunto é Kiarostami. Para tanto, lembremos novamente duas seqüências especialmente importantes de Close-up, que melhor simbolizam seu cinema como um todo: a seqüência do julgamento e do encontro de Sabzian com Makhmalbaf. Na primeira, com

\footnotetext{
${ }^{167}$ In: Jürguen HABERMAS, A Ética da Discussão e a Questão da Verdade. p. 57.
} 
aleivosia, Kiarostami inseriu takes do juiz durante conversa do diretor com o réu Sabzian. Fez o público acreditar que o juiz assistiu passivamente Kiarostami "interrogando" o réu, como se tal procedimento fosse comum nos ritos de uma sessão de tribunal. Na segunda, Kiarostami propositalmente cortou o som do diálogo entre Makhmalbaf e o homem que se fez passar por ele. Inventou uma falha técnica para não tornar pública a informação de que Sabzian não queria participar do filme. Portanto, a verdade e a coerência de que fala Habermas fica comprometida em Close-up.

\subsection{Filiais}

Close-up funciona como uma espécie de matriz na filmografia de Kiarostami, pois parece deflagrar uma possibilidade essencial para o diretor: a possibilidade de enganar. Enganar não somente no sentido deste vício de origem do cinema, mas um enganar/mentir em várias camadas, onde as cenas do som e do julgamento são extraordinariamente emblemáticas.

O estilo do cinema de Kiarostami ao longo destes anos tem influenciado uma série de diretores. Como, por exemplo, se examinarmos um certo cinema argentino, tributário do gosto pelo laconismo, pelos longos planos que levam a experiências com o tempo, por estratégias narrativas ligadas mais ao não-dito do que à palavra. No artigo Realismo e histórias mínimas no novo cinema argentino ${ }^{168}$, defendemos justamente esta

\footnotetext{
168 Artigo apresentado no Encontro da SOCINE , Unisinos, São Leopoldo, 2005. Ver MACHADO, Rubens Jr. ...[et al.] (org.). "Realismo e histórias mínimas no novo cinema argentino", Ivonete PINTO. VII Estudos de Cinema - SOCINE. São Paulo: Annablume, 2006, v. VII, pp. 85-92.
} 
conexão com Kiarostami, analisando sobretudo os diretores Raúl Perrone (La Mecha, 2003), e Carlos Sorín (O Cachorro/El Perro, 2004).

Naturalmente, no Irã esta influência é mais imediata e recorrente. Jafar Panahi, Bahman Gobadhi e Hassan Yektapanah, por exemplo, são jovens diretores que inclusive já trabalharam com Kiarostami e são afetados pelo cinema kiarostâmico seja mais no estilo, seja mais na linguagem.

Ainda em solo persa temos outra influência, e desta vez mais categórica. Samira Makhmalbaf, filha do diretor Mohsen Makhmalbaf, oito anos após a realização de Close-up, dirigiu A Maçã (Sib, 1998), onde, com roteiro do pai, reencenou o drama das duas irmãs que viviam trancadas em casa por seus pais. Também em O Quadro Negro (Takhté Siah, 2000), a cineasta procura reconstituir a travessia de curdos entre o Curdistão iraquiano e o iraniano, documentariamente, escamoteando a representação.

Há, nestes dois filmes, A Maçã e O Quadro Negro, um fingimento, uma mentira a priori, a de que a câmera não está ali. E que espécie de real é este em que os personagens são proibidos de olhar para a câmera? No caso de Samira, todo o esforço para parecer realista fica evidente no making of produzido por Maysan Makhmalbaf, filho de Moshen Makhmalbaf e irmão de Samira. ${ }^{169}$

\footnotetext{
${ }^{169}$ Maysan Makhmalbaf, How Samira made the Blackboard (Samira cheghoneh 'Takhté siah' rol sakht). Iran, 2000, 73min. A propósito, Samira, assim como o irmão Maysan,a irmã Hanna e a tia Marziyeh Meshkini (casada com Makhmalbaf depois que este ficou viúvo), também estudou naThe Makhmalbaf Film School. O patriarca Mohsen sustenta que resolveu criar a escola porque nenhum cineasta importante do Irã passou por faculdades de cinema: "Nosso currículo não é limitado ao cinema, ele também inclui partes da vida e da arte. Por exemplo em esportes, ele consiste em ciclismo, natação e skatismo. Um cineasta precisa ser fisicamente forte." (In: MAKHMALBAF, Mohsen, The Day I Became a Woman [roteiro do filme], p. 6-7).
} 
As marcações rígidas, os ensaios com Samira movimentando os curdos como se fossem marionetes, a lama jogada nas roupas para garantir o aspecto de sujos, o "ator" substituído porque não correspondia à performance exigida, são a síntese clara do quanto custa parecer genuíno. O resultado na tela é convincente, o objetivo é alcançado. Mas é o que se pode chamar de real?

Outro iraniano, Amir Naderi, representa mais que uma influência, uma confluência. Autor da sinopse de A Experiência (Tadjrebeh, 1973), de Kiarostami, seus filmes dialogam com Kiarostami em suas experimentações com som.

Naderi, que faz parte deste grupo de cineastas responsáveis pela Nova Onda, movimento que revitalizou o cinema iraniano nos anos 80 , assina filmes à altura de Kiarostami quanto a sua capacidade de instigar, trabalhando a forma de maneira original. A convergência com Kiarostami, embora seus filmes nunca tenham sido exibidos comercialmente no Brasil, é preciso registrar. Se Kiarostami alcança o cume do experimentalismo formal em Five, Naderi não fica atrás com Marathon (2002) e Sound Barrier (2005). O diretor, que desde o final dos anos 90 mora e trabalha nos EUA (filma com baixíssimos orçamentos, diga-se), em Marathon faz um exercício matemático. Na verdade, mistura os sistemas numérico e alfabético aplicando-os às ruas de Nova York onde a personagem Gretchen, uma vez por ano, realiza uma maratona pessoal: tenta completar o máximo possível de palavras cruzadas durante 24 horas, andando na maior parte do tempo nas linhas do metrô de Nova York. Testando seus limites, sua exaustão, a personagem desta maratona lembra o protagonista de O Ciclista, que inspirou Sabzian, com o agravante filosófico de que Gretchen simplesmente não ganhará nada com isto. Enquanto Makhmalbaf opera no registro da causa-efeito, esbarrando no 
melodrama (mostra até a esposa no hospital para não deixar dúvidas de que o ciclista precisava ganhar o dinheiro). Naderi é quase disnarrativo. Não usa diálogos, apenas a voz da mãe da personagem em uma secretária eletrônica, que nos remete ao episódio de Kiarostami em Lumière \& Cia, onde a única voz que ouvimos vem de uma secretária eletrônica. Atraído pela geometria das linhas dos trens, assim como Kiarostami é atraído pelas linhas do mar, das estradas, das árvores, Naderi é adepto também dos buracos negros, do não-dito, dos vazios narativos. Não sabemos qual a motivação de Gretchen, não há relação de causa e efeito. O crítico do Village Voice, Daniel $\mathrm{Ng}$, chegou a afirmar que Marathon, filmado em preto e branco, é um dos filmes mais inventivos desde que Pennebaker realizou o cine-poema Daybreak Express, em 1953. O crítico chama a atenção para o que denomina de "cacofonia orquestrada do som ambiente"170. Em Sound Barrier, Naderi faz uma experiência radical com som, centrada num personagem surdo-mudo. Tal como o idoso de O Coro, de Kiarostami, ao espectador é colocada a mesma impossibilidade do personagem: não ouvir.

Da Inglaterra identificamos uma influência de Close-up: The Road to Guantánamo (2006), dos diretores britânicos Michael Winterbottom e Mat Whitecross. Trata-se da repercussão do ataque de 11 de setembro de 2001 às torres gêmeas de Nova York e a prisão em Guantánamo dos suspeitos do atentado. O filme traça a história de quatro muçulmanos ingleses que viajaram ao Paquistão, como convidados de um casamento, e que acabaram mandados para a prisão americana em território cubano como suspeitos de terrorismo. Não é um documentário, mas sim a reencenação destes fatos e a referência a Close-up não foi ignorada pelo crítico do The New York Times, A. O. Scott, que somou ao filme ainda mais dois títulos:

\footnotetext{
${ }^{170}$ Daniel NG, Noises Off: Seeking Solace in the Ambient Sounds of the City. In: Village Voice, http://www.villagevoice.com/film/0413,ng,52198,20.html
} 
(...) O filme não está sozinho ao situar-se nesta fronteira entre ficção e documentário. The Road to Guantánamo parece ter sido inspirado ao menos parcialmente por filmes iranianos como Close-Up, A Maçã e Onde Fica a Casa do Meu Amigo?, os quais utilizaram pessoas comuns e locações para recriar acontecimentos reais. ${ }^{171}$

\subsection{Imagens transgênicas}

Não fosse a conotação porventura condenatória, se poderia afirmar que estes diretores, matriz (Kiarostami) e filiais, produzem imagens transgênicas. Artificialmente transferem genes de um real produzindo um outro organismo de real. Naturalmente, a associação com a transgenia soa - ou pode soar - negativa e desproposital de antemão, já que a transgenia está ligada à saúde e, por sua vez, a manipulação de fatos para chegar a uma dada realidade (do cinema, do cineasta) está ligada aos valores do homem. As alusões e referências podem ser várias, porém a idéia é, tão somente, retirar da obra de Kiarostami (e seus discípulos) um véu diáfano de representante de um ideal de verdade. Ou melhor, é sugerir que o véu que cobre seus filmes encobre movimentos arquitetados.

Seria possível defender que, em razão das fronteiras entre o que é ficção e o que é não-ficção serem tênues demais, não havendo a chance de uma representação objetiva do real, o filme documentário sequer existiria de fato. ${ }^{172}$

\footnotetext{
${ }^{171}$ In: "The Road to Guantánamo Offers Grim Chronicles That Anger and Stir", The New York Times [online] http://movies2.nytimes.com/2006/06/23/movies/23guan.html?th\&emc=th

${ }^{172}$ Esta hipótese, naturalmente, contraria Bill Nichols, que pensa num sentido lato senso. Ele afirma que "Todo filme é documentário. Mesmo a mais extravagante das ficçõoes evidencia a cultura que a produziu...". In: Bill NICHOLS, Introdução ao Documentário, op. cit., p. 26
} 
A complexidade, somada à natureza provocativa deste tema, culminou em projetos experimentais que se prestavam a avançar no problema. Em diversas oportunidades, câmeras digitais fixas foram deixadas captando imagens 24 horas, ininterruptamente. Estas imagens revelariam a verdade daquele lugar? Não houve manipulação de um diretor, nem cortes de um editor, no entanto, ao escolher fixar a câmera em um ponto específico, já há uma escolha. Ligar uma câmera numa rua $\mathrm{X} \mathrm{e}$ determinar que o enquadramento deixe de fora prédios de um dos lados desta rua, por exemplo, seria uma forma de edição, que por sua vez, revelaria uma decupagem, uma formulação, um recorte, uma tese, uma construção que não é mais a realidade daquela rua, com prédios à direita e à esquerda. É (seria) ficção.

A tentativa dos cineastas que perseguem a objetividade/captação absoluta do real beira o desespero. Tanto quanto a tentativa dos ascetas de tradição bramânica na Índia, os jainistas, que no dever de nunca prejudicar qualquer ser vivo, usam máscaras para evitar que, involuntariamente, matem micro insetos pela aspiração.

Parece-nos razoável supor, então, que não há saída frente à impossibilidade da existência do real mediado por uma câmera. Esta questão, per si, seria estéril e sua discussão, pífia, não fosse encerrar um conteúdo ético. E “a ética é uma espécie de irmã siamesa da estética”, como bem disse Evaldo Mocarzel $^{173}$, o que justificaria introduzi-la nesta análise, já que estamos tratando de juízos de valor no universo fílmico. É, pois, legítimo perguntar por que mostrar isto, em detrimento daquilo, a um cineasta que se apresenta como alguém preocupado em revelar a verdade e que submete sua obra ao julgamento do público e da crítica sob esta perspectiva. Por fim, é congruente analisá-lo

\footnotetext{
${ }^{173}$ Evaldo MOCARZEL, “A Palavra no Documentário”, Revista Cinemais - Especial: Documentário. № 36, out-dez, 2003, p. 73.
} 
sob a perspectiva da ética porque este é um problema que se impõe nos próprios filmes de Kiarostami: o menino que quer devolver um caderno que não é seu, passando por personagens que se negam a participar de um ato moralmente condenado pela religião, que é o ato suicida, um garoto que mente para conseguir ir a um jogo de futebol, um homem que se faz passar por outro.

\subsection{Close for Fake}

Neste momento nos parece oportuno fazer uma aproximação com o filme que mais radicalmente tocou na questão da verdade e da mentira, extrapolando inclusive a dimensão do cinema. Trata-se de F for Fake - Verdade e Mentiras, de Orson Welles. Welles, que adiante aparecerá mais uma vez relacionado a Kiarostami quanto à modernidade, é trazido diretamente pelo próprio Sabzian, que no documentário Closeup Long Shot, afirma: Eu penso em Orson Welles quando ele dava conselhos aos estudantes que perguntavam como era possivel conseguir dinheiro para fazer um filme, Welles respondia: roube!

Em $F$ for Fake, o diretor americano trabalha com outra transgressão, a mesma de Kiarostami, a mentira. Neste filme, Welles realizou a obra cinematográfica mais provocativa de todos os tempos sobre o fakery. Fez um falso documentário sobre um húngaro chamado Elmyr de Hory, um falsificador de pinturas que reproduziu entre outros pintores, Matisse. Elmyr, por sua vez, tem sua história contada pelo escritor Clifford Irving, autor de uma falsa biografia sobre Howard Hughs. Welles usa imagens de um documentário da BBC e de François Reichenbach, seu próprio diretor de fotografia, que possuía uma entrevista com Elmyr, pois pretendia fazer um 
documentário sobre o famoso falsário. Com este material, somado às suas próprias intervenções como narrador e a participação de personagens fictícios, Welles vai tecendo um emaranhado de nós difícil de desembaraçar. Neste emaranhado, é importante não esquecer que Welles é autor do célebre programa A Guerra dos Mundos, a leitura radiofônica sobre invasão de marcianos que o público tomou por verdadeira. ${ }^{174}$

$\mathrm{Na}$ analogia que nos propomos fazer, num primeiro momento temos claro que Sabzian equivale a Elmyr de Hory. Um falsificador. Num segundo momento, porém, esta analogia recai mais fortemente sobre Orson Welles e Kiarostami. A diferença é que Welles apresenta-se no filme como um mágico, como um artista interessado na trucagem, na farsa. Intitulando-se um mágico logo na abertura do filme, Welles dota seu discurso de uma honestidade inegável. Por mais intrincado e cheio de falsas informações que seja $F$ for Fake, Welles não finge enfrentar problemas técnicos para ratificar a natureza documental de suas imagens. Ao contrário, mesmo que afirme no começo do filme que o tema gira em torno da mentira, mas que na próxima hora o espectador vai ver somente a verdade, Welles introduz esta fala com a saudação típica de apresentadores de circo e mágicos: ladies and gentleman! É com o "senhoras e senhores!" na impostação circense que o espectador é convidado a entrar no universo do espetáculo e não do jornalismo. Neste sentido, Kiarostami foi mais além do que Welles no que diz respeito à farsa. No início de Close-up ele não afirma em tom farsesco que tudo o que será visto é verdade, ele usa a materialidade da rotativa, símbolo do jornalismo e, por extensão, da verdade, para fazê-lo.

\footnotetext{
${ }^{174}$ Em "A Guerra dos Mundos", Orson Welles narrou o começo da novela de H. G. Welles em que marcianos invadiam a terra, utilizando o formato de noticiário. O grau de veracidade da dramatização levou milhares de ouvintes ao pânico. De certa forma, todos os documentários citados nesta tese, que enganam o espectador com habilidade, pagam tributo a este programa.
} 
Orson Welles, como narrador, quase ao final do filme vira o jogo: Prometemos que por uma hora falaríamos apenas a verdade. Esta hora, senhoras e senhores, acabou-se. Pelos últimos 17 minutos eu estive mentindo sem parar. A verdade, e por favor perdoe-nos por isso, é esta, nós forjamos uma história sobre arte. Como um charlatão, meu trabalho foi fazê-la parecer real.

Para quem percebeu que o corte do som no encontro de Sabzian com Makhmalbaf era falso, a atitude de Kiarostami equivale a esta virada em $F$ for Fake. Kiarostami parece dizer: "tudo o que vocês viram era ficção, havia uma mise-en-scène, uma encenação do drama. Somente nos últimos minutos, em que o som falhou, vocês tiveram a verdade sem edição”. O problema é que este - como o julgamento - é o principal momento de falsificação, só que tão bem feita, inclusive porque perpetratada pela própria intervenção do diretor, que não foi percebida. E este é o nó Górdio da história de Elmyr de Hory: ele foi um falsificador de quadros tão excepcional que enganou diretores de museus e toda sorte de experts. E o que Kiarostami fez com o corte do som foi justamente conseguir enganar experts como Jean-Claude Bernardet e Tata Amaral. Kiarostami está mais para Elmyr de Hory ou para Orson Welles?

\section{1 - A mentira no Oriente e no islamismo}

Como Kiarostami e Sabzian situam-se quanto à mentira no Corão.

Como a maioria das religiões, o islamismo proibe a mentira. O Corão, na sura 40:28, traz:

E um homem crente, da família de Faraó, o qual ocultava sua fé, disse: 'Meu senhor é Allah, enquanto, com efeito, vos chegou com as evidências de vosso Senhor? E, se ele 
é mentiroso, em seu prejuízo será uma mentira. E, se é verídico, alcançarvos-á algo do que ele vos promete. Por certo, Allah não guia quem é entregue a excessos, mentiroso! ${ }^{175}$

$\mathrm{Na}$ sura 24:11, Alá avisa que os que mentem são muitos entre os homens e todos eles receberão o que merecem.

Na política de um país regido pela sharia, como o Irã, paradoxalmente vamos encontrar uma certa flexibilidade quanto a esta questão. Como se a mentira fosse justificada em situações onde ela seria necessária.

O presidente iraniano Mahmoud Ahmadinejad, ao negar a existência do holocausto, ou chamá-lo de mistificação, está empenhado em valorizar a causa palestina e contestar o direito de Israel sobre o território árabe. E ao negar que esteja produzindo energia nuclear para fins bélicos, o presidente apenas quer garantir o direito de fazer pesquisa e usar a energia nuclear para fins pacíficos.

A mentira, digamos, tolerada porque com propósitos islamicamente defensáveis (como a prática da taqiya, citada anteriormente), pode ser encontrada na sura 16:106, que aceita o fato de um fiel ter sido seqüestrado e forçado a renegar sua fé. O próprio Maomé teria dito ao fiel que se fosse compelido novamente, ele poderia renegar Allah e seria perdoado.

No hadith que fala na união dos muçulmanos, mais uma vez Maomé enfatiza a idéia de mentiras que podem ser aceitas. Ele diz, por exemplo, que os fiéis não devem

\footnotetext{
${ }^{175}$ In: Tradução do Sentido Nobre do Corão para a Língua Portuguesa, op cit., p.775
} 
ser responsabilizados por suas mentiras, exceto quando em guerras, para promover a reconciliação entre marido e mulher e para ajudar na reconciliação entre muçulmanos.

Considerando que Kiarostami teve uma atitude política ao falar sobre as razões que o levaram a cortar o som do diálogo entre Sabzian e Makhmalbaf, ele igualmente flexibilizou sua mentira. Disse que cortou o som para não expor Sabzian, que não sabia, segundo ele, estar sendo gravado. Digamos, então, que mentiu para o bem do filme e, por extensão, dele, Kiarostami. Em outras palavras, mentiu para promover a reconciliação entre dois muçulmanos, ele e Sabzian, estando desse modo em conformidade com o hadith de Maomé. Ainda assim, esta relação não é exatamente bidimensional. $\mathrm{O}$ espectador também foi submetido à atitude de Kiarostami. O que faz a diferença, gerando outro peso e outra medida, é a mediação da arte. Pois se entre Kiarostami e Sabzian existe o aparato do cinema (a câmera), entre Kiarostami e o espectador do filme há o dispositivo do cinema, no sentido dado por Baudry e Metz (o estado psíquico particular que caracteriza o espectador de cinema durante a projeção) ${ }^{176}$.

Esta relação tridimensional nos leva a outras conotações em termos de artefíctio, ou artifício, como veremos a seguir.

\footnotetext{
${ }^{176}$ Para mais detalhes ver Christian METZ, Le Signifiant Imaginaire: psychanalyse et cinema e JeanLouis BAUDRY, "Le Dispositif: Approches métapsychologiques del'impression de réalité".
} 


\section{2 - A mentira na filosofia (ocidental)}

$O$ "dever da verdade" em Rousseau, Benjamin Constant e Kant. O persa Mani influencia Santo Agostinho, que dá subsídios a Derrida, que levanta hipóteses para compreendermos a mentira no persa Kiarostami. 
Verdadeiro e falso são conceitos que, grosso modo, vinculam-se a uma correspondência ou não com a realidade. A interpretação aprofundada destes conceitos obrigatoriamente nos leva aos gregos, pois como diz Jean-Claude Bernardet a respeito de uma maçã que rola em $O$ Vento nos Levará: “...a verdade não é da ordem do realismo, das aparências, do cotidiano, dos fatos. É sim uma questão filosófica."177

Em A Odem do Discurso, Michel Foucault lembra que na Grécia do século VI, o discurso verdadeiro, que era respeitado e temido, era o discurso que falava da justiça, numa espécie de ritual de enunciação: profetizava o futuro, contribuindo assim para o que iria acontecer. Mais tarde, à verdade do discurso importava não o que ele era capaz de fazer, mas o que era capaz de dizer. Foucault defende que existe uma "partilha" entre o verdadeiro e o falso e uma vontade de verdade que atravessou os séculos.

Embora não use a expressão "vontade de verdade”, Carlo Ginzburg, em Olhos de Madeira, interessou-se pelo tema, trazendo os conceitos que o circundam (o falso e o verossímel), como nesta resposta de Sócrates: “A Fedro, que lhe pergunta se o mito de Bóreas e Orítia é 'verdadeiro', Sócrates responde que a exegese 'rústica' da alegoria pode chegar no máximo a uma conclusão verossímil."178

Ginzburg também recupera o que escreveu Isidoro de Sevilla sobre o falso: "é o que não é verdadeiro, 'ficto' (fictum), o que é verossímel."179 Já Platão, segundo Ginzburg, interessava-se por discutir não o mito em si, enquanto discurso, mas

${ }^{177}$ In: Caminhos de Kiarostami, op. cit. 87.

${ }^{178}$ In: Carlo GINZBURG, Olhos de Madeira, , cap. 2 Mito - Distância e mentira, p. 45. Não custa lembrar, que Aristóteles na Poética fundou o pensamento sobre verossimilhança utilizado pela dramaturgia, onde o verossímil é o que tem o aspecto da verdade, o que é provável.

${ }^{179}$ Idem, p. 57. 
procurava distinguir, no interior dos mitos transmitidos pela tradição, o verdadeiro do falso.

Ginzburg aprofunda:

$\mathrm{Na}$ nossa tradição intelectual a consciência da natureza mentirosa dos mitos, e, por extensão, da poesia, acompanhou como uma sombra a persuasão da sua verdade oculta. A fictio, na sua acepção positiva e construtiva, proporcionou uma saída para as duas alternativas, insustentáveis num plano literal, da poesia como verdade e da poesia como mentira. ${ }^{10}$

Ginsburg parece dizer que a "fictio", a raiz latina de ficção, é uma saída honrada para o problema sobre a verdade e a mentira. No entanto, a "fictio" nada mais é do que seu parônimo, também latino, o "facticio", aquilo que é produzido artificialmente. Por sinal a definição lexical de facticio nos ajuda a refletir:

O que, distanciando-se do natural, adquire pela mão do homem a qualidade do artístico, se converte em factício. Assim a facticidade tende a ser essa condição dos objetos de predominância artificial que, seja porque contêm em si mesmos qualidades para converterem-se em artístico, ou seja porque a artificialidade as confere, reúnem condições para ser considerados arte. (...) Podemos considerar a facticidade como a pronunciada tendência de alguns objetos ou ações a converterem-se em artísticos mediante a manipulação dos meios naturais, os elementos naturais, as condições e estados naturais, até poder considerá-los em uma alta proporção como artificiais. $^{181}$

Se os conceitos soam como por demais abstratos, o controle deles, ao menos para Ginzburg, tem conseqüências mais concretas do que podemos imaginar. Para Ginzburg, a elaboração do "fictio" tem implicações com o patrimônio tecnológico "que

\footnotetext{
${ }^{180}$ Idem, p. 56.
} 
conferiu aos europeus a possibilidade de conquistar o mundo" ${ }^{182}$, aliando-se a isto "a capacidade, acumulada no curso dos séculos, de controlar a relação entre visível e invisível, entre realidade e ficção." 183

Esta sinalização de Ginzburg para o campo da economia, de certo modo nos interessa, afinal, o Irã é um país que investe no cinema (mais de $90 \%$ da produção é subsidiada pela Fundação Farabi, do governo), pois politicamente tem consciência, principalmente desde Khomeini, do poder do cinema no imaginário dos povos. Mas para não nos afastarmos do foco desta análise, convém que retornemos à filosofia e suas implicações com a ética do fazer cinema.

Como já afirmamos, existiria no cinema um direito à invenção, indissociável à sétima arte, ou pelo menos, à ficção. Milan Kundera já disse que a ficção é um terreno em que os julgamento morais são suspensos. Mas, considerando que mesmo no plano da invenção, do artifício "lícito", o cineasta em questão joga com o discurso da verdade, nos perguntamos: seria uma obrigação relativa dizer a verdade no plano fílmico e extrafílmico?

Esta idéia de "obrigação relativa", que dialoga com as suras do Corão e os hadith de Maomé recém citados, é o principal tema de Jean-Jacques Rousseau, Immanuel Kant e Benjamin Constant em Os Filósofos e a Mentira, uma seleção de textos organizada por Fernando Puente. Rousseau, de fato, é quem defende a relatividade do dever de dizer a verdade sempre. O filósofo suiço defendia que o dever

\footnotetext{
${ }^{181}$ Diccionario de la Lengua Española - Real Academia Española (DRAE), edición en CD-ROM (22 ed.) - ESPASA-CALPE, S.A., Madrid, 2003.

${ }_{182}^{182}$ Idem, p. 57.

${ }^{183}$ Idem, idem.
} 
de dizer a verdade era somente em relação a certas pessoas. Para isto, usou o exemplo de um sujeito que, perguntado por um ladrão se ele tinha dinheiro, mentiu respondendo que não. No texto, Rousseau também assegura que a verdade está ligada a uma questão de justiça: “(...)se é um fato inútil, indiferente em todos os aspectos e sem conseqüências para ninguém seja verdadeiro ou falso, isso não interessa a ninguém." 184

Então, cabe perguntar: levando-se em conta que Kiarostami mentiu criando a conversa com os técnicos para forjar a falha no som e mentiu em entrevistas sobre a motivação de ter cortado o som, a quem estas mentiras prejudicam? A Sabzian, a Makhmalbaf, ao público? Supondo que não existam prejudicados, é Rousseau quem responde com outra pergunta: "Se não causo nenhum dano a outrem enganando-o, disso resulta que não o causo de nenhum modo a mim mesmo, e basta jamais ser injusto para ser sempre inocente?"185

Nessa discussão, o suiço-francês Benjamin Constant contribui ao atestar que dizer a verdade é um princípio moral, mas que tornaria impossível toda a sociedade:

Temos a prova disso nas conseqüências muito diretas que um filósofo alemão tirou desse princípio, chegando até mesmo a pretender que a mentira fosse um crime em relação a assassinos que vos perguntassem se o vosso amigo, perseguido por eles, não está refugiado em vossa casa. $^{186}$

Kant entra no diálogo multiplicando a sinuosidade do assunto. Para ele, contradizendo o que Constant afirmou sobre a verdade ser um dever em relação àquele

\footnotetext{
${ }^{184}$ In: Fernando Rey PUENTE (org), Os Filósofos e a Mentira, "Devaneios do passeante solitário", JeanJacques ROUSSEAU, p. 38.

${ }^{185}$ Idem, p. 40.
} 
que tem um direito à verdade, a expressão "ter um direito à verdade" é sem sentido. Seria preciso dizer:

$O$ homem tem um direito à sua própria veracidade (veracitas). (...)A veracidade nas declarações que não se pode evitar é dever formal do homem em relação a cada um, por maior que possa ser o dano dai resultante para ele ou para um outro (...) $)^{187}$

Segundo o alemão Kant, a veracidade, um imperativo categórico, "é um mandamento sagrado da razão, um mandamento condicional, não restringido por conveniência ou circunstância alguma, e que a mentira corrompe na raiz todas as coisas humanas $(\ldots){ }^{\prime \prime}{ }^{188}$

Não podemos esquecer que Close-up só existe em função de uma mentira: a que Sabzian sustenta para a família Ahankhah. Porém, neste capítulo, nosso questionamento não atinge Sabzian porque não nos interessa a sua mentira, mais afeita ao campo do Direito. Especificamente aqui, interessa-nos o campo da ética: como Kiarostami conta os fatos envolvendo Sabzian. Para tanto, a situação filosófica que Close-up apresenta durante a cena do julgamento de Sabzian, no nosso entender, é a que mais provoca reflexão.

Um dos filhos dos Ahankhah, Mehrdad, diz para o juiz: "Ele entrou na nossa casa para nos roubar". Sabzian defende-se: "Eu só queria ser convincente, não queria roubar". A partir de conceitos de Alain Badiou em El Cinema como experiência

\footnotetext{
${ }^{186}$ Idem, "Das relações políticas", Benjamin CONSTANT, p. 69. Quanto ao "filósofo alemão", grifo nosso, segundo Renato Janine RIBEIRO no artigo "Filósofos examinam o direito de mentir", Constant referia-se a Kant (Folha de São Paulo, 9 ago., 2003).

${ }^{187} \mathrm{Idem}$, "Sobre um pretenso direito de mentir por amor aos homens", Immanuel Kant, p. 75-76.

${ }^{188}$ Idem, "Nota dos tradutores", p. 78.
} 
filosófica ${ }^{189}$, podemos afirmar que esta é uma clara situação filosófica porque temos que decidir se acreditamos nas palavras de Mehrdad Ahankhah ou nas de Hussein Sabzian.

A filosofia consiste, para Badiou, em classificar uma escolha, uma decisão, e em esclarecer a distância entre o poder e as verdades. Consiste também em estabelecer o valor de ruptura (contra quem Sabzian se insurge?). Deleuze, segundo Badiou, chamava estas relações (sujeito e poder - aqui: Sabzian e o Estado) de "síntese disjuntiva". Ou seja, "uma relação que não é uma relação, uma relação paradoxal, uma ruptura. E há filosofia cada vez que se quer pensar uma relação deste tipo."190

\subsection{História da mentira}

Jacques Derrida escreve que, se existe uma história da mentira, isto é, uma história do falso testemunho, ela não poderia se deixar apropriar por uma história do erro ou da verdade. Por outro lado, lembra Derrida, se a mentira supõe a invenção deliberada de uma ficção, nem toda ficção ou fábula equivale a uma mentira; tampouco a literatura.

Pode-se, desde já, imaginar mil e uma histórias fictícias da mentira, mil e um discursos inventivos, fadados ao simulacro, à fábula, à produção de formas novas referentes à mentira e que nem por isso sejam histórias mentirosas, isto é, se adotarmos o conceito clássico e

\footnotetext{
${ }^{189}$ In: Gerardo YOEL (org.), Pensar el cine, 1 - Imagem Ética e Filosofia, Cf. Alain BADIOU no artigo "El Cinema como experiência filosófica".

${ }^{190}$ Idem, p. 28.
} 
dominante da mentira, histórias que não sejam perjúrios e falsos testemunhos. ${ }^{191}$

Derrida nos conta em História da mentira: prolegômenos ${ }^{192}$, como se aproximou do tema através de Nietzsche e seu texto "História de um Erro", onde ele, Nietzsche, desenvolve a idéia de como o mundo verdadeiro acaba se tornando uma fábula. Para Nietzsche, segundo o filósofo argelino-francês, "nessa inspirada fábula sobre uma afabulação, a verdade, a idéia de um mundo verdadeiro seria um erro"193. Derrida, contudo, acrescenta: “Em princípio, porém, e em sua determinação clássica, a mentira não é o erro. Pode-se estar no erro, enganar a si mesmo sem intenção de enganar os outros e, portanto, sem mentir."194.

Derrida atenta para o termo pseudos, em grego, que pode significar a mentira tanto quanto a falsidade, o ardil ou o erro, o engano propositado, a fraude, assim como a invenção poética. Estas possibilidades multiplicariam os mal-entendidos sobre o que o mal-entendido pode significar. "Mentir não é enganar-se nem cometer erro; não se mente dizendo apenas o falso, pelo menos se é de boa fé que se crê na verdade daquilo que se pensa ou daquilo acerca do que se opina no momento" 195 .

Santo Agostinho, nascido, como Derrida, no que hoje é território argelino, escreveu o célebre De Mendacio (A Mentira), onde propõe uma distinção entre crença

\footnotetext{
${ }^{191}$ In: Jacques DERRIDA, História da mentira: prolegômenos. [online]. maio/ago. 1996, vol.10, no.27, p.7-39. Disponível no site http://www.scielo.br/scielo.php?script=sci_arttext\&pid=S0103-

$40141996000200002 \& \operatorname{lng}=\mathrm{es} \& \mathrm{nrm}=$ iso

${ }^{192}$ Idem (documento on line $[\mathrm{s} / \mathrm{p}$.$] )$

${ }^{193}$ Idem.

${ }^{194}$ Idem.

${ }^{195}$ Idem.
} 
e opinião ${ }^{196}$. Conforme ele, mentir é querer enganar o outro, às vezes até dizendo a verdade. Pode-se dizer o falso sem mentir, mas pode-se dizer o verdadeiro no intuito de enganar, ou seja, mentindo.

Por um certo tempo simpatizante do maniqueísmo, doutrina criada pelo persa Mani $^{197}$, Santo Agostinho, antes de se aprofundar nos Evangelhos, acreditava nas dualidades. Embora o termo "maniqueísmo" ou "maniqueísta" é entendido contemporaneamente de forma depreciativa, como doutrina filosófica mostra-se defensável, sobretudo pelo seu caráter ecumêmico (propunha a união de todas as grandes religiões da Antigüidade, como o cristianismo e o zoroastrismo). A idéia central é de que o binômio luz e trevas habita cada ser vivo.

Ora, uma aproximação com a filosofia da dualidade contida na obra de Kiarostami é legítima, como estamos vendo até agora, e dialoga com as reflexões sobre a verdade versus mentira, ficção versus não-ficção que estamos tentando desenvolver aqui. Então, voltando a Derrida. Quando cita Agostinho, Derrida critica-o por excluir a mentira a si mesmo (“Quem enuncia um fato que lhe parece digno de crença ou acerca do qual formava opinião de que é verdadeiro, não mente, mesmo que o fato seja falso"). E faz uma pergunta a que ele não tem resposta: "será que é possível mentir a si mesmo, será que qualquer forma de enganar a si mesmo, de usar de subterfúgio para consigo merece o nome de mentira?" 198

\footnotetext{
${ }^{196}$ Santo Agostinho, "Le mensonge (De mendacio)", Primeira parte, $1^{\mathrm{a}}$ seção, 111, 3, trad. fr. G. Combes, em Oeuvres de Saint Augustin, Paris, 1937-1948, T. 2, p. 237. Citado por Jacques DERRIDA, Idem.

${ }^{197}$ Mani,ou Manes, viveu entre 210 e 276 d.C.

${ }^{198}$ In: Jacques DERRIDA, op. cit.
} 
Desenredando-se desta teia agostiniana, Derrida passeia por vários outros autores. Ao buscar reforço teórico em Hannah Arendt, entra no campo de análise da mentira (e da verdade) na política. Para a filósofa alemã, segundo Derrida, o mentiroso é um homem de ação por excelência. Entre mentir e agir, agir em política, manifestar a própria liberdade pela ação, transformar os fatos e antecipar o futuro haveria como que uma afinidade essencial.

A intenção não é sugerir que os procedimentos de Kiarostami sejam de ordem política, mas tirar partido do pensamento de Arendt, pois é ela quem introduz na reflexão um elemento caro à produção de Kiarostami, que é a imaginação. Para ela, a imaginação é a raiz comum à "capacidade de mentir e à capacidade de agir". ${ }^{199}$

Capacidade da imagem em produzir: imaginação produtora como experiência do tempo, teriam dito Kant ou Hegel. (...) é claro que não temos apenas aqui, esclarecida por Hannah Arendt, a idéia de uma história da mentira, mas, também, com radicalidade maior, a tese segundo a qual não existiria história em geral nem história política em particular sem ao menos a possibilidade do mentir, isto é, da liberdade e da ação. Assim como a da imaginação e a do tempo, da imaginação tanto quanto do tempo. ${ }^{200}$

Ignácio Gomes de Liaño, em seu La Mentira Social, também cita Arendt quanto ao papel da imaginação na história da mentira, mas toma como ponto de partida o método mnemônico de Giordano Bruno, o filósofo do Renascimento. Liaño lembra que Giordano Bruno pretendia, com o método, moldar a mente mediante uma reestruturação

\footnotetext{
${ }^{199} \mathrm{O}$ texto de Arendt a que Derrida cita é "Truth and politics, tr. fr. Vérité et politique, por Cl. Dupont e A. Hurant, em La Crise de la Culture, Idées Gallimard, 1972”. In: Jacques DERRIDA, Idem. ${ }^{200}$ Idem
} 
dos conteúdos imaginários, ou seja, mediante refinados exercícios de imaginação, onde a memória não existiria em si, mas como resultado de lembranças inventadas.

Liaño trabalha com conceitos de imaginação, imagem, simulacro e suas conexões com memória, tempo e verdade no contexto da filosofia. Utiliza Hegel para afirmar que a história da filosofia havia sido “ 'um álbum de imagens', uma série de evoluções ideais em torno dos conceitos de memória e imagem."201 A Mentira Social do filósofo espanhol busca parentesco com A Mentira em Política, texto de Hannah Arendt referido por Derrida, na seguinte citação:

A deliberada negação da verdade fática - a capacidade de mentir - e a capacidade de mudar os fatos - a capacidade de atuar - se encontram interconectadas. Devem sua existência a uma mesma fonte: a imaginação. ${ }^{202}$

Ainda lançando mão do pensamento de Hannah Arendt, Liaño recorda que as mentiras resultam às vezes muito mais plausíveis e mais atrativas à razão, que à realidade, pois quem mente tem uma grande vantagem de conhecer de antemão o que sua audiência deseja e espera ouvir.

$\mathrm{O}$ vínculo imediato que se pode fazer com Kiarostami diz respeito à recepção de sua obra. O público do cinema iraniano, e de Kiarostami em especial, espera determinado procedimento formal (ritmo lento, não-linearidade, silêncios estratégicos, longos planos-seqüência) e espera um tratamento realístico às imagens. É uma espécie de contrato que se estabelece, ao menos com o público iniciado. Neste sentido, o

\footnotetext{
${ }^{201}$ In: Ignácio Gómez de LIAÑO, La Mentira Social-Imagens, Mitos y Conducta, op. cit., p. 10.

${ }^{202}$ Idem, apud Arendt, p. 11.
} 
espectador espera que Sabzian não atue para a câmera, mas que seja ele mesmo. Espera que o diretor diga a verdade não importa a que preço. Ora, não existiria prova maior de sua honestidade para com as expectativas do público, que manter na montagem um defeito técnico do filme. O corte do som, assim, é uma mentira que quer comprovar uma verdade.

Tão importante como o star system para Hollywood, o real é a estrela para os filmes de Kiarostami, mesmo para as experiências mais poéticas e ensaísticas, como Five. Ou, poderia-se dizer, sobretudo em Five, onde o jogo com a platéia se estabelece a partir da câmera fixa, no plano-seqüência, onde a natureza é mostrada "sem intervenção", como vimos anteriormente.

Como balanço deste capítulo, só nos resta perguntar: no plano da ética, até onde pode ir um diretor?

\section{3 - Kiarostami religioso e grego}

Mimesis, de Aurbach, novamente nos ilumina o caminho para compreender Close-up. Agora quanto à verdade e as relações que podemos fazer com Homero e o texto bíblico a partir da interpretação de Auerbach. 
Auerbach faz a distinção sobre a verdade na Odisséia (um relato histórico) e a verdade no relato sobre o sacrifício de Isaac e a provação a que Abraão foi submetido (um relato bíblico). Ambas narrativas, conforme Auerbach, são histórias lendárias, "porém, a intenção religiosa condiciona uma exigência absoluta de verdade histórica". 203

O narrador biblico tinha que acreditar na verdade objetiva da história da oferenda de Abraão - a a persistência das ordens sagradas da vida repousava na verdade desta história e de outros semelhantes. Tinha de acreditar apaixonadamente - ou então, deveria ser, como alguns exegetas iluministas admitiram ou, talvez, ainda admitem, um mentiroso consciente, não um mentiroso inofensivo como Homero, que mentia para agradar, mas um mentiroso político consciente das suas metas, que mentia no interesse de uma pretensão à autoridade absoluta. ${ }^{204}$

Auerbach chama esta hipótese iluminista de absurda (a que considera o relato bíblico uma mentira consciente), pois o relato bíblico tinha que descrever exatamente aquilo que fosse exigido "por sua fé na verdade da tradição, ou, do ponto de vista racionalista, por seu interesse na sua verossimilhança - seja como for, a sua fantasia inventiva ou descritiva estava estreitamente delimitada"205.

O que o texto bíblico produzia não visava de imediato a "realidade", isto poderia ser um meio, mas não um fim. O objetivo era atingir "a verdade". Para Auerbach, quem não acredita na história de Abraão não pode fazer do relato bíblico o uso para o qual foi destinado.

\footnotetext{
${ }^{203}$ In: Erich AUERBACH, Mimesis, op. cit.p. 11

${ }^{204}$ Idem, ibidem. (grifos nossos)

${ }^{205}$ Idem, ibidem.
} 
A pretensão de verdade da Bíblia é não só muito mais urgente que a de Homero, mas chega a ser tirânica; exclui qualquer outra pretensão. O mundo dos relatos das Sagradas Escrituras não se contenta com a pretensão de ser uma realidade historicamente verdadeira - pretende ser o único mundo verdadeiro, destinado ao domínio exclusivo. ${ }^{206}$

Já Homero, na visão de Auerbach, quer tão somente agradar ao seu leitor, não está a serviço de uma doutrina religiosa.

Pois bem, mais uma vez, parece-nos que Kiarostami está entre uma situação e outra. Por um lado, ele é o autor "religioso" que objetiva trazer à luz um acontecimento e que não mede esforços para mostrar-se verdadeiro (a rotativa, a falha do som, a atitude de não entrar na casa da família Ahankhah quando no tempo cronológico dos fatos ele não poderia ter estado lá). Kiarostami segue uma doutrina própria onde existe um discurso enaltecedor da verdade e existe, ligada à questão da verdade, o aspecto da justiça que ele defende (Kiarostami não queria prejudicar Sabzian, que não tinha microfone e não sabia que estava sendo filmado). Haveria, portanto, um caráter de sagrado neste comportamento, que filiaria Kiarostami nesta perspectiva bíblica a que se debruça Auerbach.

Por outro lado, Kiarostami também é Homero querendo agradar seus leitores/espectadores. Como o grego, Kiarostami, procurou um efeito seja no julgamento, buscando arrancar de Sabzian respostas cujas perguntas o juiz não faria - e Kiarostami as fez, como se juiz fosse -, seja no corte do som, empenhando-se em subtrair do público as inquietações de Sabzian sobre o projeto do filme.

${ }^{206}$ Idem, ibidem. 


\subsection{Os gregos e a falsafa}

É oportuno chamar a atenção, a propósito do contexto da reflexão de Auerbach (Bíblia e Grécia Antiga), que mesmo Kiarostami sendo muçulmano, a investigação sobre sua obra pode valer-se de fontes bíblicas, já que o islamismo é uma das três grandes religiões reveladas e toda sua história pertence ao Antigo Testamento. E, de resto, toda associação com os gregos é legítima, na medida em que foram os muçulmanos que traduziram os filósofos gregos para o árabe e para o persa agregando, inclusive, dimensões do universo islâmico, como veremos.

A influência grega no universo muçulmano é um fato. Muito antes da conquista pelos árabes, desde o final do século III, havia comunidades gregas importantes no Irã. Isto porque Alexandre, o Grande, tomou Persépolis colocando fogo nos palácios e para dominar os persas de forma completa, casou com a filha do rei Dario, determinando também o casamento de 90 gregos com 90 mulheres persas. A unificação se completaria com a fusão dos exércitos: 30 mil persas foram integrados no exército de Alexandre com as mesmas patentes dos gregos. ${ }^{207}$

Com o passar do tempo foram surgindo grupos socioculturais, que não eram compostos somente por comeciantes ou ricos proprietários, mas também por teólogos, filósofos e sábios, que por sua vez trabalhavam com a filosofia grega: "A primeira e mais respeitada foi a escola de Platão, defensora da teoria do mundo das idéias: as

\footnotetext{
${ }^{207}$ Para mais detalhes ver Descobrindo o Irã, op. cit., cap. "Encontrando Pasárgada".
} 
verdades são eternas e o homem pode reconhecê-las em si mesmo (...) Consideremos ainda o neoplatonismo, a influência aristotélica e a teologia acarita". ${ }^{208}$

De acordo com Mohammed Abed al-Jabri, em Introdução à Crítica da Razão Árabe, toda a atividade dos filósofos muçulmanos está voltada à problemática da conciliação entre razão e transmissão, onde a razão tem origem na filosofia grega e a transmissão no pensamento religioso islâmico, que se relaciona com a identidade cultural islâmica. Para o autor, é preciso não cair na armadilha de pensar que a filosofia muçulmana é apenas uma filosofia grega escrita em caracteres árabes. Portanto, não se trata de uma repetição, mas de uma influência que nos permite trazer o pensamento de filósofos ocidentais, como os já citados, e fazermos correlações entre Ocidente e Ocidente no campo da ética.

O termo em árabe para significar filosofia é falsafa. Conforme Miguel Attie Filho, o nome não vem de nenhuma raiz da própria língua, mas é resultado da transcrição do termo de origem grega ${ }^{209}$. Independente da teologia e da mística islâmica, a falsafa tem como fonte de inspiração mais importante o pensamento de Aristóteles.

Como informa Attie Filho, os filósofos mais conhecidos da falsafa viveram entre os séculos VIII e XII . Os nomes mais importantes são Al Kindi, Al Farabi, Ibn Sina (Avicena) e Ibn Rushd (Averróis). Geograficamente, a falsafa não teve apenas um único centro irradiador. Avicena, por exemplo, nasceu e morreu na Pérsia (seu túmulo pode ser visitado na cidade de Ramadan) e teve na medicina e na filosofia sua maior

\footnotetext{
${ }^{208}$ In: João Silva de SOUZA. Religião e Direito no Alcorão. Lisboa: Editorial Estampa, 1986., p. 115.

209 Miguel ATTIE FILHO. “A filosofia que nasce escrita em árabe”. Biblioteca entre Livros, Ano I, no 3.
} 
produção. Entre os 276 títulos de que é autor, destaca-se $A$ Cura, onde alia o pensamento filosófico à prescrição médica.

Mas é Al Kindi quem dá sua contribuição, nos textos, para a reflexão sobre a verdade. Al Kindi viveu em Bagdá e pertence ao grupo dos grandes cientistas muçulmanos, tendo trabalhado com filosofia, astronomia e medicina, entre outras áreas. Na falsafa, escreve inspirado francamente em Aristóteles ao dizer que a verdade deve ser buscada onde estiver: "Grande deve ser, pois, nosso agradecidmento àqueles que trouxeram um pouco da verdade, tanto mais àqueles que nos trouxeram muito da verdade. (...) Nada se tornou desprezível pela verdade, ao contrário, pela verdade tudo se enobrece."

Ibn Rushd, ou Averróis, tem seu papel nesta análise por admitir o sufismo no âmbito da falsafa. Muçulmano nascido em Córdoba, foi quem comentou para o Oriente “a maior parte das obras de Aristóteles, com o objetivo de restituir o que acreditou ser o pensamento autêntico do filósofo grego."210 Averróis ficou conhecido no Ocidente como “O Comentador”. Embora, como já mencionado, a falsafa cresce independente da religião, Averróis foi contra a corrente ao desenvolver a tese "de que o texto sagrado possuiria dois níveis de compreensão: o sentido literal e o oculto.” O caráter exotérico encontrado em Averróis, a nosso ver, tem correspondência com o sufismo, doutrina islâmica alguma vezes citada por Kiarostami como inspiradora de sua obra.

Em muitos estudos sobre Kiarostami, inclusive no já citado livro de Jean-Claude Bernardet, a relação do diretor iraniano com a morte é estabelecida. A morte como temática, é mais explicitada em O Vento nos Levará e Gosto de Cereja. No primeiro,

\footnotetext{
${ }^{210}$ Idem, p. 29.
} 
uma mulher vai ser enterrada, no segundo, um homem providencia o espaço no qual quer ser enterrado. Acreditando que em Close-up Sabzian sofre uma morte metafórica (o personagem "morre" enquanto Sabzian para ser Makhmalbaf e morre quando desmarcarado "morre" enquanto Makhmalbaf), podemos introduzir o pensamento sufi para iluminarmos nossa análise.

Os mestres sufistas (ou sufis) pregam que os seus discípulos meditem sobre a morte, considerando-a tão capital quanto inescapável na vida de todos: "Eles ensinam que a morte está sempre à espreita, a todo momento, em qualquer lugar, e que é preciso antes surpreedê-la, não deixando que ela nos surpreenda (...) Ibn Arabi [século XIII] fala da importância de 'morrer antes de morrer'", 211

No artigo Foucault e a revolução iraniana: o jornalismo de idéias diante da “espiritualidade política”, de Norman Madarasz, o autor apresenta um esquema, a partir de Foucault, onde o desejo de morte pode ser entendido. Entre os itens levantados, está a aceitação anti-fragmentária da morte, que vem a ser “a aceitação revolucionária da morte como finalidade possível do agir de maneira ética num reconhecimento de um novo processo de subjetivação em sua extensão universal". ${ }^{212}$

\footnotetext{
${ }^{211}$ In: Mateus Soares AZEVEDO. Iniciação ao Islam e Sufismo, p. 52-53

212 In: Norman MADARASZ. Foucault e a revolução iraniana: o jornalismo de idéias diante da "espiritualidade política". Verso e Reverso- Revista da Comunicação da Unisinos. Ano XX - 2006/3 Número 45. Disponível em: http://www.versoereverso.unisinos.br/index.php?e=9\&s=9\&a=78. O texto analisa a posição de Foucault a partir de dois artigos deste, como correspondente do Corriere della Sera e o do Nouvel Observateur.
} 
$\mathrm{O}$ artigo trata da posição política de Foucault quanto aos acontecimentos da revolução iraniana e da aceitação da morte por parte dos militantes xiitas. Hussein Sabzian, naturalmente, não é um militante xiita em Close-up. Embora ele "incorpore" Makhmalbaf que foi, de fato, um militante xiita nos anos 70, Sabzian é um militante da sua história, da história de um despossuído, que acredita que o cinema pode fazer as pessoas sofrerem menos e que tem, no martírio do personagem de $O$ Ciclista, sua referência de cinema humanista. Sua "aceitação da morte" se estabelece no olhar resignado quando percebe a chegada da polícia na casa dos Ahankhah. Como se trata de uma representação daquele momento, nunca saberemos se a expressão de Sabzian era esta mesma, ou se ele ficou desesperado. Nunca teremos acesso à verdade daquele momento. O material que nos é dado, esta imagem resignada de Sabzian diante da morte “enquanto Makhmalbaf”, insere-se por certo no tema da morte na obra de Kiarostami. E a inevitabilidade está inserida, por sua vez, na doutrina sufi aceita por Averróis na falsafa.

A interrelação destes itens cria um emaranhado. Mas o importante, nesta teia, é não ignorarmos que os meandros sobre verdade e mentira a que submetemos Kiarostami nesta análise, estão inseridos em conceitos filosóficos cuja raiz é ocidental (grega). Porém, que os filósofos muçulmanos aos quais Kiarostami teve acesso são herdeiros desta filosofia e, como no caso de Averróis, ao traduzirem e interpretarem os gregos, acrescentaram concepções da religião (o sufismo) e tornaram o mundo das idéias mais complexo e ao mesmo tempo mais interpenetrável. 


\section{4 - Realidade em trânsito}

Conceitos como de factício auxiliam a pensar uma outra forma de ver Kiarostami, assim como Rûmî, as contribuições de Wittgeinstein e Jerry Kuehl. 
A mentira vista sob a perspectiva da filosofia islâmica (falsafa) e da filosofia ocidental (grega) foi aqui suficientemente explorada. Cabe ainda ressaltar que a expressão artifício foi usada como sinônimo de fictício e seu parônimo factício.

Os caminhos em ziguezague em Onde fica a casa do meu amigo e Através das Oliveiras; a casa de chá e os objetos que rolam em $O$ Vento nos Levará; o tubo de spray, o corte do som e as intervenções de Kiarostami durante o julgamento em Closeup encaixam-se nesta definição de factício, que encontra suporte também na descrição de Deleuze para o termo: “sempre uma cópia de cópia, que deve ser levada ao ponto em que muda de natureza e se reverte em simulacro". ${ }^{213}$

Para os objetivos desta tese, nossa hipótese é de que os conceitos de factício e fictio, este trabalhado quando citamos Carlos Ginzburg, nos auxiliam a pensar os procedimentos de Kiarostami. Embora, concluímos, nenhum destes termos e seus respectivos conceitos sirvam, isolada ou exclusivamente para definir Close-up. Nos parece que a "realidade em trânsito" nos filmes de Kiarostami requer a soma de todos os conceitos. Ela pode talvez dar conta com mais êxito da complexidade filosófica e da essência desse cinema que pratica a invenção do real.

Além disso, acreditamos que também pode ajudar uma proposição que envolva a idéia de iluminação difusa, poeticamente traduzida pela popular expressão francesa entre chien et loup. Referência ao por-do-sol, ao momento do dia que está entre o cão e o lobo, ainda não é noite, mas não é mais dia, entre chien et loup remete a uma

\footnotetext{
${ }^{213}$ In: Gilles DELEUZE, Lógica do sentido, p. 271.
} 
luminosidade intermediária, o lusco-fusco, a hora em que o tempo na terra fica em dúvida.

A idéia de sombra em relação a Close-up, filme que está entre ficção e documentário, entre fato e fantasia, ou seja, um filme que está entre alguma coisa, nos sugere o enigma do poeta Rûmî, que fala em estar além da dualidade: “(...)você está limitado pela dissonância do 'Eu' e 'Nós'. A razão de sua ruína é este triste dualismo". 214

O pensamento de Wittgenstein, mesmo que este esteja se referindo às formas de expressão, fala em sombra de maneira direta. "Imaginamos que a sombra é uma imagem cuja intenção não pode ser questionada, isto é, uma imagem que não temos que interpretar para compreendê-la." ${ }^{215}$ A sombra, Wittgenstein completa, é também uma "imagem por similaridade." E sem esta similaridade, a sombra perderia sua finalidade.

Esta discussão envolvendo a mistura dos gêneros ficção-documentário afeta igualmente às produções de TV. A inglesa Leslie Woodhead, ex-diretora da seção de docudrama da TV de Granada, coloca a questão de modo a dar continuidade aos conceitos que estamos levantando aqui, principalmente à idéia da sombra de Wittgenstein. Ela diz que seria útil pensar na forma que resulta destes dois gêneros como "um espectro que vem da reconstrução jornalística para dar relevância ao drama com infinitas graduações no caminho."216

\footnotetext{
${ }^{214}$ RÛMÎ, El Masnavi, op. cit.

${ }^{215}$ In: Ludwig WITTGENSTEIN, The Blue and Brown Books, p.36.

${ }^{216}$ Leslie Woodhead, "The Guardian Lecture: Dramatised Documentary", BFI, 19, may, 1981, citada por Alan ROSENTHAL. In: Why Docudrama? Fact-Fiction on Film and TV, p. XV.
} 
Na Inglaterra, o âmbito desta discussão questiona a importância das emissoras de TV investirem sempre em programas no gênero docudrama, onde o fatídico tema da família real inglesa é campeão. A controvérsia que confronta o próprio termo docudrama vem ganhando espaço no campo da televisão e da indústria cionematográfica. Afora refletir sobre o conceito do termo em si, tem se discutido se o docudrama é apenas entretenimento popular ou um poderoso espaço para a prática da mentira.

"Mentira", aliás, é a expressão usada por Jerry Kuehl no seu texto Lies about Real People, um dos capítulos do livro Why Docudrama? Ao citar os filmes Malcom X, A Lista de Schindler, Appolo 13, Ed Wood, Nixon, Forrest Gump (sic) e JFK, cujos personagens tiveram episódios de suas vidas remontados de forma ficcional (tal como Kiarostami fez com Sabzian e a família Ahankhah), Kuehl diz que:

(...) desde que todas estas produções contam mentiras sobre pessoas reais, a atual popularidade dos 'dramadocs' significa que mais do que nunca mentiras são contadas sobre mais pessoais reais ${ }^{, 217}$.

Antes de definir "mentira", Jerry Kuehl deixa claro o que entende por dramadoc. Segundo ele, o "dramadoc" contém distintas características, e que por isso ele não existe numa forma "pura". Kuehl lembra que um dos primeiros filmes a se enquadrar nesta categoria foi L'Assassinat du Duc de Guise, de 1907, baseado em uma história real de um episódio da história francesa. O problema da fidelidade dos detalhes envolvendo a ação principal - o duque sendo morto a punhaladas - nunca foi 
esclarecido e sempre restou o fato de que não só o cenário era falso, pois reconstruído, como as pessoas que representaram os personagens. No mesmo artigo, e depois de citar em comparação títulos como Apollo 13, Kuehl traz o exemplo, em princípio descabido, de Forrest Gump. Por acaso duas produções protagonizadas por Tom Hanks, o personagem Gump é resultado da mente de seus criadores (Winston Groom, autor do romance, e Eric Roth, autor do roteiro), pois nunca existiu um sujeito chamado Forrest Gump.

Nesta linha, Close-up está mais para Apollo 13, que reproduz a volta da espaçonave de mesmo nome à Terra, do que para Forrest Gump. No entanto, seguindo o raciocínio de Kuehl, ambos seriam dramadocs porque baseados em eventos verdadeiros, mas “eles nunca poderão mostrar eventos reais porque, se eles o fizessem, não haveria a necessidade deles" ${ }^{, 218}$. Desse modo, Kuehl questiona a existência de dramadocs e se pergunta: "se eles não existem, o que há de fato? Somente acontecimentos reais; em outras palavras, documentários mosca-na-parede"219.

Pois bem, Jerry Kuehl diz que este tipo de documentário trabalha com uma convenção, porque a mosca na parede é como a mosca real, "uma irritante distração", que funcionaria mais para falsificar do que para mostrar. A dificuldade adicional cresceria, segundo Kuehl, quando o significado dos episódios só se revela depois do evento em si. Ao desmontar o dramadoc como veículo de representação do real, Kuehl está dizendo por que acredita que eles contam mentiras, embora falem de pessoas reais. No seu raciocínio dedutivo, eles contam mentiras, porque não contam a verdade.

${ }^{217}$ Idem. In: Jerry KUEHL, "Lies about Real People", p. 119.

${ }^{218}$ Idem, p. 122. 
"Dizer de alguma coisa que essa dita coisa é um caso, quando ela é um caso, é dizer a verdade sobre ela. Dizer de alguma coisa que não é um caso que ela é um caso, ou dizer de alguma coisa que ela é um caso quando ela não o é, é mentir." 220

Omitir frases de um diálogo, para Kuehl, assim como inventar diálogos que jamais existiram, não é ali que reside o problema da mentira. Os filmes mentem uma vez que um fato, um episódio é transformado em filme, pois qualquer tentativa de reproduzir determinada experiência envolve a perpetração da fraude e da desonestidade.

Kuehl afirma que, "uma vez liberado da necessidade de dizer a verdade, imaginação e fantasia ganham seu reino livre". ${ }^{221}$ Os documentaristas, segundo Kuehl, estão limitados somente pela credulidade do público. E neste ponto nos referimos novamente à importância da expectativa do público de Kiarostami e do cinema iraniano exibido em festivais. Uma expectativa que leva à credulidade mesmo de platéias especializadas, como demonstramos no capítulo $O$ som que engana. Com isso, queremos enfatizar a força interrogativa em torno da verdade e da mentira, relembrando o que Kiarostami disse sobre a cena do julgamento: "reconstruímos uma grande parte do julgamento na ausência do juiz, o que constitui uma das maiores mentiras que jamais me permiti". 222

\footnotetext{
${ }^{219}$ Idem. Mosca-na-parede é o termo utilizado para definir o movimento do Direto, subgênero do documentário originado nos Estados Unidos com o filme Primárias (Primary, 1960), de Robert Drew, onde a câmera torna-se invisível, não interferindo na realidade.

${ }^{220}$ No original: "To say of something that it is the case when it is the case is to tell the truth about it. To say of something that is not the case that is the case, or to say of something that is the case when it is not the case is to lie". Idem, p. 123. (Tradução de Beatriz Fontana, doutora em Letras Universidade Federal do Rio Grande do Sul.)

${ }^{221}$ Idem, ibidem.

${ }^{222}$ Stéphane GOUDET, Positif, no ${ }^{\circ} 442$, p. 95, op. cit.
} 
15 - Considerações finais 
Traçando relações entre a estética e a ética, este trabalho analisou o filme Closeup, com foco nas cenas da falha do som e do julgamento, como pertencentes ao conteúdo objetivo e ao conteúdo estético, ambos a serviço da invenção do real.

O caráter objetivo do filme começa a se estabelecer na cena em que Kiarostami conversa com Sabzian na prisão e o corpo do diretor entra em quadro, como observamos no capítulo 8 . O encontro de Sabzian com Makhlmalbaf, quando Kiarostami corta o som, igualmente tem caráter objetivo, porque serve para ratificar sua relação com a realidade. Ou seja, a construção que poderia ser inventada até ali, de fato pretende flagrar a realidade, pois a entrada de Makhmalbaf reforça o fator documento. O indivíduo Makhmalbaf existe, ele é cineasta e tem existência nacional e internacional reconhecida. Esta entrada funciona como o carimbo representado pela imagem da rotativa, apenas que sem a carga de simbolismo desta. Makhmalbaf não "representa" Makhmalbaf e a realidade, ele é a realidade (ou o real, o que existe por si só). Sua figura poderia simplesmente não aparecer no filme, o encontro entre ele e o homem que se fez passar por ele poderia não ocorrer, mas com ele na tela Kiarostami garante ao filme a gramática documental.

O conteúdo estético aparece na mesma cena, representado pelo corte do som. Kiarostami intervém esteticamente como que para reafirmar: isto é um documentário do cinema direto, não interfiro na realidade; ou seja, não paro tudo e recomeço depois de consertar o som. Como este conteúdo estético não é o que parece, pois o som foi propositalmente cortado, ele ganha outro significado, que dá ao filme contornos de incertitude, termo de Laura Mulvey referido no capítulo 4, onde navegamos nossas hipóteses conceituais por expressões como sombra (Wittgeinstein) e entre chien et loup. 
Nossa proposição é de que há uma espécie de martírio no filme, que nos remete à Karbala, pois não bastou mostrar simbolicamente o real (a rotativa), foi preciso reiterálo através de um real ligado à corporalidade (Kiarostami e Makhmalbaf), ratificando o caráter documental.

Por outro lado, na cena em que Makhmalbaf aparece na tela, trata-se, também, de enganar o espectador e o próprio Makhmalbaf, que sabia estar sendo filmado (carregava microfone inclusive), mas não sabia que teria seu diálogo cortado. É onde entra de forma mais contundente a discussão ética, embora ela não possa ser dissociada do conteúdo objetivo e do estético.

O princípio estético é um princípio moral, já disse Roberto Rossellini, um dos pais do ne-realismo, escola que o cinema de Kiarostami dialoga. Rossellini afirmou que o neo-realismo era sobretudo uma posição moral em relação ao mundo. Dela, segue-se uma posição estética; mas o ponto de partida é moral."223 Esta idéia, pois, norteou a análise sobre Close-up/Kiarostami: sob a perspectiva moral/estética, deu-se ênfase aos procedimentos que escondem, subtraem, falseiam. Elementos estes que assumem correspondência com sua obra, na medida em que fazer filmes para Kiarostami é um imperativo moral. Seus personagens agem moralmente, estão circunscritos ao certo e ao errado. Do menino que fingia estar tirando fotos em uma câmera sem filme ( $O$ viajante), passando pelo estudante que não achava correto ficar com um caderno que não era seu (Onde Fica a Casa do Meu Amigo?), até o homem que não encontrava cúmplices para seu suicídio (Gosto de Cereja) e o homem que cometeu crime de falsa identidade (Close-up).

223 "Entretien avec Roberto Rossellini”. Cahiers du Cinéma, entrevista a François Truffaut e Maurice Schérer, jul de 1954, nº 37, pp. 1-13. 
O aspecto moral em Close-up é analisado por Robert Safarian no artigo publicado no Irã "Simple Minded Moralismo of a Warm and Human Cinema" ${ }^{224}$. Nele, Robert Safarian chega à conclusão, a que estamos de acordo, que existe uma moral ambígua no filme, que torna o julgamento do espectador em realação a Sabzian mais difícil. Chegando ao final, o público não sabe se Sabzian é um transgressor da lei simplesmente, um homem com profunda imaginação, ou um homem atuando pela devoção a Makhmalbaf e ao cinema. E esta ambigüidade, que enriquece a arte em seu conteúdo filosófico, seria para Safarian uma contradição se associada ao final feliz no encontro de Sabzian, Makhmalbaf e o senhor Ahankhah. O articulista iraniano entende que Kiarostami estaria respondendo às expectativas do público ocidental, que por sua vez estaria cansado da "atmosfera imoral" ${ }^{225}$ predominante nos filmes do Ocidente e espera por uma espécie de compensação. Neste ponto nos permitimos discordar de Safarian, pois o final feliz que ele enxerga em Close-up é apenas um final aberto: não sabemos o que vai acontecer a partir do momento que o senhor Ahankhah abre a porta para o verdadeiro e o falso Makhmalbaf. Kiarostami, que acabara de ser juiz no tribunal, aqui não nos revelou o julgamento do senhor Ahankhah para com Sabzian.

\subsection{Atitude documentária}

\footnotetext{
224 Robert SAFARIAN. "Simple Minded Moralismo of a Warm and Human Cinema". Film International, Vol. 7, n 4, pp. 62-66.

${ }^{225}$ Idem, p. 63.
} 
A discussão em torno da moral, diga-se, não vale apenas para o documentário, mas também para a ficção. Entretanto, é no cinema documental que a questão ética ganha outra dimensão. Não é à toa que o polonês Krzysztof Kieslowski abandonou o documentário por questionar seus limites éticos e abraçou a ficção. Não é à toa que Kiarostami resiste em chamar Close-up de documentário. Contudo, acreditamos ser menos importante enquadrar o filme neste ou naquele gênero, mas identificar nos procedimentos internos da narrativa a sinalização para a ficção ou a não-ficção. É Kiarostami quem diz que está fazendo cinema documental (cinema direto), quando corta o som de uma cena e é ele quem afirma estar operando no registro do realismo quando não entra (com o aparato do cinema) na casa dos Ahankhah, respeitando a lógica razão de que não poderia ter estado lá antes que Sabzian tivesse sido preso.

Com o suporte de diversos autores, de variadas linhas teóricas, acreditamos ter feito uma radiografia da estrutura de Close-up e, com isto, iluminado estudos sobre outros filmes de Kiarostami, bem como de outros diretores influenciados por ele. E acreditamos, ainda, que este trabalho seja uma contribuição à inesgotável discussão sobre a atitude documentária no cinema, seja no documentário propriamente, ou na ficção, ou em outras palavras, contribuído para a reflexão deste cinema híbrido, que emaranha fato e fantasia, que coloca a realidade em trânsito. Um cinema que não foge às implicações com a ética.

Esta tese, que une observação, intuição e elaboração, evidentemente não fecha o assunto. Faz, isto sim, um elogio a Descartes e a importância da dúvida: duvidar do que se vê na tela e duvidar até de conclusões sobre nosso objeto de pesquisa. Ou seja, enquanto o autor trabalha sua "atitude documentarizante", nós, espectadores e 
pesquisadores, trabalhamos a "atitude descrédito". Dito de outro modo, acionamos a suspensão do crédito, numa operação inversa a Coleridge.

O que não temos dúvida, e a defesa desta idéia certamente percorreu o trabalho, é quanto o cinema de Kiarostami, ao mesmo tempo em que representa um sopro de originalidade a cada filme, nos provoca. E neste sentido, uma aproximação final ainda é necessária, com a providencial ajuda de André Bazin. No seu livro sobre Orson Welles, Bazin diz que o diretor de Cidadão Kane (Citizen Kane, 1941), teve a intuição do plano-seqüência, sem ter, propriamente, inventado o plano-seqüência. Ele o aprofundou, o explorou com maestria.

Assim como Welles teve essa intuição, Kiarostami a teve ao blefar na cena do corte do som. Ou seja, não foi o primeiro a forjar defeitos técnicos num filme, mas foi o primeiro a sofisticar a opção num filme narrativo, fazendo-a a serviço de um estilo de cinema que busca um determinado real, um real que leva a sua assinatura. Um real que pode incomodar aos que o vêem como o produto de um incesto entre fato e fantasia. Mas que pode encantar aos que o vêem como um espírito elevado no reino da criação. Ou que pode causar as duas reações, como no nosso caso.

Youssef Ishaghpour, iraniano estudioso dos dois diretores, Welles e Kiarostami, afirmou que se Orson Welles é a modernidade cinematográfica, Kiarostami é a pósmodernidade:

A era de Welles terminou e hoje não se faz muita coisa que tenha a importância de Kiarostami. O cinema iraniano de maneira geral está para além da questão da modernidade: há sempre o debate sobre cinema, a 
realidade, o espectador. Mas para mim, entre os iranianos, alguém que cria uma escola e que é copiado pelos outros é Kiarostami, que, além de tudo, é um grande fotógrafo. ${ }^{226}$

\subsection{Máscara}

Por fim, nos permitimos trazer um elemento extra-fílmico para a análise, que pode soar como digressão, mas que serve ao nosso objetivo. Este insight nos ocorre após a leitura de uma entrevista de Jean-Claude Bernardet, onde uma afirmação sua chama a atenção: "Nós vivemos numa civilização que tem dúvidas quanto às suas imagens." 227 . A frase está deslocada de seu contexto (o contexto era a imagem e a religião), mas acionou a reflexão em torno da imagem do homem Kiarostami. E neste ponto, adotamos uma visão quadroscópica, que considera o contexto cultural de Kiarostami, os procedimentos estético-éticos de sua obra através de Close-up, as possíveis interpretações que ele provoca e também a persona que se projeta do homem Kiarostami.

Acreditamos que nem sempre a leitura limitada à imanência de um filme nos dá respostas. Ao nos atermos apenas ao que vemos na tela corremos o risco de ignorar por completo o que há por trás da imagem e, às vezes, o que há por trás é cabalmente importante para entendermos o que aparece na tela. Ao retrocedermos (ou entrarmos)

\footnotetext{
${ }^{226}$ WERNECK, Alexandre. Jornal do Brasil, "Várias obras em uma só", entrevista com Youssef Ishaghpour, Caderno B, p. 4.

${ }^{227}$ Álvaro MACHADO, "Cólera e ternura de Jean-Claude Bernardet". Trópico [online]. Disponível em: http://pphp.uol.com.br/tropico/html/textos/1615,1.shl
} 
para camadas intra-epiderme, corremos o risco de tatear no escuro, mas o risco é inerente à pesquisa. Tudo isto para nos referirmos aos óculos escuros que Kiarostami usa como uniforme, dos quais ele não gosta de falar e dos quais a imprensa evita falar porque não sabe o que dizer, ou quer simplesmente respeitar a individualidade, ou o direito dele de não falar.

Kiarostami não permite que vejam seus olhos sem a intermediação das lentes. Nem em entrevistas e ocasiões sociais, nem 10 on Ten, mais de uma hora falando para a câmera, supostamente revelando-se através de dez lições sobre seu cinema autoral. A propósito da filmagem de Lição de Casa (Mashq-e Shab, 1989), o diretor admitiu que deveria ter tirado os óculos, já que pretendia conquistar a confiança das crianças que entrevistava. Reconheceu que um par de óculos limita a visão: "A moldura de um óculos emoldura a visão e permite a quem olha reconhecer apenas um pedaço da vida. (...) A luminosidade escura pode facilmente fazer com que deixemos passar os detalhes escondidos na sombra". ${ }^{228}$

Isto nos permite afirmar que Kiarostami capta o mundo de forma filtrada. $\mathrm{E}$ assim como maquia a realidade ao transformar seus cenários, ao usar os óculos ele esconde seu defeito congênito (um olho um pouco caído, fora de lugar), que lhe daria uma imagem outra. O próprio diretor admitiu em uma entrevista que gostaria de ser diferente do que é. Respondendo a uma questão sobre a necessidade de Sabzian ser outra pessoa, Kiarostami disse: "Eu me recordo que muitas vezes fiz exatamente a

\footnotetext{
${ }^{228}$ In: Film International - Iranian Film Quarterly, “Abbas Kiarostami, Iranian Director”, Vol. 2, nº 4, 1994. p. 51.
} 
mesma coisa que Sabzian, isto significa que eu criei para mim uma falsa personalidade, porque eu não estava satisfeito com a minha personalidade aparente."229

A exibição do defeito o deixaria parecer algo que não lhe agrada? O deixaria fragilizado? É prudente entrar nesta análise? É científico? É aceitável?

A censura (crítica) que nos impomos de não invadir a pessoa do cineasta acontece por pudor, por excesso de delicadeza talvez. Mas se transgredíssemos essa postura, diríamos que sim, a persona Kiarostami pode ser associada às imagens que o cineasta Kiarostami produz, tanto quanto as opiniões que emite. Goffman lembra que a palavra "pessoa", em sua acepção primeira, queria dizer máscara.

Em certo sentido, e na medida em que esta máscara representa a concepção que formamos de nós mesmos - o papel que nos esforçamos por chegar a viver - esta máscara é o nosso mais verdadeiro eu, aquilo que gostaríamos de ser. ${ }^{230}$

Talvez se pensarmos em John Ford e seu tapa-olho (e mesmo Nicholas Ray e seu tapa-olho do final de carreira), podemos concluir que é uma questão de ironia do destino: o cineasta que enxerga pouco, que vê o mundo de forma parcial. Mas em Kiarostami, além do sentido óbvio de ocultamento e do mistério em torno de sua figura, há um outro sentido na elucubração. Somos levados a entender que ele vê o mundo menos claro (ao nos depararmos com as fotos mais antigas dele sabemos que as lentes não eram tão escuras, com o passar do tempo e da notoriedade elas foram escurecendo

\footnotetext{
${ }^{229}$ In:Hormuz KÉY, Le Cinéma Iranien: L'Image d'une Societé en Bouillonnement, op. cit, p. 165. ${ }^{230}$ In: Erving GOFFMAN, A Representação do Eu na Vida Cotidiana, op. cit., p. 27., citando Robert Ezra PARK, "Race and Culture" (Glencoe, III.: The Free Press, 1950), p. 249.
} 
mais). Isto, por um lado, não permite que o vejamos como ele é, por outro lado, sabemos que ele enxerga tudo diferente de nós. O mundo dele á mais dark.

Sua visão das coisas, somada à capacidade de imaginação e conseqüente manipulação de fatos, resultam num talento ímpar a serviço do cinema, cuja análise não se esgota aqui, nem agora.

A teia de referências que construímos não segue um perfil delimitado, mas no momento em que o trabalho chega ao final, é possível observar que elas podem ser vistas como uma massa una, que estabelece diálogo com estudos contemporâneos sobre cinema, com repercussão em outras áreas, como a filosofia. Substancialmente, estas referências correspondem aos nossos interesses teóricos. E, assim, todas as citações estão "a serviço" de um pensamento autoral que, naturalmente, deve encontrar outras correntes não necessariamente concordantes.

Encerramos como Orson Welles em F for Fake, chegando à conclusão que talvez o nome de um homem não signifique tanto (Sabzian ou Elmyr de Hory). Talvez um filme sobre um homem que se fez passar por outro não sigifique muito e devemos pensar que: "Nossos trabalhos em pedra, pintura e impressão são sólidos por algumas décadas ou um milênio ou dois, mas tudo finalmente se despedaçará, e o minério irá se desgastar na última cinza universal. Os triunfos e as fraudes, os tesouros e as falsificações. Um fato da vida é que nós vamos morrer." (Orson Welles, em F for Fake). Ou talvez seja mentira. 


\section{REFERÊNCIAS BIBLIOGRÁFICAS}

ABED AL-JABRI, Mohammed. Introdução à Crítica da Razão Árabe. São Paulo: Unesp, 1999. 
AL-KARADHAWI, Yossef. O Lícito e o Ilícito no Islam. São Bernardo do Campo: Centro de Divulgação do Islam para a América Latina, 1991.

ANSARI, Hamid. Le Recit de L'Eveil: Rétrospectif sur la vie idéologique-scientifique et politique de L'Iman Khoméiny. Tehran: Ed. Institut de la Rédaction et de la Publication des Oeuvres de L’Iman Khoméiny, Affair Internationales, 1996.

ARENDT, Hannah. Da Revolução. São Paulo: Ática, 1988.

ARISTÓTELES. "Poética”. In: Poética Clássica. Trad.: Jaime Bruna, Intr.: Roberto de Oliveira Brandão. São Paulo: Cultrix, 1981.

ATTIE, Miguel Filho. Os sentidos Internos em Ibn Sina (Avicena). Porto Alegre: Edipucs, 2000.

AUERBACH. Erich. Mimesis. São Paulo: Perspectiva, $4^{a}$ ed., 2002.

AUMONT, M. J. L'Analyse des Filmes. Paris: Ed. Nathan, 1998. . A Imagem. Campinas: Papirus, 1993. \& MARIE, Michel. Dicionário Teórico e Crítico de Cinema. Campinas, Papirus, 2003. 
AZEVEDO, Mateus Soares. Iniciação ao Islam e Sufismo. Rio de Janeiro: Nova Era, 1994.

AZIZA Mohamed. L'Image et l'Islam. Paris: Albin Michel, 1978.

BARTHES, Roland. Introdução à Análise Estrutural da Narrativa. Rio de Janeiro: Vozes, 1973.

BAUDRILLARD, Jean. Simulacros e Simulação. Lisboa: Relógio d’Água, 1991.

BAZIN, André. O Cinema - Ensaios. São Paulo: Brasiliense, 1991.

BENJAMIN, Walter. Reflexões Sobre a Criança, o Brinquedo e a Educação. São Paulo: Editora 34, 2004.

BESANÇON, Alain. A imagem proibida; uma história intelectual da iconoclastia. Rio de Janeiro: Bertrand Brasil, 1997.

BERNARDET, Jean-Claude. Caminhos de Kiarostami. São Paulo: Companhia das Letras, 2004.

. O Autor no Cinema. São Paulo: Brasiliense, 1994.

BLOOM, Harold. O Cânone Ocidental. Rio de Janeiro: Objetiva, 2001. 
BORDWELL, David, \& STAIGER, Janet \& THOMPSON, Kristin. El cine clásico de Hollywood - Estilo Cinematográfico y modo de producción hasta 1960. Barcelona: Paidós Comunicación, 1985.

BORDWELL, David. Narration in the Fiction Film. London: Routledge, 1985.

BRIONGOS, ANA M. Black on Black Iran Revisited. Melbourne: Ed. Lonely Planet, 2000.

BURCKHARDT, Titus. A Arte Sagrada no Oriente e no Ocidente - Princípios e Métodos. São Paulo: Attar Editorial, 2004.

BURCH, Noël. Práxis do Cinema. São Paulo, Perspectiva, 1992.

CANTO, Estela. Borges à contraluz. São Paulo: Iluminuras, 1991.

CASETTI, Francesco e CHIO, Federico di. Cómo Analizar Un Film. Barcelona: Paidós, 1991.

CHARDIN, Sir John. Traveles in Persia: 1673-1677. New York: Ed. Dover Publications, 1988.

CHELKOWSKI, Peter \& DABASHI, Hamid. Staging a Revolution: the art of persuasion in the Islamic Republic of Iran. New Yor, New York University Press, 1999. 
CLÉMENT, J.-F., BEAUGÉ, G. L'Image Dans le Monde Arabe. Paris: CNRS Éditions, 1995.

COMOLLI, Jean-Louis. Filmar para ver - Escritos de Teoría y crítica de cine. Buenos Aires: Simurg/Cátedra La Ferla, 2002.

CORÃO. Tradução do Sentido do Nobre Corão para a Língua Portuguesa. Nasr, Helmi (trad.). Al Madinah Al-Munawarah: King Fahd Holy Quran Printing Complex, 2006.

DABASHI, Hamid. Close Up Iranian Cinema - Past, Present and Future. London: Ed.Verso, 2001.

DA-RIN, Silvio. Espelho Partido. Rio de Janeiro: Azougue Editorial, 2006.

DELEUZE, Gilles. Lógica do sentido. São Paulo: Perspectiva, 1974.

Diccionario de la Lengua Española - Real Academia Española (DRAE), edición en CDROM (22 ed.) - ESPASA-CALPE, S.A., Madrid, 2003.

DOSTOIÉVSKI, Fiódor. Os Demônios. São Paulo: Editora 34, 2004.

DUBOIS, Philippe. Cinema, Video, Godard. São Paulo: Cosac Naify, 2004.

EGAN, Eric. The films of Makhmalbaf - Cinema, Politics \& Culture in Iran. Washington: Mage Publishers, 2005. 
ELENA, Alberto. Los Cines Periféricos - África, Oriente Médio, India. Barcelona: Ed. Paidós Studio, 1998.

. Abbas Kiarostami. Madrid, Cátedra, 2002.

FABRIS. Mariarosaria. O Neo-Realismo Cinematográfico Italiano. São Paulo: Edusp, 1996.

FERDOWSI. Shahnameh: The Epic of the Kings. Trad.: Reuben Levy. Tehran: Ed.Yassovoli Publications, 2001.

FERREIRA, Francirosy Campos Barbosa. Imagem Oculta - Reflexões sobre a relação entre muçulmanos e a imagem fotográfica, 2001. 153 p. Dissertação (Mestrado em Antropologia Social) USP. São Paulo.

FOUCAULT. Michel. A Ordem do discurso. São Paulo: Loyola, 2006.

GAINES, Jane \& RENOV, Michael (org). Collecting Visible Evidence. Minneapolis: University of Minnesota, 1999.

GAUTHIER, Gauthier. Le Documentaire, un Autre Cinema. Paris, Nathan, 1995.

GENETTE, Gérard. Figures III. Discours du récit-essai de méthode. Paris, Seuil, 1972. 
GHANI, Cyrus. Iran and the Rise of Reza Shah: From Qajar Collapse to Pahlavi Power. Londres: Ed. I.B. Tauris Publishers, 2000.

GINZBURG, Carlo.Olhos de Madeira. São Paulo: Companhia das Letras, 1998.

GOFFMAN, Erving. A Representação do Eu na Vida Cotidiana. Petrópolis: Vozes, 1999.

GRODAL, Torben. Moving Pictures. New York: Oxford University Press, 1997

HABERMAS, Jürguen. A Ética da Discussão e a Questão da Verdade. São Paulo, Martins Fontes, 2004.

HAFEZ. A Fine Selection of Hafiz's Poems. Trad.: Hermann Nickbell. Tehran: Ed. Mirdashiti Farhang Sara, 2000.

HAGHIGHAT, Mamad. Histoire du Cinéma Iranien - 1900-1999. Paris: Ed. Bibliothéque Publique d'Information/Centre Georges Pompidou, 1999.

HAMIDULLAH, Mohammad. Introdução ao Islam. São Bernardo do Campo: Ed. Alvorada, s/d.

HOBSBAWN, Eric \& RANGER, Terence (org). A Invenção das Tradições. Rio de Janeiro: Paz e Terra, 1984 
HUIZINGA, Johan. Homo Ludens - O jogo como elemento da cultura. São Paulo: Perspectiva, 1971.

ISHAGHPOUR, Youssef. Le Réel, face et pile. Le cinéma d'Abbas Kiarostami. Tours: Farrago, 2000.

ISSA, Rose e WHITAKER, Sheila. Life and Art: The New Iranian Cinema. London: Ed. National Film Theatre, 1999

JOMIER, Jacques. Islamismo História e Doutrina. Petrópolis: Vozes, 1993.

KAHTALIAN, Marcos. Cinema Fundamentalista: O Cinema Iraniano Após a Revolução Islâmica., 2001. Dissertação (Mestrado em Multimeios) Instituto de Artes da Unicamp. Campinas.

KATZ, Ephraim. The Film Encyclopedia. Nova York: HarperCollins, 1994.

KAYYAM, Omar. Rubáiyát. Edição bilingüe inglês/português.Pioneira Editora, s/d. KEPEL, Gilles. Jihad - Expansão e declínio do islamismo. Rio de Janeiro: Biblioteca do Exército Editora, 2003.

KÉY, Hormuz. Le Cinéma Iranien: L'Image d'une Societé en Bouillonnement. Paris: Ed. Éditions Karthala, 1999. 
KIAROSTAMI, Abbas \& ISHAGHPOUR, Youssef. Abbas Kiarostami - Duas ou três coisas que sei de mim. O real, cara e coroa, São Paulo: Cosac Naify, 2004.

KHAMENE'I, Sayyid Ali Hosseini. Replies to Inquiries About Practical Laws of Islam. Tehran: Islamic Culture and Relations Organization Publication Department, 1997.

KOSSOY, Boris. Fotografia \& História. 2 ed. São Paulo: Ateliê Editorial, 2003.

KRÜGER, Irmtraud Tarr. Da Impossibilidade de Viver Sem Mentir. São Paulo: Pensamento, 1997.

LABAKI, Amir. É tudo verdade - reflexões sobre a cultura do documentário. São Paulo: Francis, 2005.

LEITE, Sidney Ferreira. O Cinema manipula a realidade? São Paulo: Paulus, 2003.

LEWIS, Bernard. O Oriente Médio. Rio de Janeiro: Jorge Zahar, 1996.

LIAÑO, Ignácio Gómez de. La Mentira Social - Imagens, Mitos y Conducta. Madrid: Tecnos, 1989.

MACDOUGALL, David. Transcultural Cinema. Princeton, Princeton University Press, 1998. 
MAKHMALBAF, Mohsen. The Day I Became a Woman. Tehran: Rowzaneh Kar, 2000.

MANESH, Mahboob (Org.). Iranian New Cinema. Tehran: Farabi Cinema Foundation, 1998.

MACKEY, Sandra. The Iranian - Persia, Islam and the Soul of a Nation. New York: Ed. Plume, 1996.

MADSEN, Roy Paul. Working Cinema Learning from the Masters. Belmont: Wadsworth, 1990.

METZ, Christian. Le Signifiant Imaginaire: psychanalyse et cinema. Paris: Union générale d'éditions, 1977.

MEDEIROS, Rui. A Revolução dos Turbantes. Rio de Janeiro: Civilização Brasileira, 1981.

MITCHELL, W.J.T Icology - Image, Text, Ideology. Chicago: Ed. The University of Chicago Press, 1986.

MONTESQUIEU, Charles-Louis de Secondat, baron de da Brède et de. Cartas Persas.

(Trad. Renato Janine Ribeiro). São Paulo: Paulicéia, 1991.

NAVE, Marco Della. Abbas Kiarostami. Milán: Il Castoro, 2003. 
NANCY, Jean-Luc. L'Évidence du film. Abbas Kiarostami. Bruxelas: Yves Gevaert Éditeur, 2001.

NESS, Richard R. From Headline Hunter to Superman - A journalism Filmography. Lanham: The Scarecrow Press Inc. Lanham, 1997.

NICHOLS, Bill. Representing Reality - issues and concepts in documentary.

Bloomington, Indiana University Press, 1991.

Introdução ao documentário. Campinas: Papirus, 2005.

ODIN, Roger. De la fiction. "Lettres d'amour en Somalie". Bruxelles: De Boeck Université, 2000.

O’SHEA, Maria. Culture Shock! Iran: A Guide to Customs and Etiquette. Portland: Graphic Arts Center, 1999.

PAMUK, Orhan. O Castelo Branco. Rio de Janeiro: Record, 1993.

PEREZ, Gilberto. The material ghost - Films and their médium. Baltimore: The John Hopkins University Press, 1998.

PINTO, Ivonete. Descobrindo o Irã. 2. ed. Porto Alegre: Ed. Artes e Ofícios, 1999. 
. A Dramatização no telejornalismo. Dissertação (Mestrado em

Comunicação). PUCRS. Porto Alegre, 1997.

PUENTE, Fernando Rey (Org.). Os filósofos e a mentira. Belo Horizonte: Editora UFMG, 2002.

ROSCOE, Jane \& HIGHT, Craig. Faking it - Mock-Documentary and the Subversion of Factuality. Manchester: Manchester University Press, 2001.

RUMI, Aidah (Trad.). Os Princípios Islâmicos. (s/ local):Ahlul Bait do Brasil, 1997.

RÛMÎ, Jalalud-din. El Masnavi. Barcelona: Edicomunicación, 1998

RUSSEL, Catherine. Experimental Ethnography. London: Duck University Press, 1999.

SAEED-VAFA, Mehrnaz \& ROSENBAUM, Jonathan. Abbas Kiarostami Contemporary film directors. Champaign: University of Illinois Press, 2003.

SAID, Edward. Orientalismo - O Oriente como Invenção do Ocidente. São Paulo: Companhia das Letras, 2001.

SARLO, Beatriz. Tempo Passado. São Paulo: Companhia das Letras, 2007.

SCHUON, Frithjof. Para compreender o Islã - Originalidade e universalidade da religião. Rio de Janeiro: Nova Era, 2004. 
SHAFII, Rouhi. Scent of Saffron-Three Generation of a Iranian Family. Londres: Scarlet Press, 1997.

SOUZA, João Silva de. Religião e Direito no Alcorão. Lisboa: Editorial Estampa, 1986.

SREBERNY-MOHAMMADI, Annabelle e MOHAMMADI, Ali. Small Media, Big Revolution: Communication, culture, and the Iranian Revolution. Minneapolis:University of Minnesota, 1994.

TAPPER, Richard. The New Iranian Cinema - Politics, Representation and Identity. Londres: I.B.Tauris, 2002

THOMPSON, Kristin. Storytelling in the New Hollywwod - Unterstanding Classical Narrative Technique. Cambridge: Harvard University Press, 1999.

THORAVAL, Yves. Les Cinémas du Moyen-Orient: Iran-Égypte-Turquie. Paris: Éditions Séguier, 2002.

TOLEDO, Dionísio de Oliveira, Org. Teoria da Literatura - Formalistas Russos. Porto Alegre: Ed. Globo, 1973.

VANOYE, Francis e GOLIOT-LÉTÉ, Anne. Ensaio Sobre a Análise Fílmica. Campinas: Papirus, 1994. 
VIROLLEAUD, Charles. Le Théâtre Persan ou Le Drama de Kerbéla. Paris: Librarie D’Amérique et D'Orient Adrien-Maisonneuve, 1950.

VOGLER, Christopher. A Jornada do Escritor. Rio de Janeiro: Ampersand, 1992.

ROSENTHAL, Alan (org.). New Challenges for Documentary. [Cap. "Documentaire: I think we are in trouble", de Brian Winston]. Berkeley: University of California Press, 1988.

(org.) Why Docudrama? Fact-Fiction on Film and TV.

Carbondale: Southern Illinois University Press, 1999.

XAVIER, Ismail. O Olhar e a Cena, São Paulo: Cosac \& Naify, 2003.

(org). A Experiência do Cinema, São Paulo: Graal, 2003.

. O Discurso Cinematográfico - A Opacidade e a Transparência. São

Paulo: Paz e Terra, $3^{\mathrm{a}}$ ed., 2005.

YOSHIDA, Kiju. O Anticinema de Yasugiro Ozu. São Paulo: Cosac \& Naify, 2003.

YOEL, Gerardo (org.). Pensar el cine 1 - Imagem Ética e Filosofia. Buenos Aires, Manantial, 2004. 
WEIS, Elizabeth e BELTON, John. Film Sound: Theory and Practice. New York: Columbia University Press, 1985.

WINSTON, Brian. Lies, Damn Lies and Documentaries. London: British Film Institute, 2000.

WITTGENSTEIN, Ludwig. The Blue and Brown Books. New York: Harper Torchbooks, 1965.

\section{Periódicos:}

ABEDI, Mehdi. \& FISCHER Michael. "Revolutionary Posters and Cultural Signs", Middle East Report, $\mathrm{n}^{\mathrm{o}}$ 159, jul-ago, 1989.

ATTIE FILHO, Miguel. “A filosofia que nasce escrita em árabe”. Biblioteca entre Livros, Ano I, no 3 .

BAECQUE, Antoine de. "Le réel a tremblé". Cahiers du cinéma, nov, no 461.

BERGALA, Alain. "Les pleins pouvoirs du cinéma", Cahiers du Cinéma, edição especial Cannes 2004, mai, 2004.

BAUDRY, Jean-Louis. “Le Dispositif: Approches métapsychologiques del'impression de réalité", Communications, $\mathrm{n}^{\circ}$ 23, 1975. 
BLOUIN, Patrice \& TESSON, Charles. "Ten - Elimination de 1'auteur". Cahiers $d u$ Cinéma, $\mathrm{n}^{\mathrm{o}}$ 571, set 2002.

BRUM, Eliane. Qual é a do jornalismo literário? Caderno Cultura, Zero Hora, 28, out, 2006, p. 7.

CATANI, Afrânio Mendes...[et al.] (org.). "O cinema inverdade de Kiarostami”, Ivonete PINTO. Socine - Estudos de Cinema Ano V. São Paulo: Panorama, 2003.pp. $320-328$.

CIMENT, Michel \& GOUDET, Stéphane. "Entretian avec: Kiarostami: Um approche existencialiste de la vie”, Positif, nº 442, dez, 1997.

. "Entretian: Abbas Kiarostami - Des femmes

réelles et non de cinema". Positif, n 499, set 2002

COMOLLI, Jean-Louis. "L'anti spectateur, sur quatre film mutants". Images Documentaires. Association Images Documentaires, Paris, $\mathrm{n}^{\mathrm{o}} 44,1^{\mathrm{o}}$ e $2^{\mathrm{o}}$ semestres 2002.

FABRIS, Mariarosaria (Org). "De Hafez a Makhmalbaf - A influência da literatura no cinema iraniano", Ivonete PINTO. III Encontro Socine - Sociedade Brasileira de Estudos de Cinema . III Estudos de Cinema. Porto Alegre: Sulina, 2003. 
Film International - Iranian Film Quarterly. “Abbas Kiarostami, Iranian Director". Vol. 2, nº 4, 1994.

. "Debates with Abbas Kiarostami - Iranian

Movie Director". Vol. 3, nº 1, 1995.

GIOVANNI, Janine Di. “Reaching for Power”, National Geographic, jun., 2004.

GIRON, Luis Antônio. “Jean Baudrillard: A verdade oblíqua”. Revista Época, 7 jun, 2003.

GOUDET, Stéphane. "Entretien avec Kiarostami: manipulations”, Dossier Kiarostami, Positif, 442, dez, 1999.

. “Abbas Kiarostami - Les yeux du coeur”. Positif, 466, dez, 1999,

“Kiarostami Le magnifique”. Cahiers du Cinéma, no 493, ago, 1995.

Abbas KIAROSTAMI. “A arte da inadequação”, Folha de São Paulo, Caderno Mais, 17 out, 2004.

MACHADO, Rubens Jr. ...[et al.] (org.). "Realismo e histórias mínimas no novo cinema argentino", Ivonete PINTO. VII Estudos de Cinema - SOCINE. São Paulo: Annablume, 2006, v. VII, p. 85-92 
MASONI, Tullio. “Close Up”, Cineforum, n 333, mar, 1994.

MENEZES, Paulo. "Representificação - As relações (im)possíveis entre cinema documental e conhecimento". Revista Brasileira de Ciências Sociais, Vol. 18, n 51, fev, 2003.

MOCARZEL, Evaldo. “A Palavra no Documentário”. Revista Cinemais - Especial: Documentário, no 36, out-dez, 2003.

MULVEY, Laura. “Kiarostami's Uncertainty Principle”. Sight and Sound, vol. 8, $\mathrm{n}^{\mathrm{o}}$ 6, jun, 1998.

NINEY, François. "Gros plan sur Close-up - Kiarostami, le passeur”. Cahiers $d u$ cinéma, $\mathrm{n}^{\circ}$ 450, dez, 1991.

PASOLINI, Pier Paolo. "A poesia do nôvo cinema". Revista Civilização Brasileira, ano I, nº 7, maio, 1966. Rio de Janeiro: Editora Civilização Brasileira, 1966, p. 279.

PINTO, Ivonete. "Baran Vence o Festival de Cinema do Irã". Folha de São Paulo, 12, fev 2001. 
. "Na periferia do cinema". Revista Teorema - Crítica de Cinema, $\mathrm{n}^{\mathrm{o}}$

1, ago 2002.

. "Os mestres e seus princípios" e "O Princípio da Imagem".

Teorema-Critica de Cinema, no 6, dez 2004.

. "Em busca de um cinema distinto". Teorema Crítica de Cinema, $\mathrm{n}^{\circ}$

5, ago 2004.

. “Um Close em Bollywood”. Revista Arquipélago, no 4, dez 2006.

RIBEIRO, Renato Janine. "Filósofos examinam o direito de mentir". Folha de São Paulo-Jornal de Resenhas, 9 ago, 2003.

SAFARIAN. Robert. "Simple Minded Moralismo of a Warm and Human Cinema". Film International - Iranian Film Quarterly, Vol. 7, nº 4, 2000.

SAMINI, Naghmeh. "Once Upon a Time...Literary Adaptations in Iranian Cinema". Film International - Iranian Film Quarterly, Vol. 5, nº 25, 1999.

Schérer, MAURICE \& TRUFFAUT, François. "Entretien avec Roberto Rossellini”. Cahiers du Cinéma, no 37, jul 1954.

VERISSIMO, L.F. "Show”. Zero Hora, no. 15195, 5 abr, 2007. 
Teorema Crítica de Cinema. “O Cinema e a Memória”, nº 7, ago 2005.

. "Intuição e sensibilidade", n 8, dez 2005.

TESSON, Charles. "Gros plan sur Close-up - Body Double". Cahiers du cinéma, no 450, dez 1991.

WERNECK, Alexandre. Jornal do Brasil, "Várias obras em uma só", Caderno B, p. 4, 20/05/2001.

WOLFE, Tom. Radical Chique e o Novo Jornalismo. São Paulo: Cia. das Letras, 2005.

\section{Internet:}

AL ISLAM. Kingdom of Saudi Arábia Ministry of Islamic Affairs, Endowments Da'wah and Guidance. Disponível em <http://www.al.islam.com>

ALBORNOZ, Suzana Guerra. Trabalho e utopia na modernidade . Disponível em $<$ http://www.unisc.br/cursos/graduacao/filosofia/docs/trabaho_utopia.pdf $>$ Acesso em 5 maio 2006.

ALJARILLA Rubén García. Abbas Kiarostami. Disponível em $<$ http://www.comunicacionymedios.com> Acesso em 17 jun 2007. 
AZEVEDO, Tatiana. Cinema Ensaio - Entrevista com Jean-Claude Bernardet, publicada na revista Bravo [online]. Disponível em <http://www bravonline.com.br/noticias.php?id=1966> Acesso em $1^{\circ}$ maio 2006.

FONSECA, Rodrigo. O inconformista - Entrevista com Jean-Claude Carrière, publicada no jornal O Globo 11/04/2006 - Segundo Caderno. Disponível em $<$ http://blackandwhiteincolor.blogspot.com/2006/04/jean-claude-carrire-oinconformista.html> Acesso em 22 abr. 2006.

COBRA, Rubem Q. Gobineau. Filosofia Contemporânea, Brasília, 2001. Disponível em <http://www.cobra.pages.nom.br/fc-gobineau.html> Acesso em 20 mai. 2006.

DERRIDA, Jacques. História da mentira: prolegômenos. Estud. av. [online]. mayo/ago. 1996, vol.10, no.27 [citado 24 Mayo 2006], p.7-39. Disponível em: $<\mathrm{http} / /$ www.scielo.br/scielo.php?script=sci_arttext\&pid=S0103$40141996000200002 \& \operatorname{lng}=\mathrm{es} \& n r m=$ iso $>$. Acesso em: 24 mai. 2006.

INTERNATIONAL Journal of Middle East Studies. Disponível em: $<$ http://www.jstor.org $>$

IZQUIERDO, Ivan \& CAMMAROTA, Martín. Trends in Neurosciences, set. 2006. Disponível em: <http://www.trends.com/tins> . Acesso em 18 de jan. 2007. . Neuron, jan. 2007. Disponível em: www.neuron.org. Acesso em 18 de janeiro 2007. 
LEVIEUX Michele. Journal L'Humanité, 19 mai 2004. Disponível em: <http://www.humanite.fr/journal/2004-05-19/2004-05-19-393994>. Acesso em 3 fev. 2006.

MACHADO, Álvaro. “Cólera e ternura de Jean-Claude Bernardet”. Trópico [online]. Disponível em: <http://pphp.uol.com.br/tropico/html/textos/1615,1.shl>. Acesso em 8 fev 2005.

MADARASZ, Norman. Foucault e a revolução iraniana: o jornalismo de idéias diante da "espiritualidade política". Verso e Reverso - Revista da Comunicação da Unisinos. Ano XX - 2006/3 - No 45. Disponível em: $<$ http://www.versoereverso.unisinos.br/index.php?e=9\&s=9\&a=78>. Acesso em 10 set. 2006.

NG, Daniel. "Noises Off: Seeking Solace in the Ambient Sounds of the City". Village Voice [online]. Disponível em: < htt://www.villagevoice.com/film/0413,ng,52198,20.html>. Acesso em 02 set.2006.

PARHAMI, Sharin. Iranian Cinema: Before the Revolution. Revista Off Screen, dez. 1999. Disponível em: <http://www.horschamp.qc.ca/now-offscreen/preiran>. Acesso em 13 set. 2000 .

RIGGINS, Stephen. "Silêncio, sexo e verdade - Uma entrevista com Michel Foucault" . Toronto, 22 de jun de 1982. Traduzido a partir de Michel FOUCAULT, Dits et Écrits. 
Paris: Gallimard, 1994, Vol. IV, pp. 525-538, por Wanderson Flor do Nascimento. Disponível em: <http://www.unb.br/fe/tef/filoesco/foucault/silence.html>. Acesso em 27 set. 2006.

ROSENBAUM, Jonathan. Makhmalbaf and Dostoievsky: A Limit Comparison. Bulletin of The 10th Festival of Film from Iran by Center of Chicago, Chicago, out. 1999. Disponível em: <http://www.webmemo.com/iran/articleview>. Acesso em 13 set. 2000.

SARAIVA, Vladimir Sosa. Los Medios, La Réplica y los Completos. Los Documentalistas, Buenos Aires. Ano 1, n², ago. 2005. Disponível em $<$ http://www.documentalistas.org.ar/notaboletin.shtml?sh_itm=b8de57ff60833ca12c409 09476c25d82>. Acesso em 12 nov. 2005.

SCOTT, A.O. “The Road to Guantánamo' Offers Grim Chronicles That Anger and Stir", The New York Times [online] $<$ http://movies2.nytimes.com/2006/06/23/movies/23guan.html?th\&emc=th $>$ Acesso em 23 jun. 2006

TRACINSKI, Robert. The Fundamentalist Threat. Creators Syndicate. Set. 2001. Disponível em: <http://www.aynrand.org/medialink/columns/rt111201.shtml>. Acesso em 22 mar. 2002. 
A week with Kiarostami, de Yuji Mohara (1999, 90')

Documentário “Abbas Kiarostami. La leçon de Cinéma, Le Vent Nous Emportera”, de Mojdeh Famili (52’) (In: Kiarostami, Abbas. Le vent nous emportera, DVD, Paris)

10 on Ten, de Marin Karmitz e Abbas Kiarostami (2004, 87’) (DVD, Paris)

Close-up Long Shot, de Moslem Mansouri \& Mahmoud Chokrollahi (1996, 60') (In: Makhmalbaf, Moshen. DVD Salam Cinema, Paris)

Il giorno della prima de Close-up, de Nanni Moretti (1996, 6’48)

Friendly Persuasion: Iranian Cinema After the Revolution, "Kiarostami Interview", de Jamsheed Akrami (2000, 113')

\section{Anexos:}

\section{Descrição comentada do filme Close-up Long Shot, de Moslem}

Mansouri e Mahmoud Chokrollahi, de 1996.

Em depoimento para o documentário sobre Close-up Long Shot, amigos e vizinhos dizem que Sabzian sempre aparecia com roteiros embaixo do braço. Era muito ligado em cinema, só falava disto. Estes amigos afirmam não saber o que significa “close-up", arriscam que pode significar "sujo". 
Os amigos e vizinhos falam do que acharam do filme, que fez sucesso, chegando até a passar na TV. A maior parte condena o que Sabzian fez, mas procura compreender o gesto.

Sabzian era casado e tinha dois filhos. Depois de desempregado, a mulher pediu o divórcio, ele ficou com um dos filhos para criar, ajudado pela mãe, com quem morava. Mais tarde o segundo filho acabou ficando também com a mãe de Sabzian. Sabzian ia e vinha, nunca conseguiu ganhar a vida e "um homem precisa trabalhar", diz um dos amigos de Sabzian. Outro completa: “Um tipo simpático, mas não muito normal. Ele mente, fabula, sonha. As pessoas o deixam falar sem levá-lo a sério”. (Neste momento, Sabzian entra em cena pela primeira vez. Notamos que envelheceu muito desde Close-up. Aparenta mais de 50 anos - ele tem 42, nasceu em 1954, está mais magro). Sabzian, ao que parece, ouve a frase através de um vídeo, pois o depoimento teria sido gravado anteriormente. Sabzian então se defende: "Me vêem assim porque meus sonhos não foram realizados, porque eu não correspondo às normas sociais".

A câmera mostra onde Sabzian vive: uma casa cuja porta está fechada com um fio de náilon. Ou seja, o filme/sucesso não mudou a vida miserável dele. Aparecem na sala franciscana fotos nas paredes. O tema é Close-up. Começa a falar da primeira cena do filme, do encontro no micro ônibus. Sabzian comenta: quando eu disse àquela senhora que eu era o autor do livro (Sabzian estava lendo o roteiro de O Ciclista), eu era Makhmalbaf, me deu prazer. Quando o filme acabou e foi exibido, nas ruas me lançavam olhar desaprovador. Isto se deve ao espírito estreito deles.

A farsa com a família Ahankhah durou 4 dias. "Eu penso em Orson Welles quando ele dava conselhos aos estudantes que perguntavam como era possível conseguir dinheiro para fazer um filme, Welles respondia: roube! 
No depoimento de um ex-patrão (um tipo que parece que parece bem sucedido), dono de gráfica: “ele só queria saber de cinema. Deixava de trabalhar para ir nos estúdios pedir autógrafo dos artistas. Sabzian perdeu tudo, abandonou família e trabalho por amor ao cinema. Como um vício".

Este depoimento reforça a idéia que o documentário passa de que Sabzian é um ser doente. Um obcecado por cinema.

Sobre o tema proposto pelo documentarista intitulado "escroquerie", Sabzian diz: "todos foram escroques: o jornalista que com a reportagem queria ser Oriana Fallaci (isto está em Close-up, na cena do táxi, não é dedução de Sabzian) e o próprio Kiarostami, que explorou o filme, e se tornou mundialmente célebre". "Isto é um tipo de escroque”, acusa Sabzian, que continua: “a família queria fazer um filme e eu fingi que estava fazendo um. Mas o que aconteceu? Eles acabaram participando de um filme”.

Sabzian chama a atenção para o fato de que Kiarostami deu a ele o mesmo tipo de orientação que o próprio Sabzian deu à família quando ensaiava as supostas cenas do filme que dirigiria.

A irmã de Sabzian também dá depoimento sobre o filme: “É a versão de $O s$ Miseráveis, e meu irmão é Jean Valjean. Close-up não é um grande filme. Só mostra lados negativos, conflitos...”.

Sabzian define: "Para mim o filme tem o lado negativo e o lado positivo". E em meio à reiteração do discurso de "sou oprimido e não tenho voz" insiste na citação ao $O$ Ciclista, de Makhmalbaf: “Sou como Nassim. Quando não é mais preciso pedalar, eu pedalo, continuo pedalando". "Não há espaço para expressão de gente como Sabzian" (diz de si mesmo), e emenda: "Como eu. Sou como um cadáver na vertical”.

Em seguida fala de sua infância e conta uma história de humilhação: por ter entrado no cinema sem pagar (sempre a paixão pelo cinema), foi levado a um pátio, 
rodeado de crianças, e humilhado por um adulto, com as crianças em círculo rindo dele. "Maldito seja o cinema. O cinema roubou minha infância", sentencia Sabzian ao final.

\section{FILMOGRAFIA de Abbas Kiarostami como diretor:}

1. O Pão e o Beco (Nan va Kuche, Irã, 1970 - 35 mm, 11 min)

2. The Breaktime (Zang-e Tafrih, Irã, 1972, 35mm, $14 \mathrm{~min}$ )

3. The Experience (Tadjrebeh, Irã, 1973, 35mm, 56 min)

4. O Viajante (Mosafer, Irã, 1974, 35mm, $71 \mathrm{~min}$ )

5. Two Solutions for One Problem (Do Rah-e hal Bara-ye Yek Mas' aleh, Irã, $1975,35 \mathrm{~mm}, 5 \mathrm{~min})$

6. So I Can (Man ham Mitunam, Irã, 1975, 35mm, 4 min)

7. The Colours (Rang-ha, Irã, 1976, 16mm, 15min)

8. A Suit for Wedding (Lebosi bara-ye Arusi, Irã, 1976, 35mm, 53 min)

9. The Report (Gozaresh, Irã, 1977, 35mm, $105 \mathrm{~min}$ ) 
10. Tribute to the Teachers (Bozorgdasht-e mo'Allem, Irã, 1977, 16mm, $23 \mathrm{~min}$ )

11. How to Make Use of Our Leisure Time? (Az Oghat-e Faraghat-e Khod Chegouneh, Irã, 1999, 16mm, $7 \mathrm{~min})$

12. Estefadeh Konim?, Irã, 1977, 16mm, 23 min)

13. Solution $N^{o} .1$ (Rah-e Hal-e Yek, Irã, 1978, 16mm, 11min)

14. First Case, Second Case (Qaziyeh Shekl-e Avval, Qaziyeh Shekl-e Dovvum, Irã, 1979, 16mm, $53 \mathrm{~min})$

15. Toothache (Dandan-e Dard, Irã, 1980, 16mm, 24 min)

16. Orderly or Unorderly (Beh Tartib ya Bedun-e Tartib, Irã, 1981, 35mm, 16 min)

17. The Chorus (Hamsarayan, Irã, 1982, 35mm, $17 \mathrm{~min}$ )

18. Fellow Citizen (Hamshahri, Irã,1983, 16mm, 52 min)

19. First Graders (Avaliha, Irã, 1985, 16mm, 84 min)

20. Onde Fica a Casa do Meu Amigo? (Jane-ye dust koyast?, 1987, Irã, 35mm, 83 $\min )$ 
21. Lição de Casa (Mashq-e Shab, Irã, 1989, 16mm, 86 min)

22. Close-up (Nama-ye Nazdik, Irã, 1990, 35mm, 90min)

23. Vida e Nada Mais (A Vida Continua...) (Zendegi va Digar Hich, Irã, 1992, $35 \mathrm{~mm}, 91 \mathrm{~min})$

24. Através das Oliveiras (Zir-e Darakhatan Zeyton, Irã, 1994, 35mm, 103 min)

25. Lumière et Compagnie [episódio de filme coletivo] (França, 1995, 35mm, 52’’)

26. À propos de Nice, la suite [episódio de filme coletivo, segmento: Repérages] (França, 1995, 35 mm, $17 \mathrm{~min}$ )

27. Gosto de Cereja (Taam-e-Gilas, Irã, 1997, 35mm, 99 min)

28. O Vento nos Levará (Bad Maara Jahad Bord, Irã-França, 1999, 35mm, 118 $\min )$

29. ABC África (ABC Africa, Irã-França 2001, digital, $85 \mathrm{~min}$ )

30. Dez (Dah, 2002, Irã-França, digital, $91 \mathrm{~min})$

31. Five (Five, Irã-Japão-França, 2003, digital, 74 min) 
32. Dez sobre Dez (Ten on Ten, Irã-França, 2004, digital, 88 min)

33. Tickets (Tickets, dir.: Abbas Kiarostami, Ermanno Olmi e Ken Loach Itália/Inglaterra, 2005, $105 \mathrm{~min}$ )

34. Roads of Kiarostami (Irã-Coréia do Sul, 32 min, 2006)

35. Chacun son cinéma (Irã-França, 3min, 2007) (segmento "Where is my Romeo?")

36. Kojast jaye residant (2007) (em produção)

37. Certified Copy (Roonevesht barabar asl ast) (Irã-França, 2008) (em produção)

\section{FILMOGRAFIA de Abbas Kiarostami apenas como roteirista:}

The Key (Kelid) (1987) Dir.: Ebhahim Forouzesh,

The Driver (Ranandeh) (1980) Dir.: Naser Zara'ati.

The Look (Negah) (1984) Dir.: Ebrahim Furuzesh.

Class Bell, Recess Bell (Zang-e dars, Zang-e tafrih) (1984) Dir.: Iraj Karimi

The Moments (Lahzeh-ha) (1985) Dir.: Iraj Karimi 
I, Myself (Khodam, Man Khodam) (1985) Dir.: Ebrahim Furuzesh

The Key (Kelid) (1986). Dir.: Ebrahim Furuzesh.

The Wild Irises (Zanbaqa-haye vashi) (1989) Dir.: Ebrahim Furuzesh.

The Three Faces of a School Proctor (Seh Chehreh az yek mobser) (1989) Dir.: Hassan Aqa Karimi.

The White Balloon (Badkonak-e sefid) (1995) Dir.: Jafar Panahi

The Journey (Safar) (1995) Dir.: Ali-Reza Raisian

Willow and Wind (Bid o bad) (1999) Dir.: Mohammad Ali Talebi

Ouro Carmim (Talaye Sorkh) (2002) Dir.: Jafar Panahi

Men at Work (Kargaran mashghoole karand) (2006) Dir.: Mani Haghighi

\section{Outras funções:}

The Driver (Ranandeh) (1980) Dir: Naser Zara'ati. (roteirista/editor)

The Look (Negah) (1984) Dir: Ebrahim Furuzesh. (Editor)

Class Bell, Recess Bell (Zang-e dars, Zang-e tafrih) (1984) Dir: Iraj Karimi (Editor)

The Moments (Lahzeh-ha) (1985) Dir: Iraj Karimi (Editor)

I, Myself (Khodam, Man Khodam) (1985) Dir: Ebrahim Furuzesh (roteirista/editor) 
The Key (Kelid) (1986). Dir: Ebrahim Furuzesh. (roteirista/editor)

The Wild Irises (Zanbaqa-haye vashi) (1989) Dir: Ebrahim Furuzesh. (Editor)

2001: Para uma vídeo-instalação exibida na Bienal de Veneza, Kiarostami gravou um jovem casal dormindo, e projetou a imagem durante 100 minutos sob uma cama com travesseiros. 